\title{
Analysis of red spruce (Picea rubens) regeneration in Pocahontas, Randolph, and Tucker counties, West Virginia
}

Adam W. Rollins

West Virginia University

Follow this and additional works at: https://researchrepository.wvu.edu/etd

\section{Recommended Citation}

Rollins, Adam W., "Analysis of red spruce (Picea rubens) regeneration in Pocahontas, Randolph, and Tucker counties, West Virginia" (2005). Graduate Theses, Dissertations, and Problem Reports. 1616. https://researchrepository.wvu.edu/etd/1616

This Thesis is protected by copyright and/or related rights. It has been brought to you by the The Research Repository @ WVU with permission from the rights-holder(s). You are free to use this Thesis in any way that is permitted by the copyright and related rights legislation that applies to your use. For other uses you must obtain permission from the rights-holder(s) directly, unless additional rights are indicated by a Creative Commons license in the record and/ or on the work itself. This Thesis has been accepted for inclusion in WVU Graduate Theses, Dissertations, and Problem Reports collection by an authorized administrator of The Research Repository @ WVU. For more information, please contact researchrepository@mail.wvu.edu. 
Analysis of Red Spruce (Picea rubens) Regeneration in Pocahontas, Randolph, and Tucker Counties, West Virginia.

\title{
Adam W. Rollins
}

Thesis submitted to the Davis College of Agriculture, Forestry, and Consumer Sciences at West Virginia University in partial fulfillment of the requirements

for the degree of

\author{
Master of Science \\ In \\ Forestry
}
Ray R. Hicks, Jr., Ph.D., Chair James S. Rentch, Ph.D. David W. McGill, Ph.D.

Division of Forestry

Morgantown, West Virginia 2005

Keywords: red spruce, Picea rubens, regeneration, West Virginia 


\begin{abstract}
Analysis of Red Spruce (Picea rubens) Regeneration in Pocahontas, Randolph, and Tucker Counties West Virginia.

Adam W. Rollins
\end{abstract}

The red spruce forest type of eastern North America is a unique, remnant ecosystem from the last glaciations. The present-day stands represent the result of extended climate change, regional natural disturbances and intense anthropogenic influences. The red spruce forest type has considerable ecological and economical importance, despite a limited distribution. Studies have documented red spruce experiencing declining health, vigor, and radial growth as well as high mortality rates. As a result, the red spruce forests have been described as experiencing a forest decline. Pollution, biotic stresses, climate change and natural stand dynamics are some of the hypotheses advanced to explain this phenomenon, however to date no general consensus has been reached.

Three red spruce communities in the Central Appalachians of West Virginia were accessed temporally over a period of 10 to 11 years and by forest zones (i.e. hardwood, ecotone, red spruce zones). These communities experienced an increasing density of red spruce over time across all forest zones. Red spruce was successfully establishing and expanding across the ecotone into the hardwood forest zone. The greatest increase of red spruce was seen in the more disturbed and earlier successional sites, whereas the less disturbed red spruce community experienced the least change. The red spruce populations in this study were thriving and increasing the density of red spruce seedlings, advanced regeneration and trees across the sprucehardwood ecotone as well as under the surrounding hardwood canopy. Red spruce seedling densities were found to be greater with increased cover of bryophytes and coarse woody debris, while densities are reduced with increasing cover of Dryopteris spp. 


\section{Acknowledgments}

I thank Dr. Steve Adams of Dabney S. Lancaster Community College, Virginia and Dr. Steve Stephenson of the University of Arkansas for allowing me the opportunity to use their historical data in conjunction with the permanent study sites. Their generosity and professional careers have set the standard, which I strive to follow. I thank my wife, Virginia “Jenni” Rollins for her countless hours of fieldwork and moral support throughout the duration of this project. Jenni you kept me going even when I did not want to, thank you. Thanks are also extended to Dr. George Seidel for assisting me with various aspects of the statistical analysis. I thank my advisor Dr. Ray R. Hicks Jr., for taking me in, and giving me a chance to study forest ecology. You have mentored me both professionally and personally and I will continue to work up to your level of commitment and expertise. I thank my remaining committee members Dr. James Rentch and Dr. Dave McGill. I have enjoyed studying under you and getting to know you. Your commitment to research and excellence serves as an inspiration to me. Thank you for all your help, suggestions, and patience. 


\section{Table of Contents}

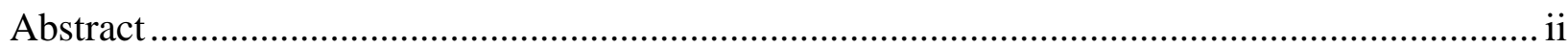

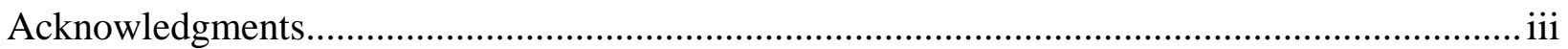

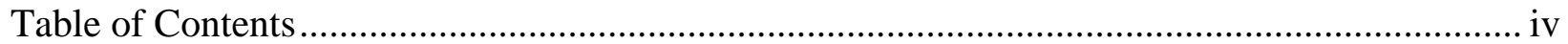

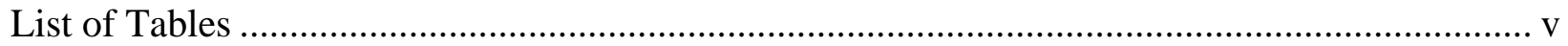

List of Figures ............................................................................................................... vi

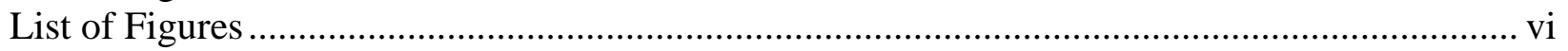

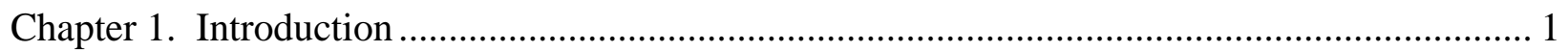

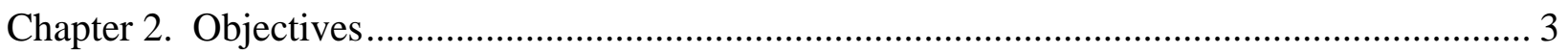

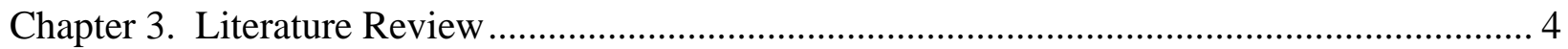

Characteristics of Red Spruce....................................................................................... 4

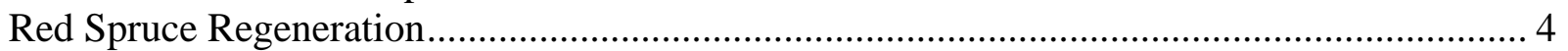

Seed Production and Dispersal ..................................................................................... 4

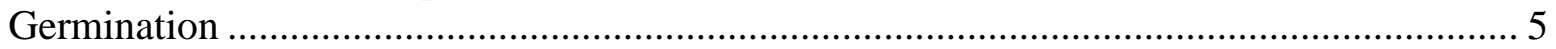

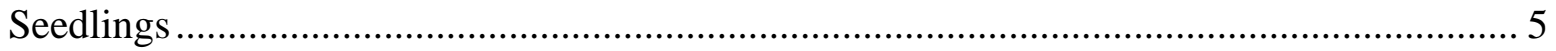

Distribution of the Red Spruce-fir Forest ........................................................................... 6

Quaternary History of the Spruce Forests.............................................................................. 8

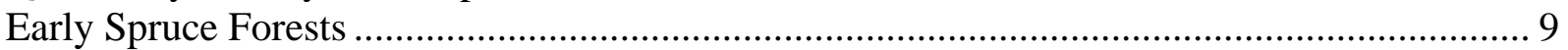

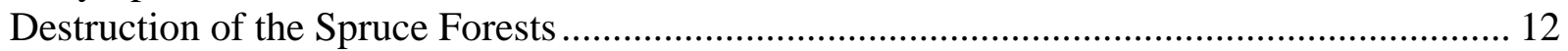

Present Condition of Red Spruce in the Central Appalachians ................................................. 13

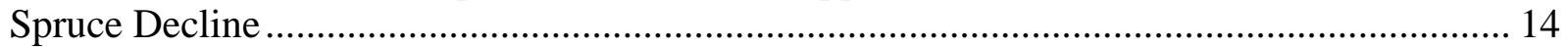

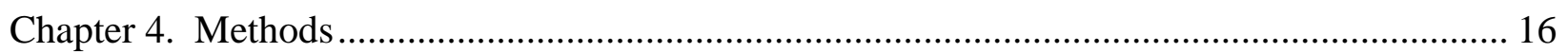

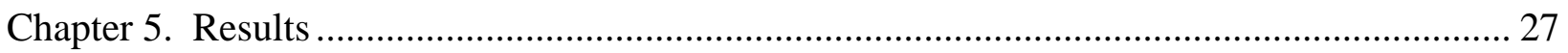

Current Site Conditions................................................................................................... 27

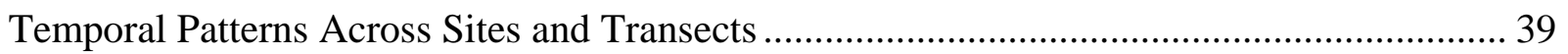

Trends by Forest Zone. ....................................................................................................... 52

Present condition of forest zones ......................................................................................... 52

Temporal Patterns: Red Spruce Zone ……………………............................................ 57

Temporal Patterns: Ecotone Zone........................................................................................ 61

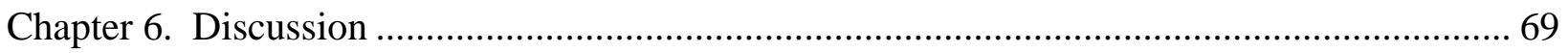

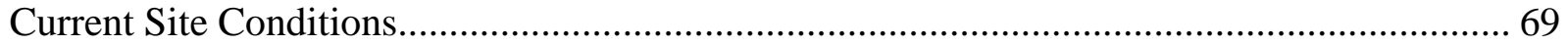

Temporal Patterns in Red Spruce Across Sites and Transects .................................................. 74

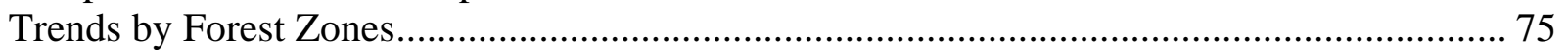

Temporal Patterns by Forest Zone........................................................................................... 75

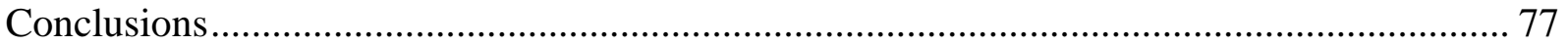

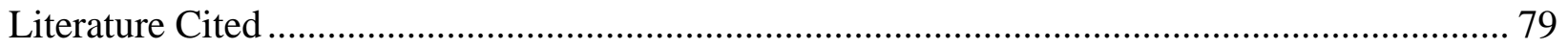




\section{List of Tables}

Table 1. Overview of Red Spruce Study Sites originally established by Adams and...........................................16

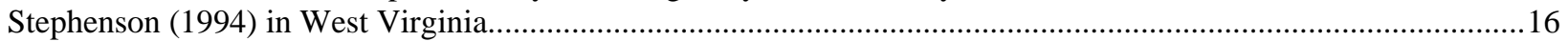

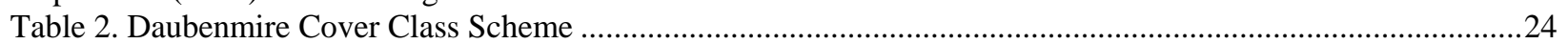

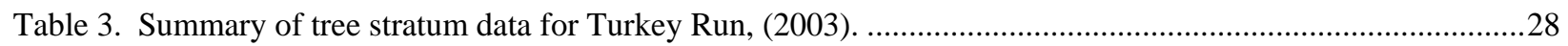

Table 4. Summary of Tree Stratum Data for McGowan Mountain, 2004 .......................................................30

Table 5. Summary of Tree Stratum Data for Cranberry, 2004......................................................................33

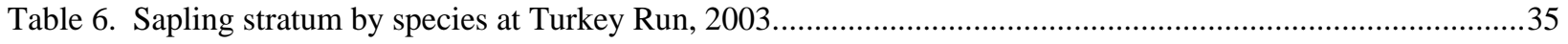

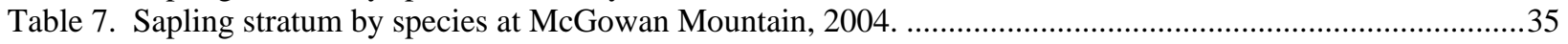

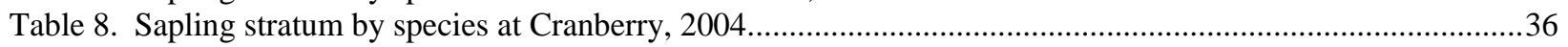

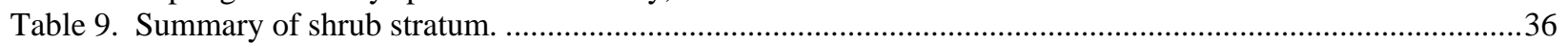

Table 10. 2003, 2004 Seedling densities, stems per hectare; (importance values) by site.....................................37

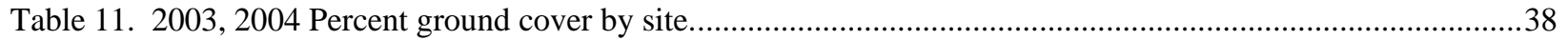

Table 12a. Red spruce tree stratum variable means for the ANOVA by forest zone. Means with different letters indicate statistical significance..........................................................................................................53

Table 12b. Hardwood species tree stratum variable means for the ANOVA by forest zone. Means with different

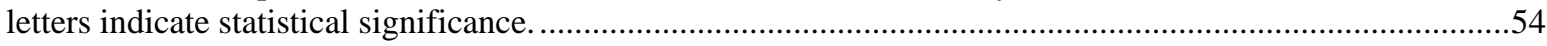

Table 13. Sapling variables for ANOVA by forest zone (all sites combined) showing mean values. Means with different letters indicate statistical significance..

Table 14. Seedling variable means (all size classes combined) for the ANOVA by forest zone. Means with different

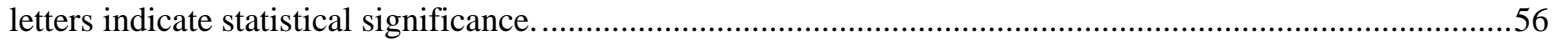

Table 15a. Red spruce tree stratum variable means for the ANOVA for the red spruce zone, first survey to last survey. Means with different letters indicate statistical significance. .....................................................57

Table 15b. Hardwood species tree stratum variable means for the ANOVA for the red spruce zone, first survey to last survey. Means with different letters indicate statistical significance................................................58

Table 16. Sapling variable means for the ANOVA for the red spruce zone, first survey to last survey. Means with different letters indicate statistical significance. .................................................................................59

Table 17. Seedling variable means (size classes pooled) for the ANOVA for the red spruce zone, first survey to last survey. Means with different letters indicate statistical significance. .......................................................60

Table 18a. Red spruce tree stratum variable means for the ANOVA for the ecotone zone, first survey to last survey. Means with different letters indicate statistical significance............................................................61

Table 18b. Hardwood species tree stratum variable means for the ANOVA for the ecotone zone, first survey to last survey. Means with different letters indicate statistical significance. .....................................................62

Table 19. Sapling variable means for the ANOVA for the ecotone zone, first survey to last survey. Means with

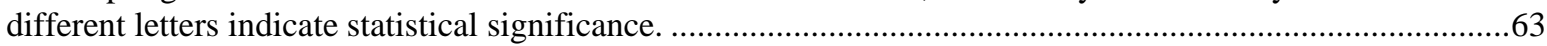

Table 20. Seedling variable means (size classes pooled) for the ANOVA for the ecotone zone, first survey to last survey. Means with different letters indicate statistical significance. .......................................................63

Temporal Patterns: Hardwood Zone.

Table 21a. Red spruce tree stratum variable means for the ANOVA for the hardwood zone, first survey to last survey. Means with different letters indicate statistical significance.

Table 21b. Hardwood tree stratum variable means for the ANOVA for the hardwood zone, first survey to last survey. Means with different letters indicate statistical significance.

Table 22. Sapling variable means for the ANOVA for the hardwood zone, first survey to last survey. Means with different letters indicate statistical significance.

Table 23. Seedling variable means (size classes pooled) for the ANOVA for the hardwood zone, first survey to last survey. Means with different letters indicate statistical significance. .................................................67

Table 24. Site summaries for all species and for red spruce from the $2003-2004$ samples.................................70

Table 25. Presence (1) - Absence $(0)$ of tree species at the three sites..........................................................71 


\section{List of Figures}

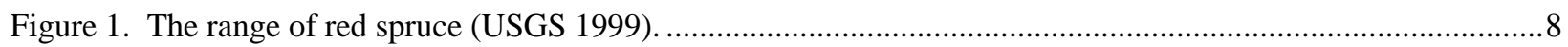

Figure 2. Location of the Turkey Run study area in Tucker County, West Virginia..............................................18

Figure 3. Location of the McGowan Mountain study area in Randolph County, West Virginia. .............................20

Figure 4. Location of the Cranberry study area in Pocahontas County, West Virginia........................................22

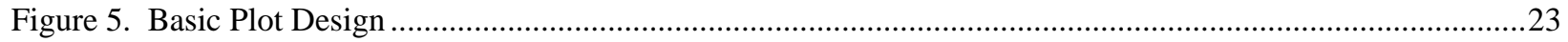

Figure 6. Diameter distribution graph for all species and dbh classes at Turkey Run 2003.................................29

Figure 7. The percent contribution by species to the small diameter classes ( $\leq 8 \mathrm{~cm}$ class) left, ...........................29

and the large diameter classes (> 8 cm class); right, Turkey Run 2003..........................................................29

Figure 8. Diameter distribution graph for all species and dbh classes at McGowan Mountain 2003.......................31

Figure 9. The percent contribution by species to the small diameter classes ( $\leq 8 \mathrm{~cm}$ class) left, and the large diameter

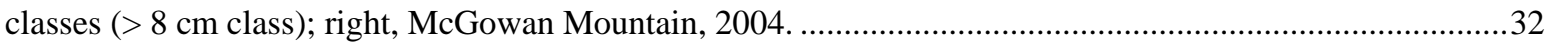

Figure 10. Diameter distribution graph for all species and dbh classes at Cranberry 2004....................................34

Figure 11 . The percent contribution by species to the small diameter classes ( $\leq 8 \mathrm{~cm}$ class) left, and the large

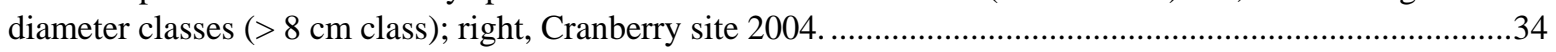

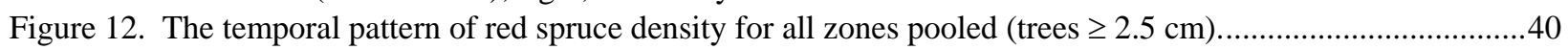

Figure 13. The temporal pattern of hardwood density for all zones pooled (trees $\geq 2.5 \mathrm{~cm})$..............................40

Figure 14. The temporal pattern of red spruce relative density for all zones pooled (trees $\geq 2.5 \mathrm{~cm}) \ldots \ldots \ldots \ldots \ldots \ldots \ldots . . .12$

Figure 15. The temporal pattern of hardwoods relative density for all zones pooled (trees $\geq 2.5 \mathrm{~cm}$ )..................42

Figure 16. The temporal pattern of red spruce relative basal area for all zones pooled (trees $\geq 2.5 \mathrm{~cm}$ ). ...............43

Figure 17. The temporal pattern of hardwoods relative basal area for all zones pooled (trees $\geq 2.5 \mathrm{~cm}$ ). ..............43

Figure 18. The temporal pattern of red spruce importance values for all zones pooled (trees $\geq 2.5 \mathrm{~cm}$ ) ................44

Figure 19. The temporal pattern of hardwood importance values for all zones pooled (trees $\geq 2.5 \mathrm{~cm}$ )................44

Figure 20. The temporal pattern of red spruce sapling densities for all zones pooled..........................................46

Figure 21. The temporal pattern of hardwood sapling densities for all zones pooled. ........................................46

Figure 22. The temporal pattern of importance values for red spruce saplings for all zones pooled......................48

Figure 23. The temporal pattern of importance values of hardwood saplings for all zones pooled. ........................48

Figure 24. The temporal pattern of red spruce seedling densities for all size classes and forest zones combined.....50

Figure 25. The temporal pattern of hardwood seedling densities for all size classes and forest zones combined......50

Figure 26. The temporal pattern of importance values for red spruce seedlings for all size classes and forest zones combined.

Figure 27. The temporal pattern of importance values for hardwood seedlings for all size classes and forest zones combined.

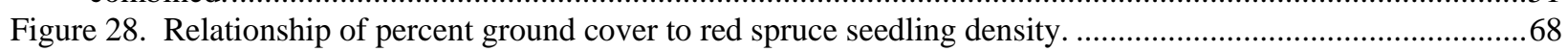

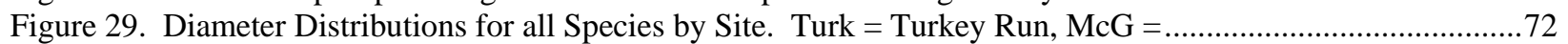

McGowan Mountain; Cran = Cranberry Site. ..................................................................................

Figure 30. The change in the relative density of red spruce over time by forest zone. Bars with different letters indicate the change was statistically significant. 


\section{Chapter 1. Introduction}

Red spruce (Picea rubens) is the most characteristic tree composing the Appalachian red spruce or spruce-fir forest type. The red spruce-fir forest type is a unique and fragile ecosystem of eastern North America. In the central Appalachians these spruce forests are remnants from the last glaciation, which created climatic conditions currently associated with more northerly latitudes. Present-day stands represent the result of extended climate change, regional natural disturbances, and intense anthropogenic influences. Despite the limited distribution and extent of the red spruce-fir forest type it exerts considerable ecological and economical impact. The spruce forest type, particularly in the central and southern Appalachians, provides habitat to various rare and endangered flora and fauna. The shallow root systems of red spruce stabilize the soils in turn protecting watersheds. Red spruce is valued for timber and paper products. The red spruce-fir forest type is also noted for its aesthetic value, which ultimately supports tourism.

Red spruce is distributed from the maritime provinces of Canada, extending south along the highest elevations of the Appalachian Mountains. Red spruce is commonly associated with a fir (Abies spp.) component throughout its natural range, which accounts for the name "spruce-fir forest type”. Balsam fir (Abies balsamea) is associated with red spruce across its northern range, while Fraser fir (Abies fraseri) serves as a co-dominant with red spruce in its southern extension. The fir component is generally absent in central Appalachian red spruce stands with the exception of a few isolated stands in wetlands.

The spruce-fir forests of northern and southern North America have frequently been a focal point for recent and past research. The spruce forests of the central Appalachians have received relatively less attention. Nevertheless, studies across the northeast have raised considerable concern about the overall health and future of the spruce-fir forest type of eastern North America. Studies have documented an apparent health decline and a subsequent vigor reduction in red spruce in high elevation stands. In some areas, high rates of red spruce mortality have been observed. Dendroecological studies have documented significantly reduced rates of radial growth in red spruce. The balsam woolly adelgid (Adelges piceae) has practically eliminated the adult Frasier fir populations of the southern Appalachians. The effects of this infestation on the dynamics of the southern spruce-fir forest are presently only speculative. The red spruce-fir forests have been described as experiencing a general "forest decline" in relation to 
the combination of these factors. Several hypotheses have been proposed to explain this forest decline phenomenon. Pollution, biotic stresses, climate change, and natural stand dynamics have all been offered as explanations however, no general consensus has been reached. These concerns have prompted many questions about the management and future of the spruce-fir forest type.

The spruce forests of the Central Appalachians are less extensive, often limited to small mountaintop stands as a result of being replaced by hardwoods after the extensive logging and subsequent fires of the late 1800's and early 1900's. The regeneration present at a site provides an important indication regarding the future composition of a forest stand. Obviously, if a species is unable to produce viable seed and seedlings, it is unlikely that it will be present in the future stand. The majority of past studies have focused on the red spruce of the overstory stratum. The decline of red spruce has raised concern about its possible replacement by aggressive hardwood species from the forests surrounding the spruce forest type. This could be especially true if climatic warming is driving this decline. Studies are necessary to determine whether red spruce stands are advancing, retreating, or remaining static in the face of these problems. The assessment of red spruce regeneration is an essential element for determining whether the red spruce forest type can persist in the face of an apparent decline. 


\section{Chapter 2. Objectives}

The primary goal of this study was to re-examine red spruce regeneration across three Central Appalachian sites in West Virginia approximately 10 - 11 years after the sites were originally examined by Adams and Stephenson (1994). The sites were examined on temporal and spatial scales to draw inference as to whether the spruce forest type is expanding, remaining static, or retreating. The following objectives were addressed to explore this question.

- To quantify and describe the composition, structure and ecological characteristics at three sites in terms of overstory trees, saplings, seedlings, shrubs, and ground cover.

$\mathrm{H}_{\mathrm{o}}=$ The composition, structure, and ecological characteristics of the three sites are not significantly different.

- To examine the changes in the tree stratum by site and forest zone (hardwood, ecotone, spruce) and test for significant changes.

$\mathrm{H}_{\mathrm{o}}=$ Changes in the tree stratum by site and forest zone are not significantly different.

a To examine changes of spruce and hardwood regeneration (seedlings \& saplings) by site and forest zone and test for statistically significant changes.

$\mathrm{H}_{\mathrm{o}}=$ Changes in regeneration densities of spruce and hardwood species by site and forest zone are not significantly different.

- To investigate if ground cover affects the success of seedlings densities.

$\mathrm{H}_{\mathrm{o}}=$ Ground cover does not significantly affect red spruce seedling success. 


\section{Chapter 3. Literature Review}

\section{Characteristics of Red Spruce}

Red spruce (Picea rubens) is a medium-sized shade-tolerant evergreen tree that is best suited to cool moist conditions. It produces a shallow root system that spreads laterally protecting soils from erosion. Throughout its range red spruce is commonly associated with acidic soils such as Spodosols, Inceptisols and, less frequently, Histosols. Red spruce grows in a pH range between 4 and 5.8 (USDA, NRCS. 2004). The growth rate of red spruce is best characterized as medium. Mature trees may achieve an average diameter of 30 to $61 \mathrm{~cm}$. Red spruce grows to a height of 18 to $23 \mathrm{~m}$ in the north, and can reach a height of $35 \mathrm{~m}$ in the

southern Appalachians (Burns and Honkala, 1990). The bark of red spruce is thin therefore trees are subject to severe damage from fire. The needles and sap produced by red spruce are also flammable. This species can realize a lifespan of up to 400 years.

\section{$\underline{\text { Red Spruce Regeneration }}$}

\section{Seed Production and Dispersal}

Red spruce can begin to produce seed as young as 15 years of age (Frank and Bjorkbom, 1973) however, good seed production does not usually occur until the tree is at least 30 years old (USDA, NRCS. 2004). The actual age an individual tree produces seed is determined by various site conditions. Once an individual reaches the canopy, the crown can receive direct sunlight and thicken, setting the stage for quality seed production. In dense, even-aged stands robust seed crops may not occur until the trees are up to 50 years old (Korstian, 1937). Vigorous trees produce good seed crops at a frequency of 3 to 8 years.

The seeds of red spruce are small (139,000 / lb), lightweight, and winged making them well adapted for wind dispersal. Red spruce seeds fall $1.2 \mathrm{~m}$ per second in still air (Burns and Honkala, 1990). The effective range of seed dispersal is 61 meters (Frank and Bjorkbom, 1973). Hughes and Bechtel (1997) investigated spruce seedfall into a clearcut. The greatest concentration of spruce seeds was found at 25-30 meters from the forest edge. After 30 meters 
the number of spruce seeds was reduced but remained fairly constant to the forest edge. Red spruce cones mature in the early fall and seeds drop throughout the late fall and winter.

\section{Germination}

Seeds on the forest floor may retain their viability for approximately one year, therefore no seedbank strategy is employed. Red spruce seeds typically germinate during the spring following their dispersal, although some seeds may germinate in the fall shortly after they are released. It is unlikely that fall germinals will survive the winter. During a good seed year, 60 to 80 percent of the seeds are viable, however in poor years seed viability is markedly decreased (Korstian, 1937). Greenwood and McConville (2002) found red spruce germination rates ranging from $33 \%$ - 83\% across two temperature regimes with no water stress. Their study revealed that red spruce germination rates were best under $20^{\circ} \mathrm{C}$ days and $10^{\circ} \mathrm{C}$ nights.

Germination is epigeal and can occur on almost any medium. The single most important factor in influencing the germination of red spruce seedlings is an adequate moisture supply (Burns and Honkala, 1990). Mineral soil maintains adequate moisture levels while sustaining moderate temperatures making it a superb medium for red spruce germination. Litter and humus are less suitable because they are hotter and more susceptible to desiccation (Frank and Bjorkbom, 1973). The presence of bryophytes on the forest floor indicates adequate moisture is available to support red spruce regeneration. Baldwin (1933) found red spruce regeneration to be more abundant on north and east facing exposures. He believed this corresponded to greater protection from the direct rays of the sun and wind.

\section{Seedlings}

Ultimately, the success of red spruce regeneration is dependent more on the survival of seedlings than on their requirements for germination (Frank and Bjorkbom, 1973). The substrate upon which red spruce germinates will affect the success of its establishment. Red spruce that germinates on leaf litter is unlikely to become established. The small fibrous roots of red spruce are often not capable of penetrating the litter layer. In addition, these individuals are likely to succumb to water stress once the litter layer dries. Seedlings that germinate on a bed of moss are more likely to be successful. The moss provides an adequate supply of moisture for the 
developing seedling. In addition, bryophyte mats may provide red spruce seedlings with a source of nutrients such as P, N, Fe, K, Ca and Mg (Dibble et al., 1999).

Red spruce seedlings may be considered established once they obtain a height of $15.2 \mathrm{~cm}$ (Frank and Bjorkbom, 1973). Seedling establishment is best under the cover of a canopy in light intensities as low as $10 \%$ of full sunlight. However, after a red spruce seedling becomes established it obtains optimal growth under light conditions of $50 \%$ or of full sunlight. Red spruce can persist in the understory stratum for an extended period of time and maintain the ability to respond favorably to release. Red spruce has reportedly responded favorably to release even after 145 years of suppression (Burns and Honkala, 1990).

\section{Distribution of the Red Spruce-fir Forest}

The red spruce-fir forest type occurs from the maritime provinces of Canada and extends southward along the highest peaks of the Appalachian Mountains. The Appalachian spruce-fir forest type is primarily composed of two dominant tree species, red spruce (Picea rubens) and a fir (Abies) component. Balsam fir (Abies balsamea) constitutes the fir component in the northern expression of this forest type. Fraser fir (Abies fraseri) occupies this role in southern communities. The Appalachian spruce-fir forest type can be subdivided based on the occurrence of the fir constituent. This broad grouping results in three geographic areas (Figure 1), the northern, central, and southern Appalachian spruce-fir forest zones.

The northern Appalachian spruce-fir forest type occurs north of Pennsylvania and extends into Canada, encompassing approximately $42^{\circ}-47^{\circ} \mathrm{N}$ latitude (Figure 1). The northern Appalachian spruce-fir forest is composed of two dominant trees, red spruce (Picea rubens) and Balsam fir (Abies balsamea). The southern Appalachian spruce-fir area covers $35^{\circ}-37^{\circ} \mathrm{N}$ latitude and is expressed on the highest peaks of extreme southern Virginia, Tennessee and North Carolina. Fraser fir (Abies fraseri) occurs in the southern spruce-fir communities. The southern spruce-fir community reaches it northernmost limit in southwestern Virginia on Mt. Rogers (Stephenson and Adams, 1984; Rheinhardt and Ware, 1984).

The central Appalachian spruce forest type ranges from $37^{\circ}-42^{\circ} \mathrm{N}$ latitude, and is mainly concentrated on the highest peaks of Virginia and West Virginia. The central Appalachian spruce type is dominated by red spruce (Picea rubens). In West Virginia red spruce 
is generally confined to elevations above $1066 \mathrm{~m}$ (3500 ft) (Hicks and Mudrick 1994), but can occur as low as $955 \mathrm{~m}$ as evidenced by populations at Canaan Valley. The fir constituent is generally absent from mid-Appalachian stands with the exception of a few isolated communities of Balsam fir (Abies balsamea), restricted to wet swampy areas. Balsam fir has been recorded from four locations in West Virginia at, Canaan Valley (Tucker Co.), Blister Run (Randolph Co.), Blister Swamp (Pocahontas Co.), and the Stony River Dam (Grant Co.) (Strausbaugh and Core 1977, Stephenson and Adams 1986). Certain morphological characteristics associated with the bracts and cone scales of balsam fir occurring at Blister Run and other central Appalachian sites are intermediate between the balsam fir of the north and the Fraser fir of the south (Strausbaugh and Core 1977). Fulling (1936) considered the balsam fir occurring in the central Appalachians a separate species, Abies intermedia. He proposed that Abies intermedia represented a transitional species between the northern and southern firs.

Comparative studies have concluded that the northern and southern representatives of the red spruce-fir forest type are structurally similar (Oosting and Billings, 1951; McIntosh and Hurley, 1964; Stephenson and Adams, 1984). However, differences do exist. The spruce forests of the north experience a cooler climate and are found at lower elevations in relation to the central and southern expressions. The spruce-fir forests of the mid-Appalachians contain the fir component in a lower proportion in relation to northern and southern spruce-fir communities (Stephenson and Clovis, 1983). Generally, the fir component is absent from central Appalachian stands. 


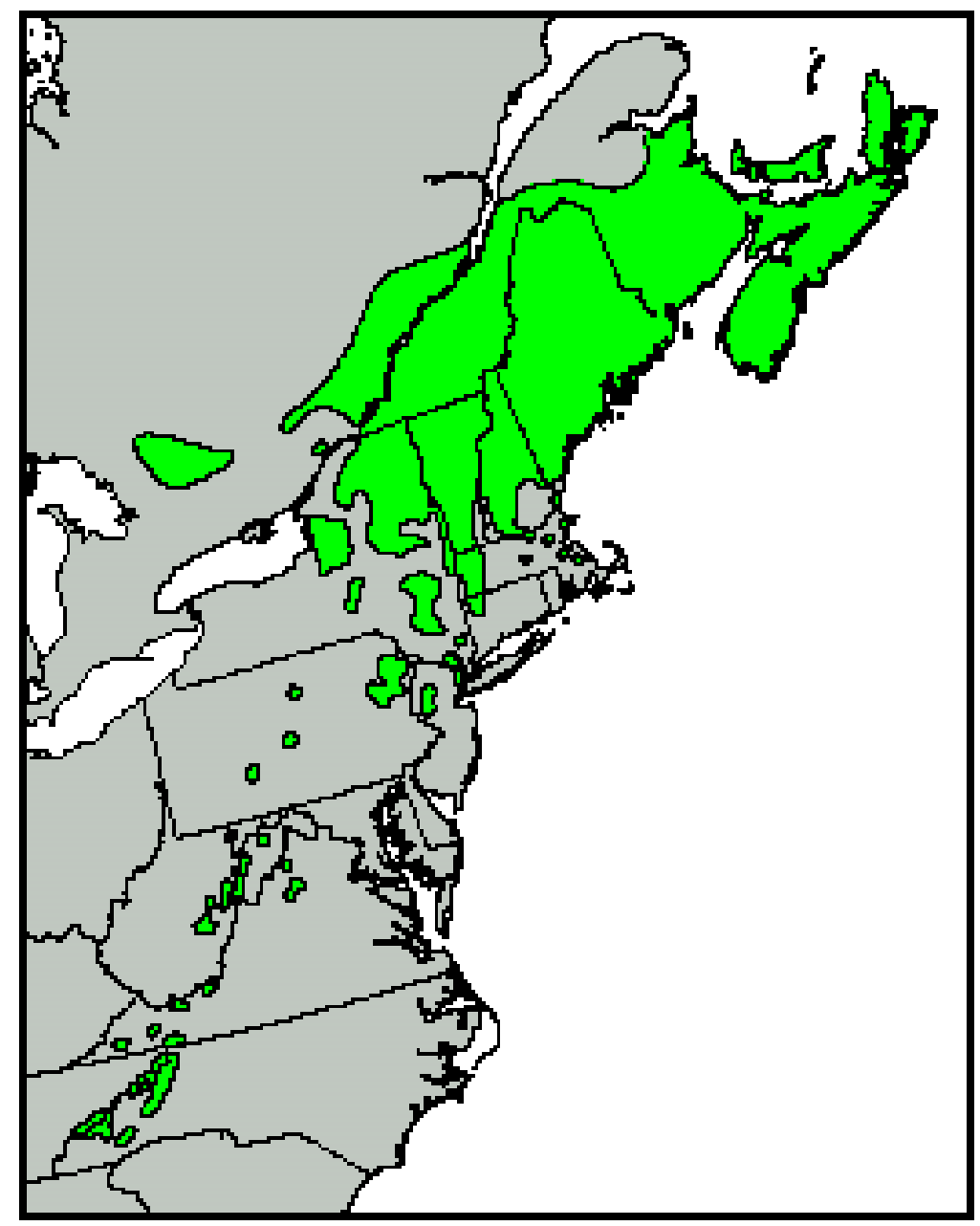

Figure 1. The range of red spruce (USGS 1999).

\section{Quaternary History of the Spruce Forests}

The climate 18,000 years ago and subsequently the flora of eastern North America were quite different than today. Glaciers covered northern North America and had reached their southern most extent at $41^{\circ}$. The glaciers strongly influenced the climate of eastern North America. The ocean level was reduced as a consequence of the water stored on land in the glaciers. The surface temperature of the ocean was considerably less than at present. The combination of these factors resulted in a primarily cold, dry, and windy climate (Watts, 1979). During this time spruce was prevalent across broad area south of the ice sheet and hardwood species were present much further south to present day Georgia and beyond. The central 
Appalachians were dominated by tundra conditions at this time. When the ice sheet began to retreat the spruce populations generally flowed the ice sheet. During the period of 12000 to 8000 years ago spruce populations experienced a general decline in extent. The present day distribution of spruce was in place approximately 6000 years ago when the ice sheet was almost completely gone (Jacobson et al. 1987).

Watts (1979) examined pollen cores from Cranberry Glades in West Virginia. His data suggested 18000 years ago the area was a treeless tundra zone dominated by sedges. A forest dominated by Picea, Pinus, and Abies was evidenced in the pollen record 12000 years ago. Shortly after this Tsuga appeared and increased dramatically after establishment. Tsuga's arrival was accompanied by Ostrya, Tillia, Juglans, Quercus, and Fagus. Tsuga dominated the period from 10000 to 6000 years before present, which correlates with the warmest period of the Holocene. During this warm period Picea pollen dropped and almost disappeared from the pollen record, suggesting that the warm climate drove it away from the immediate vicinity of the bog and to higher elevations. Following the end of this warm period Tsuga experienced a sharp decline from 4800 to 4600 years before present. The near loss of Tsuga from the area was attributed to disease rather than the climate change. The Tsuga decline resulted in an increase of

Picea, as well as Betula, and Acer saccharum. The removal of Tsuga from the canopy must have allowed Picea to expand its range from the mountains as well as releasing Betula and Acer, which are all common constituents of present day stands in the general area.

\section{Early Spruce Forests}

Little is known about the spruce forests that existed when the first Europeans arrived in North America. Forest inventories or scientific studies documenting the structure and composition of these forests are lacking. Most of our knowledge comes from the travelogues and articles of early explorers, which are based largely on personal observations without any strict sampling regime. Early logging records and personal accounts from lumbermen who worked in these forests serve to provide additional insight to these early forests. However, care must be taken when interpreting these early accounts. Allard and Leonard (1952) consulted loggers who worked in these early spruce forests in their attempt to reconstruct the conditions of 
these early stands. They pointed out that the information provided by these loggers was mainly about the "practical aspects of logs and lumber" without much insight concerning the ecology or specific flora of these forests. Clarkson (1964) noted that various aspects of early articles and travelogues were “amusingly exaggerated”. In addition, Bailey and Ware (1990) point out that in early logging operations hemlock (Tsuga spp.) was often recorded as spruce and as a result early logging records citing spruce do not necessarily indicate Picea.

However, early sources leave little doubt the virgin spruce forests were quite impressive. Large, towering trees formed a thick dense canopy allowing little light to penetrate producing a dark forest interior. Cool, moist air often supported a misty fog. Giant trees that had succumbed to old age or windthrow littered the ground. A plush cover of bryophytes carpeted the rocky forest floor and fallen trees. Immense Rhododendron thickets rendered some areas virtually impassable. The characteristics of these forests evoked lore of ill-fated adventures into them.

The red spruce of these virgin forests were large magnificent trees reaching heights up to 120 feet and attaining diameters of four feet. The largest of the spruce boasted diameters six feet or greater and could yield five 16-foot logs (Clarkson, 1964). Red spruce reportedly formed extensive, essentially pure, stands at the highest elevations. In the lower elevations of its range, red spruce dominated the canopy interspersed by various hardwoods. Trees associated with these early forests included, balsam fir (Abies balsamea), eastern hemlock (Tsuga canadensis), yellow birch (Betula alleghaniensis), sugar maple (Acer saccharum), white ash (Fraxinus americana), basswood (Tilia americana), wild cherry (Prunus serotina), and beech (Fagus grandifolia) (Allard and Leonard, 1952).

Little information exists, concerning the assemblages of trees that composed the understory stratum of the early spruce forests. Low light conditions associated with mature undisturbed spruce forests suggest a non-diverse, species depauperate understory stratum. Allard and Leonard (1952) noted that the following species were common on the logged and burned over spruce lands and may have been a minor constituent of the pre-disturbance understory. The list includes, pin cherry (Prunus pensylvanica), choke cherry (Prunus virginiana), quaking aspen (Populus tremuloides), large-toothed aspen (Populus grandidentata), striped maple (Acer pensylvanicum) and mountain maple (Acer spicatum). The silvical characteristics, particularly shade intolerance, and seed characteristics of theses species makes it likely that they were important in forest gaps following disturbances such as windthrow. Their position in the forest 
was likely temporary until spruce was able to fill the gaps. Shade tolerant species occurring in the overstory, such as red spruce, balsam fir (on wet swampy soils), sugar maple, yellow birch, and American beech (Fagus grandifolia) were probably more prevalent in the sparse understory of a mature undisturbed spruce stand.

The shrub stratum of the early spruce forest was likely sparse and low in diversity, although more diverse shrub assemblages were likely associated with disturbed areas. Great rhododendron (Rhododendron maximum) was undoubtedly a common constituent of the shrub stratum in the early spruce forests, and apparently formed vast, virtually impenetrable thickets, which could cover a considerable area. One of these thickets was said to average eight to ten feet in height or more (Allard and Leonard, 1952). These great rhododendron "hells” inspired stories of hunters that went in too far, becoming entangled or lost, never to return.

Not surprisingly, little information is available describing the flora in the forest floor of pre-settlement red spruce forests. The forest floor stratum was likely simple, consisting of various bryophytes, lycopodia, and a few flowering plants that could withstand the dense shade. A thick wet mat of various bryophytes, particularly Sphagnum, and liverworts such as Bazzania was likely a consistent feature of the forest floor. Loggers who worked in these early forests noted a deep humus layer mixed with forest debris while Sphagnum and other mosses formed a constant ground cover (Allard and Leonard, 1952). References cited by Clarkson (1964) support this moss covering as well as the occurrence of Lycopodium. In addition, it was noted that flowering plants were not common with the exception of mountain wood sorrel (Oxalis montana) and Trillium spp. Accounts compiled from Allard and Leonard (1952) cite the occurrence of plants common to more northern latitudes including, small cranberry (Vaccinium oxycoccos), creeping snowberry (Gaultheria hispidula), hairy New York aster (Symphyotrichum novi-belgii), nerveless woodland sedge (Carex leptonervia), panicled bulrush (Scirpus microcarpus) black girdle bulrush, (Scirpus atrocinctus), yellow marsh marigold (Caltha palustris), and Jack in the pulpit (Arisaema triphyllum). They also noted several species of perennial woody vines including grape vine (Vitus sp.), Virginia creeper (Parthenocissus quinquefolia), poison ivy (Rhus radicans), and greenbriers (Smilax sp.). 


\section{Destruction of the Spruce Forests}

Estimates of West Virginia's spruce forests of the 1700's range from 200,000 to 600,000 hectares, whereas present day estimates indicate between 17,500 to 44,500 hectares remain (Mayfield, 1997). The most recent report (Griffith and Widmann 2003) estimates 9,600 hectares of the red spruce forest type remain in West Virginia in 2000. Clearly the extent of spruce forests in the mid-Appalachians has been considerably reduced over the past two centuries. Logging and subsequent fires decimated the bulk of the original spruce forests of the mid-Appalachians. The practice of hacking was popular in spruce stands prior to the Civil War. Farmers bought large tracts of spruce lands, girdled the trees, and then set fire to clear the brush and fallen timber in order to make pasture land. A period of large-scale logging began in 1870 and ended during the late 1920's. During this period more than 30 billion board feet of lumber was removed from the mountains of West Virginia. Red spruce was recognized as the most valuable tree in the Allegheny Mountain section of West Virginia (Clarkson, 1964). It was prized for both pulpwood and lumber, which led to its exploitation. As a result red spruce stands were often cut very heavily or clearcut leaving considerable slash behind. The slash dried and served as a fuel source. The fires typically killed any residual trees and these dead trees served as fuel for additional fires that followed (Korstian, 1937). The fires often destroyed any regeneration present and burned the organic humus layer down to the mineral soil. Frequent rains associated with these areas quickly eroded any remaining soil leaving nothing but exposed rock. Sites subjected to this degree of degradation have been observed to remain treeless and unproductive 60 or more years later (Eagar and Adams, 1992). The fires of this logging era were often unintentional. They were often the result of an escaped campfire or sparks from the wood and coal burning engines of the trains, skidders and loaders that were used to log the forest (Clarkson, 1964).

Hardwood species frequently came back in areas that had been cut and burned over. Initially, a site would become occupied by dense thicket of blackberry and raspberry briers. Pin cherry and yellow birch would quickly rise up and dominate the site. Korstian (1937) found that 
pin cherry would typically persist for 15 to 20 years, at which time it would give way to yellow birch and other hardwood species. The northern hardwood covertype now occupies many areas that were once occupied by the red spruce forest type. Griffith and Widmann (2003) reported that the northern hardwoods forest type occupied 968,700 hectares in West Virginia.

\section{Present Condition of Red Spruce in the Central Appalachians}

Present-day central Appalachian red spruce populations exist as relatively small communities restricted to the highest mountain peaks. In some instances red spruce forms almost pure stands that cap the mountaintops. In general, red spruce exists in conjunction with a various admixture of hardwood species. It is estimated that as of 2000 the spruce forest type covered approximately 9,600 hectares in West Virginia. The national forest contains $69 \%$ of the red spruce forest type and the remaining $31 \%$ is privately owned. Seventy-five percent of this area is classified as fully stocked, while $21 \%$ is poorly stocked and the remaining $4 \%$ is overstocked (Griffith and Widmann 2003). The red spruce forest type contains the greatest growing stock volume per acre of any forest covertype in West Virginia. The red spruce growing stock is estimated at $2042.3 \mathrm{ft}^{3} / \mathrm{ac}$, while the next most productive forest type is the northern hardwoods at $1722.5 \mathrm{ft}^{3}$ /ac (Hicks and Mudrick 1994).

Pauley (1989) surveyed second growth spruce stands in West Virginia. He reported red spruce basal area (stems $>2.5 \mathrm{~cm}$ ) at $33.4 \mathrm{~m}^{2} /$ ha with a density of 1215 stems per hectare. Yellow birch, red maple, mountain ash (Pyrus americana), black cherry, mountain holly (Ilex montana), American birch and eastern hemlock were also recorded in the tree stratum. The basal area for all species pooled was $38.8 \mathrm{~m}^{2} /$ ha with a density of 1755 stems per hectare. Pauley's results collaborated with a preceeding survey of second growth spruce stands in West Virginia (Stephenson and Clovis 1983) which also found yellow birch and red maple to be common associates in the red spruce forest type. Basal area and densities of red spruce were not reported in that study, however the total density of stems $>2.5 \mathrm{~cm}$ for all species was reported to be 1580 stems per hectare, which is similar to that found by Pauley. Adams and Stephenson (1989) surveyed old growth spruce forests at four locations in the central Appalachians. They reported basal areas for all species (stems $>2.5 \mathrm{~cm}$ ) ranging from 35.3 to $46.2 \mathrm{~m}^{2} /$ ha and densities of 855 
to 1410 stems per hectare. They recorded sapling densities ranging from 515 to 4660 stems per hectare, while seedling densities ranged from 0 to 53000 stems per hectare.

The stand dynamics of red spruce forests of the eastern United States are dominated by a wind throw disturbance regime. The windthrow of older trees and individual tree mortality are the main occurrences creating mainly small forest gaps (Eagar and Adams, 1992). These openings release advanced regeneration persisting on the forest floor. The extreme shade tolerance and long lifespan of red spruce allows it to persist in the understory for a considerable period of time as a result it may eventually reach the canopy in response to a disturbance event (Fajvan and Seymour, 1993). Wu et al. (1999) found that $72 \%$ of the canopy red spruce stems underwent an average of 1.43 (up to a maximum of 7) suppression episodes before reaching the canopy. These suppressions events lasted 19.05 years on average.

\section{Spruce Decline}

The red spruce-fir forests have been described as experiencing a "forest decline”. Studies have documented declining health and vigor in red spruce, which prompted concern about the health and future of the spruce-fir forest type. Studies reported relatively high rates of mortality among red spruce particularly in the north. Siccama et al (1982) reported approximately a 50\% decrease in red spruce density and basal area over 15 years. Scott et al (1984) reported a reduction of red spruce basal area by $60 \%$ to $70 \%$ from the early 1960 's to 1982 . Mielke et al (1986) reported that 33\% of West Virginia’s red spruce volume was in dead or declining trees. Silver et al (1991) reported a significant increase in the number of dead red spruce trees from $26.1 \%$ to $36.7 \%$ over a five-year period. Tritton and Siccama (1990) surveyed several forest types occurring in the eastern United States and found the spruce forest type contained the highest percentage of dead trees ranging from $11 \%$ to $43 \%$ dead stems. These trends for red spruce were not evident in southern populations however the balsam woolly adelgid has devastated adult fir populations of the south (Smith and Nicholas, 1998).

Further research documented unexplainable reduced radial growth trends in red spruce. Red spruce basal area in New England stands followed an increasing trend until around 1960, then they experienced declining trend to of 13\% to 40\% below it peak by 1980 (Hornbeck and Smith 1985). In addition, Adams et al (1985) found that spruce trees in the central Appalachians 
were experiencing a growth-trend decline, which initiated in the late 1960's and had not recovered by the time of their survey. A more recent survey (Schuler et al. 2002) of West Virginia red spruce reveled this growth decline phenomenon from 1930 to 1990. However, since that time period the growth rates have stabilized. This reduced growth-trend phenomenon has also been observed in southern red spruce stands, however the degree of decrease was less and began about 5 to 10 years later.

Various hypotheses have been proposed to account for this forest decline phenomenon. Pollution, biotic stresses, climate change, and natural stand dynamics have all been offered as explanations however, no general consensus has been reached. McLaughlin et al. (1987) proposed climate change as a driving factor. Johnson et al. (1988) proposed that climate variations in particular drought coincided with this and historic red spruce declines. Hamburg and Cogbill (1988) further proposed that a trend of increasing mean annual and mean annual summer temperatures were driving this spruce decline event. Other studies suggest that pollution in the form of acid rain and subsequent heavy metal deposition, aluminum toxicity, and calcium depletion play important roles (McLaughlin et al. 1990, Geballe et al. 1990). Roth and Fahey (1998) found that acid precipitation altered the composition of the ectomycorrhizal community. The effects of this are not certain at this time. Further studies have found that some variable may be predisposing red spruce to winter injury and serves as an impetus to weaken spruce. Some evidence suggests that elevated ozone and radiation heating may lead to greater winter damage (Hadley and Amundson 1992, Waite et al 1994). Additional research suggests that the stress encountered by red spruce crowns exposed to strong winds reduces radial growth and may play a role in this spruce decline phenomenon (Harrington 1986, LeBlanc 1990, LeBlanc and Raynal 1990). The exact cause of spruce decline is not understood, however it is likely a complex interplay between these and various other factors. 


\section{Chapter 4. Methods}

Three locations in West Virginia were included in this study. These are referred to as the McGowan Mountain site located in Randolph county, the Turkey Run site in Tucker county, and the Cranberry site in Pocahontas county (Table. 1). The sites are situated in the central Appalachian mountains of West Virginia. Adams and Stephenson (1994) originally established these study areas to assess and monitor the ecotone between the hardwood and spruce forest types.

Table 1. Overview of Red Spruce Study Sites originally established by Adams and Stephenson (1994) in West Virginia.

\begin{tabular}{|c|c|c|c|c|c|c|c|}
\hline Site & Elev (m) & Aspect & Slope (\%) & \# Plots & Date Established & Years Sampled & Oldest RS \\
\hline Turkey Run & 1,134 & $10^{\circ}(\mathrm{N})$ & 5 & 10 & 1992 & $92,93,94,95,03$ & 193 \\
\hline McGowan & 1,158 & $90^{\circ}(\mathrm{E})$ & $<5$ & 7 & 1993 & $93,94,95,97,00,04$ & 67 \\
\hline Cranberry & 1,341 & $20^{\circ}(\mathrm{N})$ & 25 & 7 & 1994 & $94,95,96,04$ & 204 \\
\hline
\end{tabular}

The Turkey Run transect was established by Adams and Stephenson (1994) in 1992 in Tucker County, West Virginia. The site sets atop McGowan Mountain in the Fernow Experimental Forest. The Fernow Experimental Forest is part of the Monogahela National Forest system and is bordered by the Otter Creek Wilderness Area (Figure 2). This transect is set along a northern aspect ( $10^{\circ}$ azimuth) and attains an elevation of 1,134 meters. The transect exhibits a slight $5 \%$ slope and is thus fairly flat.

Turkey Run is part of the Pottsville Geological formation of the Allegheny Mountain section of the Appalachian Plateau. Exposed geological substrata are mostly Paleozoic rocks composed of sand stone layers and coal-bearing strata. (Adams and Stephenson 1989). The soils are generally sandy loams and clay loams (Korsitan 1937). These soils are shallow and highly acidic as a result of the geology, organic matter degradation, and acidic deposition in the area (Missel 1999). Climate and weather data does not exist for this specific site. Limited data collected by Darlington (1943) from Cranberry Glades in Pocahontas County provides an idea of 
basic conditions. Mean annual precipitation is $130 \mathrm{~cm}$, while the average annual temperature is $5.5^{\circ} \mathrm{C}$. Hicks and Mudrick (1994) reported that elevations supporting spruce populations receive $178 \mathrm{~cm}$ per year and realize a mean January temperature of $-2.2^{\circ} \mathrm{C}$

Information detailing the long-term history of this stand is lacking. The Elk Lick Lumber Company and the Otter Creek Boom and Lumber company operated in the general area between 1897 and 1916 (Clarkson, 1964). It is likely that a large portion of the general area was subject to timber operations and possibly subsequent fires that were common during this time. The oldest tree in the study area was determined to be 193 years of age using annual ring count. This suggests that if the stand had been logged it may have only been subjected to a partial harvest. Some of the trees show signs of past fire damage. The remnants of Hurricane Hugo in 1989 resulted in a major windthrow event at Turkey Run. The majority of the large red spruce as well as other species were toppled creating large canopy gaps. This has provided an excellent opportunity to study whether the spruce or hardwoods are regenerating in the gap. 


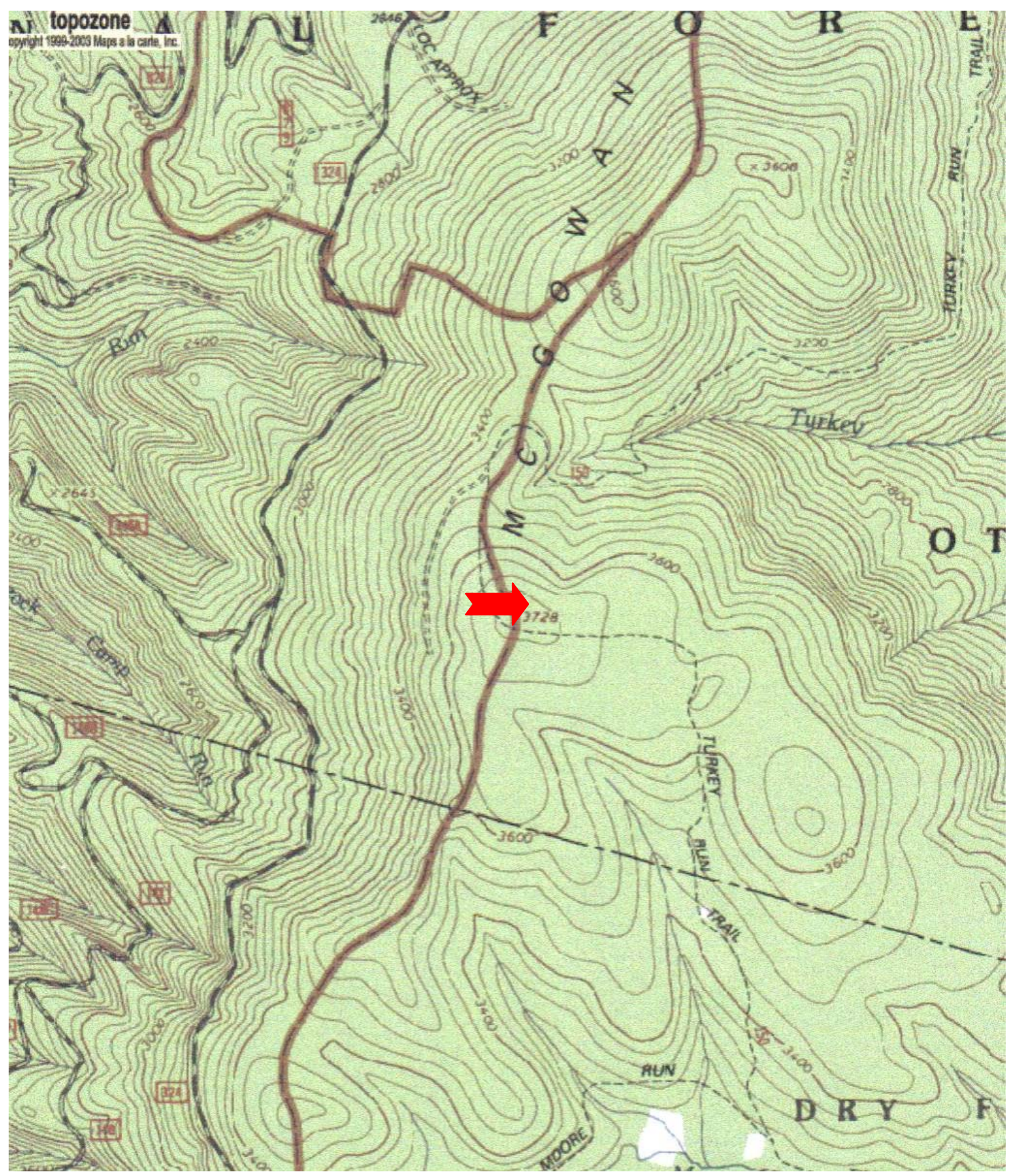

Figure 2. Location of the Turkey Run study area in Tucker County, West Virginia.

The McGowan Mountain transect was established by Adams and Stephenson (1994) in 1993 in Randolph County, West Virginia (Figure 3). McGowan Mountain is in the Fernow Experimental Forest, a part of the Monogahela National Forest system, and is bordered by the Otter Creek Wilderness Area. The site has an eastern aspect of $90^{\circ}$. The McGowan Mountain 
transect is perched at an elevation of 1,158 meters. The transect is relatively level with a slope less than $5 \%$. The soils, geologic strata, and climate data are the same as described for Turkey Run.

Similarly there exists no detailed information concerning the long-term history of this specific stand, although as noted above, the Elk Lick Lumber Company and the Otter Creek Boom and Lumber company were also active in this area between 1897 and 1916. The average age of this stand is the youngest of the three study areas. The oldest tree in this stand is 67 years old. This fact certainly suggests that this stand was produced by a major disturbance such as logging and possibly the fires that commonly follow logging operations of this time. Missel (1999) proposed that the area was logged and hardwoods such as pin cherry and red maple established in the area for a period of approximately 28 years until the spruce was able to reestablish and form the present day stand. 


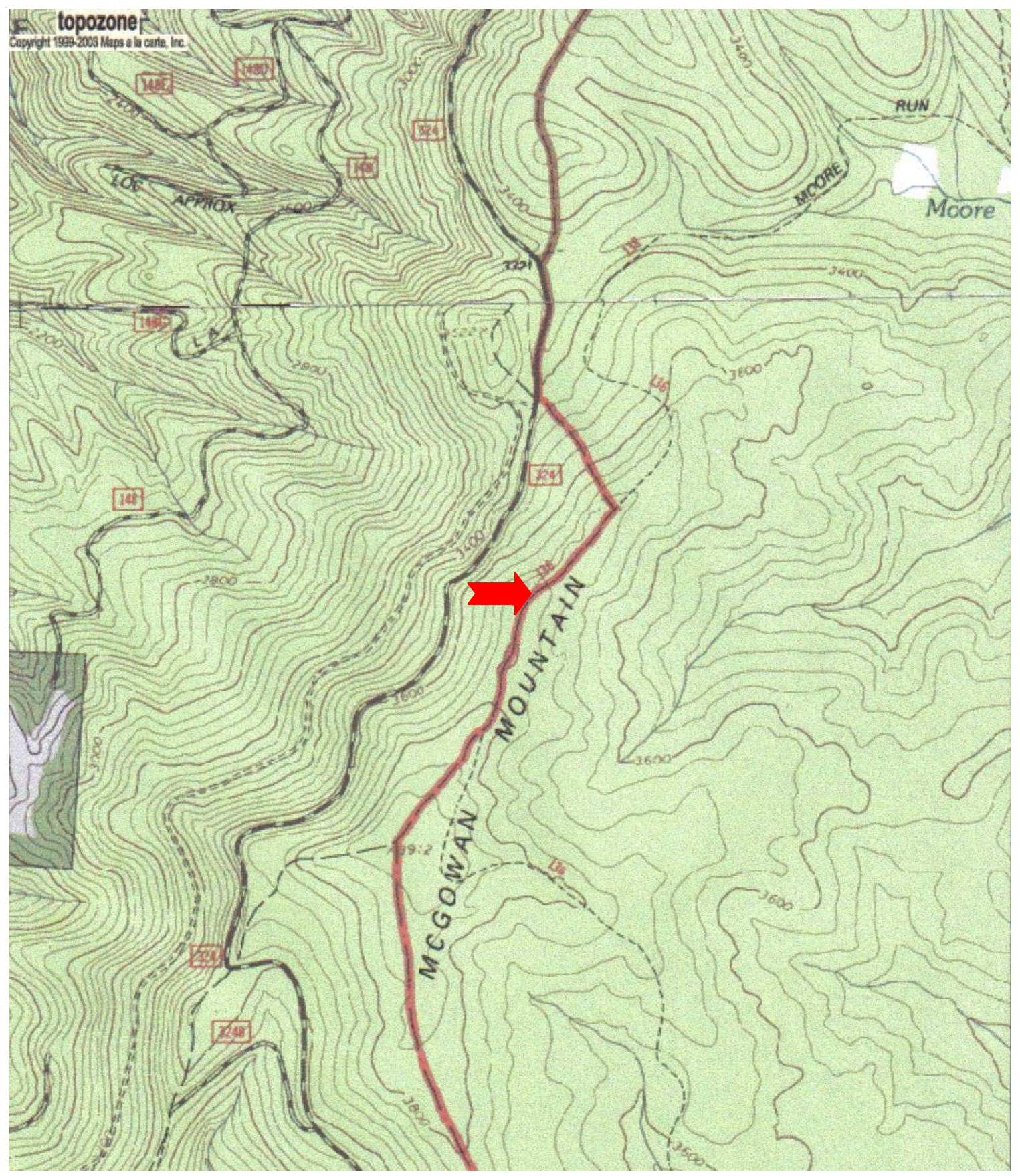

Figure 3. Location of the McGowan Mountain study area in Randolph County, West Virginia. 
The Cranberry site was established by Adams and Stephenson (1994) in 1994. The site is located along the Scenic Highway, US Route 150, in the Cranberry Wilderness (Figure 4). The Cranberry transect has a north aspect with a $20^{\circ}$ azimuth. This transect is located at the highest elevation of the three study sites at 1,341 meters and the transect runs on a moderate slope of $25 \%$. This is the steepest of the three sites. The soils, geologic strata, and climate data are the same as described for Turkey Run.

As with the other two, no direct information exists detailing the long-term history of the stand. The Cranberry Wilderness area was logged extensively during the turn of the century. The spruce of the area were generally cut heavily or clearcut. Large portions of the general area burned over quite extensively. This is evidenced by areas near the site that at present have failed to be reclaimed by forest and are composed of barren rock and sparsely scattered trees. The stand sampled appears to have escaped the fate of these surrounding areas. The site is composed of sizable spruce trees, the oldest determined to be 204 years of age. 


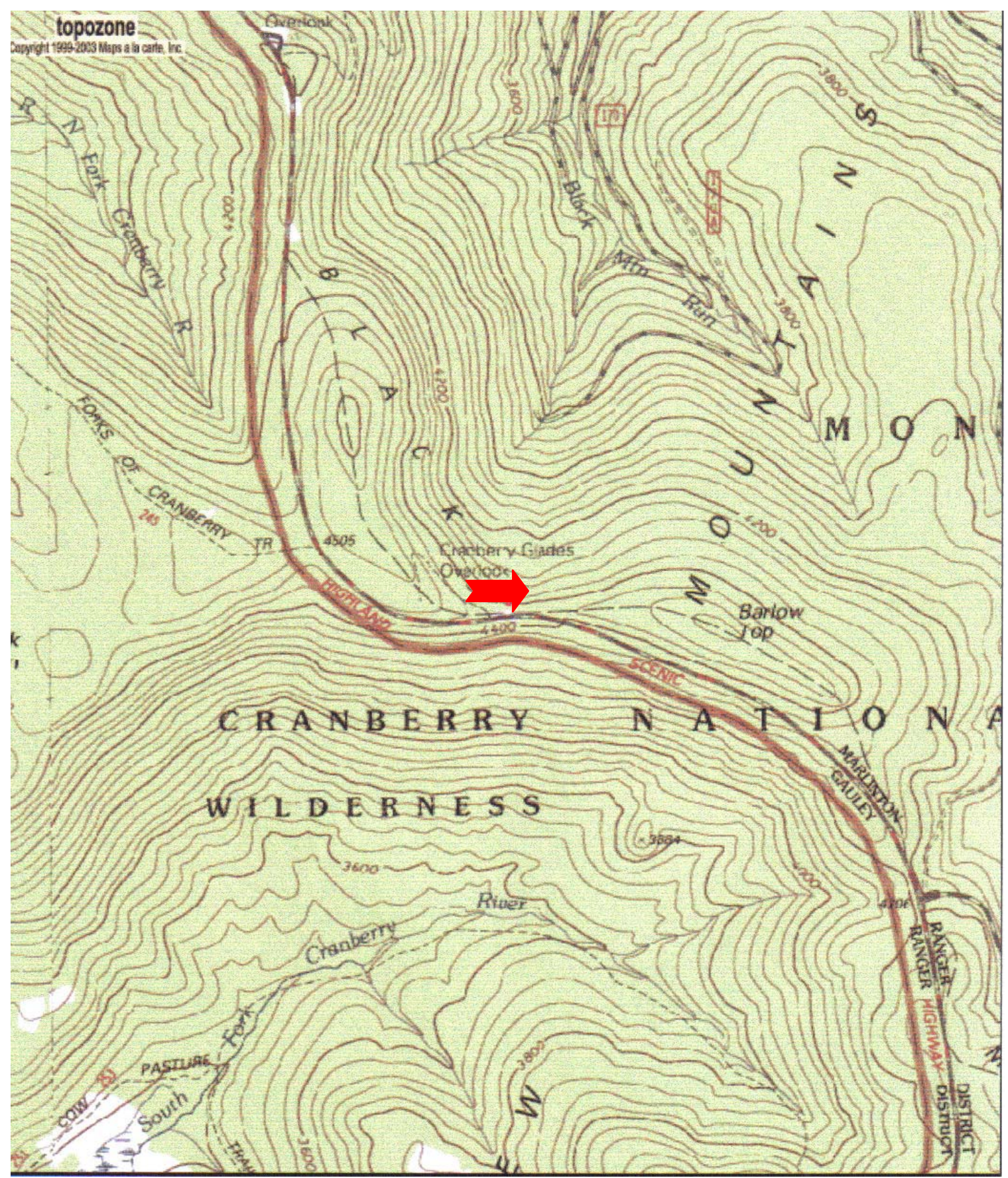

Figure 4. Location of the Cranberry study area in Pocahontas County, West Virginia.

This study utilized transects previously established transects by Adams and Stephenson (1994). Permanent belt transects were established so that the plots extend through the hardwoodspruce ecotone represented at each site. A transect consisted of a series of contiguous quadrats. 
The quadrats are $10 \times 10 \mathrm{~m}$ squares, thus delimiting an area of $100 \mathrm{~m}^{2}$. The corners of the individual quadrats were marked with permanently driven steel stakes (Figure 5).

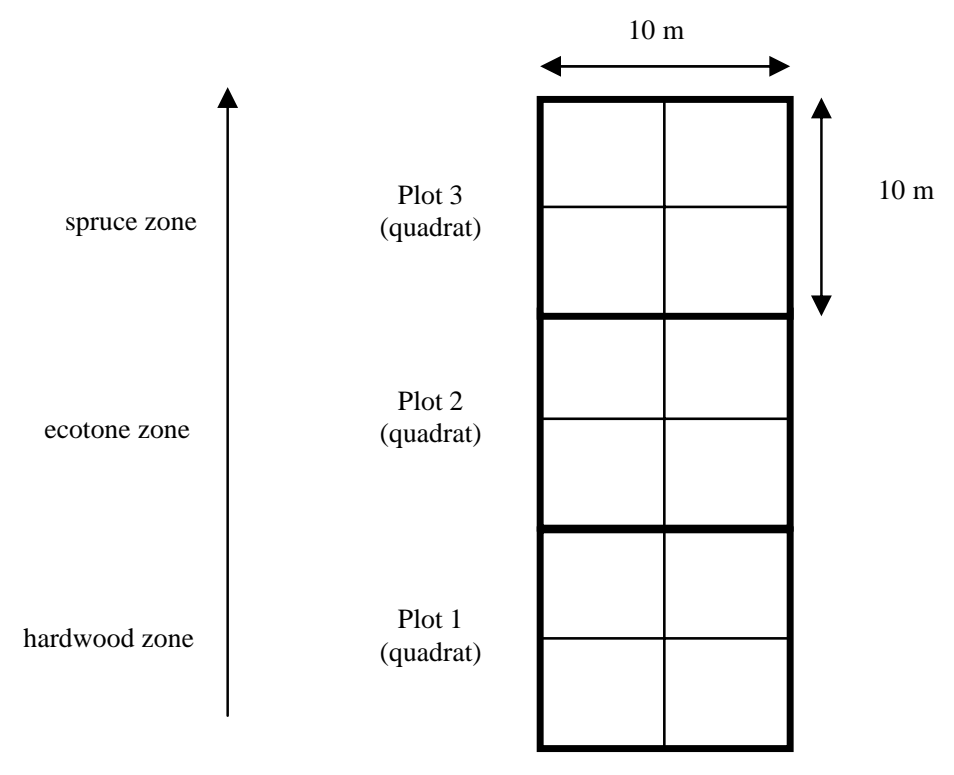

Figure 5. Basic Plot Design

The general aspect of each transect was determined with a compass. The slope of each transect was attained by a clinometer sighting. When the plots were originally installed trees with a diameter at breast height (DBH) greater than or equal to $2.54 \mathrm{~cm}$ had been marked with permanent metal tags at their base. The position of these trees were mapped and their diameters were measured at DBH. Trees were determined to species and measured at DBH. Dead trees were also recorded. Each quadrat was divided into four 5x5 m subplots and sapling densities were recorded in each subplot. Saplings were designated as stems with a diameter measuring less than $2.54 \mathrm{~cm}$, which had attained a height greater than or equal to $1.0 \mathrm{~m}$ tall. Saplings were identified to species and recorded in their respective plots. Stem densities of shrubs were determined fore each species and recorded in one randomly predetermined 5x5 m subplot within each quadrat. Seedlings were determined to species and classified into four classes, (1.) 
germinal (recently germinated), (2.) $<10 \mathrm{~cm}$, (3.) $10 \mathrm{~cm}$ to $0.25 \mathrm{~m}$ tall, and (4.) $0.25 \mathrm{~m}$ to $1 \mathrm{~m}$ tall. Seedling densities were counted in two $1 \mathrm{~m} \times 1 \mathrm{~m}$ (a total area of $2.0 \mathrm{~m}^{2}$ ) predetermined randomly selected subplots from each quadrat. Ground cover was determined in the same two randomly predetermined $1 \mathrm{x} 1$ meter subplots used to count seedling densities. Ground cover of herbaceous plants, bryophytes, coarse woody debris, rocks and bare ground (exposed soil) were determined according to the Daubenmire cover class value system (Table. 2).

Table 2. Daubenmire Cover Class Scheme

\begin{tabular}{cc}
\hline Cover Class Estimated \% Cover \\
\hline 1 & Trace-5\% \\
2 & $5-25 \%$ \\
3 & $25-50 \%$ \\
4 & $50-75 \%$ \\
5 & $75-95 \%$ \\
6 & $95-100 \%$ \\
\hline
\end{tabular}

The tree and seedling data were examined on a plot-by-plot basis and pooled by site. This provided an overall description of each site, which allowed each location to be compared and contrasted with the others. This analysis permitted a comparison of the overall trends for red spruce at each site. The data from each site were also grouped and analyzed by cover type classification (i.e. hardwoods, ecotone, spruce). This provided the basis to examine the spatial dynamics occurring at each site. Comparing results of the original inventories with the current data allowed me to determine whether red spruce was expanding its range, remaining static, or retreating. Finally, the data from all sites were pooled. The GENMOD procedure in the SAS software system was used to fit generalized linear models to the pooled data to search for correlations between red spruce regeneration and various site variables from the overstory, and understory strata.

Since the study sites had been previously sampled at several intervals by Adams and Stephenson (1994), the data collected from each year permitted me to examine the temporal dynamics occurring at each site. The change at each study area was evaluated over an approximate ten-year span. The Turkey Run site was analyzed from 1992 to 2003, an eleven- 
year span. The McGowan Mountain transect was be assessed over eleven years from 1993 to 2004 and the Cranberry site was examined from 1994 to 2004, a ten year span.

Basic per plot calculations of basal area $\left(\mathrm{m}^{2}\right.$ and $\left.\mathrm{m}^{2} / \mathrm{ha}\right)$, as well as trees per hectare were performed. Diameter distributions by species using four-centimeter classes were constructed to show the structure of the tree stratum. The relative density (RD) by species was calculated as follows:

$$
R D=\left(\frac{\# \text { stems spp. } A / h a}{\text { tot } \# \text { stems } / \text { ha }}\right) * 100
$$

The relative basal area (RBA) by species was calculated by the following equation:

$$
R B A=\left(\frac{B A / \text { ha spp.A }}{\text { tot BA/Ha }}\right) * 100
$$

Species level importance value indices were constructed by the following equation:

$$
I V=\frac{R D+R B A}{2}
$$

The Shannon-Wiener Diversity Index (H') was calculated by the following equation.

$$
H^{\prime}=-\sum_{i=1}^{s}\left(p_{i} \ln p_{i}\right)
$$

$\mathrm{Pi}$ is the portion of importance of the ith species, in this case $p i=\frac{I V}{100}$.

In addition, Pielou's eveness index will be computed as follows.

$$
E=\frac{H^{\prime}}{\ln (S)}
$$

$\mathrm{H}^{\prime}$ is the Shannon-Wiener diversity index. $\mathrm{S}$ is species richness, simply the number of different species present.

The data for the saplings were simply multiplied by the appropriate expansion factor and stems/ha were calculated by species and totaled for each year the site was surveyed. The seedling data were calculated in terms of stems/ha by species, and size class, then totaled for each year. Similarly, the shrub strata densities (stems/ha) were tabulated by species and totaled for each year. Relative density was used as a measure of importance for saplings, seedlings, and shrubs (see below). ANOVA was used to test for any statistically significant changes over time or across sites. 


$$
I V=\left(\frac{\text { Stems } / \text { ha Spp.A }}{\text { tot } \# \text { Stems } / \text { ha }}\right) * 100
$$

The ground cover estimate was determined by the Daubenmire cover class value method. Each cover category was assigned a ranking from 1 to 6 . The cover class values were then converted to the midpoint value from each class (Table 3). The arithmetic mean is then calculated across each cover category providing the percent cover estimate for that category.

The variables of interest were calculated for each plot and these means were used for the analysis. Site, forest zone, and year were used as class variables. The proc GLM function in the SAS software system was used to perform the analysis of variance (ANOVA). This procedure uses the least squares to fit general linear models. The Duncan's new multiple range test (LSD function) was used when significant differences were present to determine which treatments were statistically significant. The interactions of site, forest zone, year, site * year, site * forest zone, and site * forest zone * year were investigated. The proc GENMOD function of the SAS software system was used to look for correlations between the percent ground cover and the density of red spruce seedlings (all size classes combined). This procedure fits generalized linear models that allow the mean of the population to depend on a linear predictor by the use of a nonlinear link function. The Poisson distribution was used for this prediction procedure. The mean density of seedlings for each site and each year were analyzed against the percent cover means for each site and year. 


\section{Chapter 5. Results}

\section{$\underline{\text { Current Site Conditions }}$}

The following site descriptions summarize the most recent inventory (2003 - 2004) of the complete transect at each site. The plot designations of hardwood, ecotone, and red spruce zones are ignored. This provides a general snapshot of the complete transitional area from hardwood dominance to spruce dominance present at each site. Summarizing the data in this manner provides an opportunity to assess the overall temporal patterns occurring at each site. A more detailed analysis of the forest cover types at each site will be examined in subsequent sections.

Ten species were present in the tree stratum at Turkey Run (Table 3). Based on the transect data it was estimated that 2470 trees/ha were present in the stand yielding a basal area of $42.99 \mathrm{~m}^{2} /$ ha. Calculated importance values revealed that red spruce (Picea rubens) (32.9), American beech (Fagus grandifolia) (20.8), yellow birch (Betula lenta) (14.2), and red maple (Acer rubrum) (11.7) were the most important species composing the tree stratum. These were all the species with importance values equal to or greater than ten, and they accounted for $75.0 \%$ of the total basal area and $84.2 \%$ of the stems tallied for the site. Red spruce was present at the highest density, accounting for 53.0\% of the total stems (1310 stems/ha). Yellow birch contributed the greatest basal area $\left(9.81 \mathrm{~m}^{2} / \mathrm{ha}\right)$ accounting for $22.8 \%$ of the total basal area for the site.

Striped maple (Acer pennsylvanicum) (7.1), red oak (Quercus rubra) (4.8), black cherry (Prunus serotina) (4.6), and eastern hemlock (Tsuga canadensis) (3.1) were minor "less important" stand constituents at the Turkey Run site. Striped maple was the most abundant of this group with 270 stems/ha (10.9\% of the total stems). Red oak ( $8.3 \%$ of the total basal area) and black cherry (8.4\% of the total basal area) yielded the highest basal area of this group with $3.57 \mathrm{~m}^{2} /$ ha and $3.63 \mathrm{~m}^{2} /$ ha respectively. Serviceberry (Amelanchier arborea) and cucumber magnolia (Magnolia acuminata) were present, however they did not appear to represent an important constituent at the site. 
Table 3. Summary of tree stratum data for Turkey Run, (2003).

\begin{tabular}{lccccc}
\hline \multicolumn{1}{c}{ Species } & $\begin{array}{c}\text { Basal Area } \\
\text { m }^{2} \text { /ha }\end{array}$ & $\begin{array}{c}\text { Density } \\
\text { trees/ha }\end{array}$ & $\begin{array}{c}\text { Relative } \\
\text { Density }\end{array}$ & $\begin{array}{c}\text { Relative } \\
\text { Basal Area }\end{array}$ & IV \\
\hline red spruce & 5.51 & 1310 & 53.0 & 12.8 & 32.9 \\
American beech & 8.11 & 560 & 22.7 & 18.9 & 20.8 \\
yellow birch & 9.81 & 140 & 5.7 & 22.8 & 14.2 \\
red maple & 8.83 & 70 & 2.8 & 20.5 & 11.7 \\
striped maple & 1.43 & 270 & 10.9 & 3.3 & 7.1 \\
red oak & 3.57 & 30 & 1.2 & 8.3 & 4.8 \\
black cherry & 3.63 & 20 & 0.8 & 8.4 & 4.6 \\
e. hemlock & 1.78 & 50 & 2.0 & 4.1 & 3.1 \\
serviceberry & 0.24 & 10 & 0.4 & 0.6 & 0.5 \\
cuc. magnolia & 0.08 & 10 & 0.4 & 0.2 & 0.3 \\
\hline \multicolumn{1}{c}{ SUM } & 42.99 & 2470 & 100 & 100 & 100 \\
\hline
\end{tabular}

The diameter distribution graph prepared for all species and size classes revealed a reverse J-shaped distribution (Figure 6). Small trees ( $\leq 8 \mathrm{~cm}$ class) had a density of 1940 stems/ha. The small tree class composed $78.5 \%$ of the total stems at Turkey Run. Red spruce and American beech were the dominant small tree species. Red spruce (1220 trees/ha) was the most abundant of the small tree species. Red spruce accounted for $62.9 \%$ of the small stems (Figure 7). American beech (410 stems/ha) was the second most abundant small tree species. It accounted for an additional $21.1 \%$ of the small stems. Striped maple (230 trees/ha) composed a noteworthy $11.9 \%$ of the small stems present at the site. Yellow birch (40 trees/ha), eastern hemlock (20 trees/ha), red maple (10 trees/ha), and cucumber magnolia (10 trees/ha) were present as small stems however collectively they accounted for only $4.1 \%$ of the small stems. Black cherry, red oak, and serviceberry were present in the tree stratum, but absent as small stems.

Large trees (> $8 \mathrm{~cm}$ class) accounted for $21.5 \%$ of the total stems at Turkey Run. American beech (150 trees/ha) was the most abundant large tree comprising $28.3 \%$ of the large stems (Figure 7). Yellow birch (100 trees/ha) and red spruce (90 trees/ha) made up 18.9\% and $17.0 \%$ of the large stems respectively. Red maple (60 trees/ha) is responsible for an additional 11.3\% of the large stems at this site. These species (American beech, yellow birch, red spruce, and red maple) had the highest calculated importance values and also constituted $75.5 \%$ of the large stems. The remaining species individually made up less than $10 \%$ of the large stems. Striped maple (40 trees/ha) was the highest of these accounting for $7.5 \%$ of the large stems. 
Eastern hemlock, red oak, black cherry and serviceberry were collectively responsible for the remaining $17.1 \%$ of the large stems. Cucumber magnolia was present as a small tree but it was not present as a large tree.

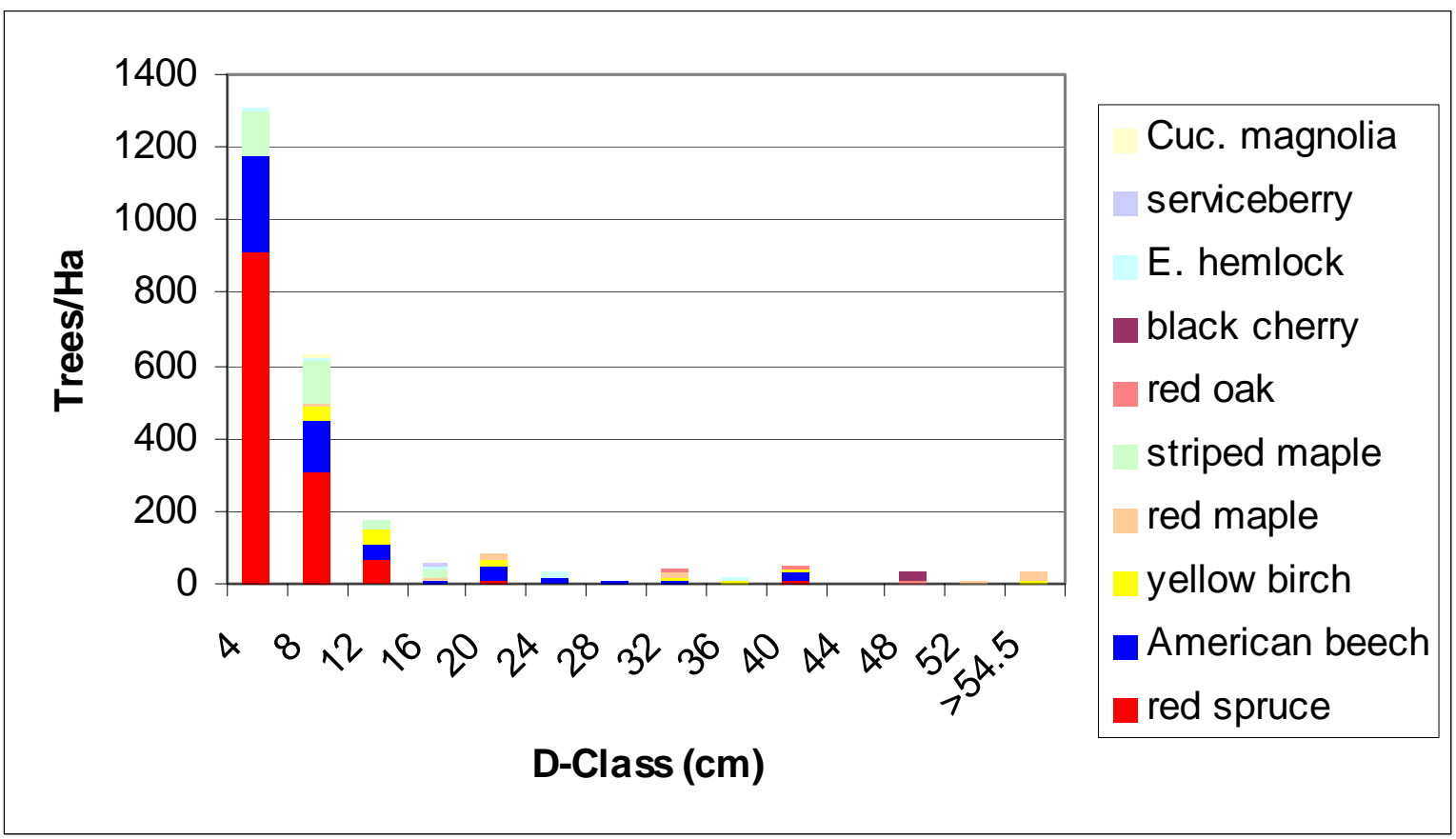

Figure 6. Diameter distribution graph for all species and dbh classes at Turkey Run 2003.
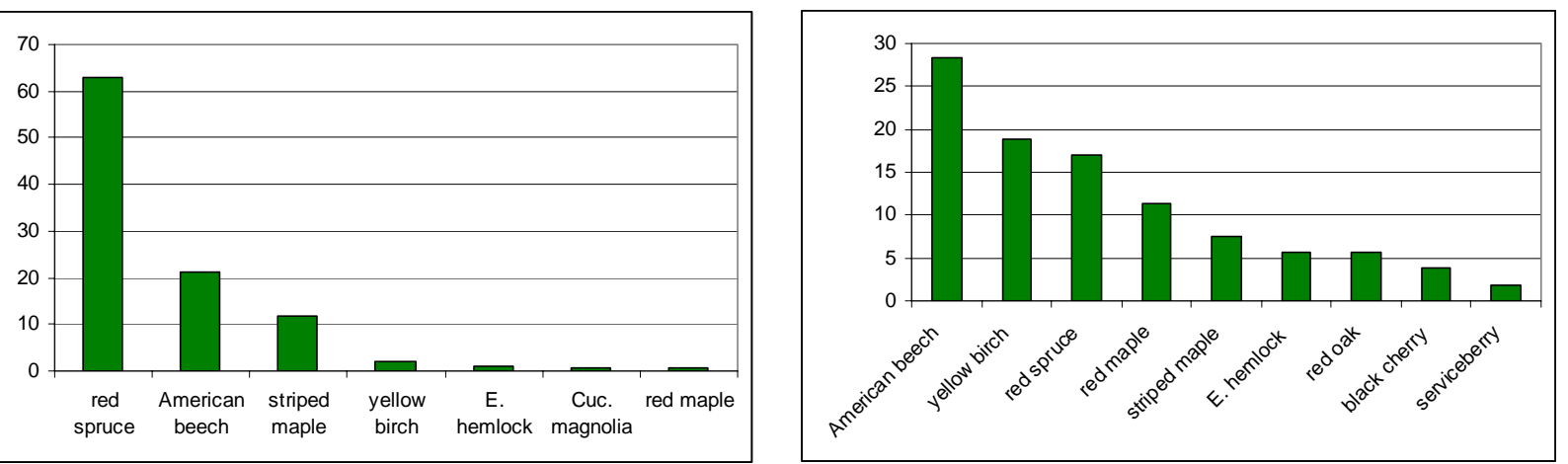

Figure 7. The percent contribution by species to the small diameter classes $(\leq 8 \mathrm{~cm}$ class) left, and the large diameter classes (> 8 cm class); right, Turkey Run 2003. 
The tree stratum at McGowan Mountain contained six species (Table 4). The stand density was estimated to be 2257 trees/ha with a basal area of $44.85 \mathrm{~m}^{2} /$ ha. Red spruce (50.9) and red maple (40.7) were clearly the dominant species based on calculated importance values. They were the only species that obtained importance values greater than or equal to ten. Combined, red spruce and red maple accounted for $94.6 \%$ of the basal area and $88.6 \%$ of the total stems tallied. Red spruce was the most abundant species accounting for $62.7 \%$ of the total stems (1414 stems/ha) at McGowan Mountain. Red maple accounted for 55.5\% of the total basal area (24.88 $\left.\mathrm{m}^{2} / \mathrm{ha}\right)$ at the site. Importance values for American beech (3.1), eastern hemlock (2.6), yellow birch (1.7) and mountain holly (i.e. mountain winterberry; Ilex montana) (1.1) indicated them to be minor constituents of the stand. Collectively these species only represented $5.4 \%$ of the basal area and $11.4 \%$ of the stem density.

Table 4. Summary of Tree Stratum Data for McGowan Mountain, 2004.

\begin{tabular}{lccccc}
\hline \multicolumn{1}{c}{ Species } & $\begin{array}{c}\text { Basal Area } \\
\mathbf{m}^{2} \text { /ha }\end{array}$ & $\begin{array}{c}\text { Density } \\
\text { trees/ha }\end{array}$ & $\begin{array}{c}\text { Relative } \\
\text { Density }\end{array}$ & \multicolumn{2}{c}{ Relative } \\
Basal Area & IV \\
\hline red spruce & 17.54 & 1414 & 62.7 & 39.1 & 50.9 \\
red maple & 24.88 & 586 & 25.9 & 55.5 & 40.7 \\
American beech & 1.06 & 86 & 3.8 & 2.4 & 3.1 \\
e. hemlock & 0.59 & 86 & 3.8 & 1.3 & 2.6 \\
yellow birch & 0.66 & 43 & 1.9 & 1.5 & 1.7 \\
mt. holly & 0.12 & 43 & 1.9 & 0.3 & 1.1 \\
\hline \multicolumn{1}{c}{ SUM } & 44.85 & 2257 & 100 & 100 & 100 \\
\hline
\end{tabular}

The diameter distribution for all species and size classes at the McGowan Mountain site revealed a reverse J-shaped curve (Figure 8). Small stems ( $\leq 8 \mathrm{~cm}$ class) accounted for $53.8 \%$ of the total stems. Red spruce (1000 trees/ha) overwhelmingly dominated the small tree class accounting for $82.4 \%$ of small stems (Figure 9). Eastern hemlock (71 trees/ha) was the next most abundant small stem, however it only accounted for $5.9 \%$ of the small stems. The remaining species (red maple, American beech, mountain holly, and yellow birch) accounted for only $11.7 \%$ of the small stems. Each of these species contributed less than $3.5 \%$ individually. All of the species that occurred in the tree stratum were represented in the small stem classes. 
Large trees (> $8 \mathrm{~cm}$ class) comprised $46.2 \%$ of the total stems present at McGowan Mountain. Red maple and red spruce dominated the large tree diameter classes (Figure 9). Red maple accounted for $52.1 \%$ of the large stems (543 trees/ha), while red spruce accounted for an additional 39.7\% (414 stems/ha). Combined these two species were responsible for $91.8 \%$ of the large stems at the site. American beech (43 trees/ha) accounted for an additional $4.1 \%$ of large stems. Yellow birch and eastern hemlock were responsible for the remaining $4.1 \%$ of trees in the large diameter classes. Mountain holly, typically a shrub species, was the only species represented in the small diameter classes that was not present as a large stem.

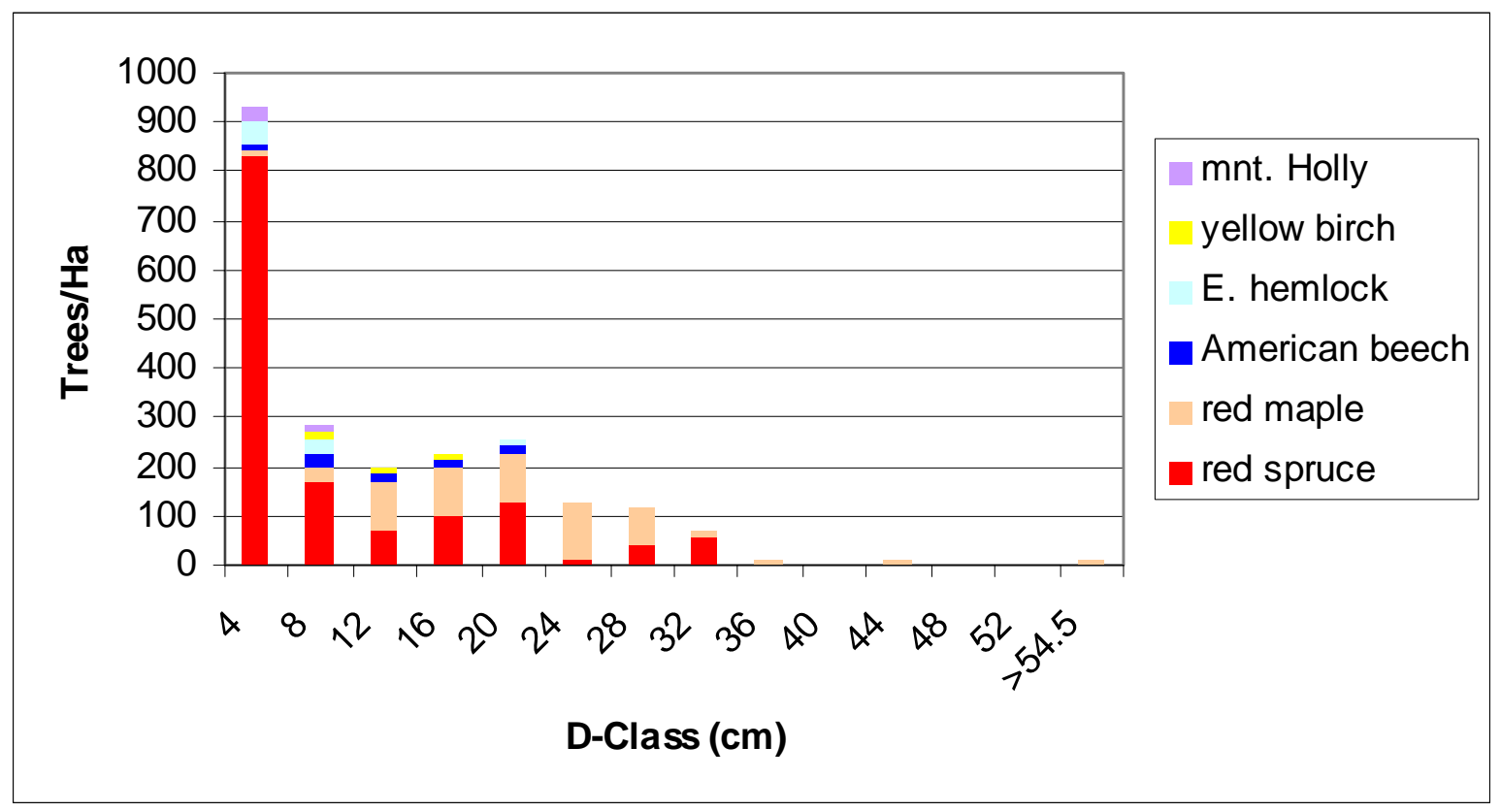

Figure 8. Diameter distribution graph for all species and dbh classes at McGowan Mountain 2003. 

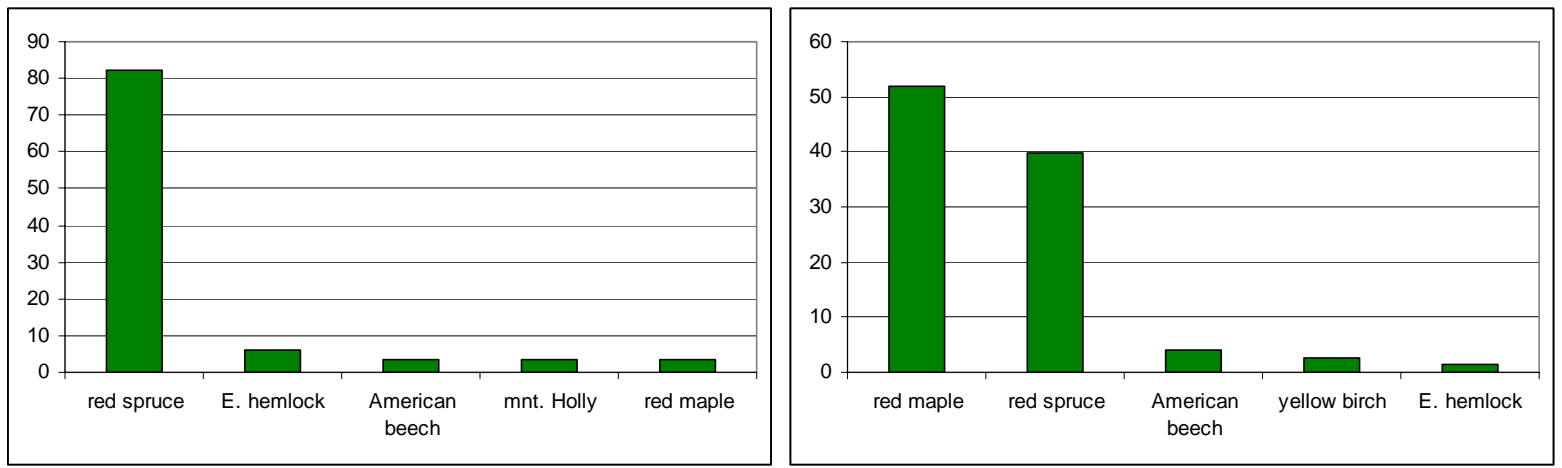

Figure 9. The percent contribution by species to the small diameter classes ( $\leq 8 \mathrm{~cm}$ class) left, and the large diameter classes (> 8 cm class); right, McGowan Mountain, 2004.

Nine species were represented in the tree stratum at the Cranberry study area (Table 5). The stand density was 1800 trees/ha that with a basal area of $43.36 \mathrm{~m}^{2} /$ ha. On the basis of calculated importance values yellow birch (44.1) and red spruce (36.7) were the most important species at the Cranberry site and they were the only species that had importance values greater than or equal to ten. Together they accounted for $91.9 \%$ of the total basal area and $69.9 \%$ of the tallied stems at the site. Red spruce had the greatest density, accounting for $43.7 \%$ of the total stems (789 stems/ha) at the Cranberry site. Yellow birch accounted for $62.1 \%$ of the basal area (26.91 $\left.\mathrm{m}^{2} / \mathrm{ha}\right)$. American beech and striped maple were present as minor constituents of the stand. Collectively they comprised $6.7 \%$ of the total basal area with 300 stems/ha. The remaining species (mountain maple, red maple, mountain holly, sugar maple, and eastern hemlock) accounted for only $1.4 \%$ of the basal area with 243 trees/ha. 
Table 5. Summary of Tree Stratum Data for Cranberry, 2004.

\begin{tabular}{lccccc}
\hline \multicolumn{1}{c}{ Species } & $\begin{array}{c}\text { Basal Area } \\
\mathbf{m}^{2} \text { /ha }\end{array}$ & $\begin{array}{c}\text { Density } \\
\text { trees/ha }\end{array}$ & $\begin{array}{c}\text { Relative } \\
\text { Density }\end{array}$ & \multicolumn{2}{c}{ Relative } \\
Basal Area & IV \\
\hline yellow birch & 26.91 & 471 & 26.2 & 62.1 & 44.1 \\
red spruce & 12.91 & 786 & 43.7 & 29.8 & 36.7 \\
American beech & 2.50 & 129 & 7.1 & 5.8 & 6.5 \\
striped maple & 0.37 & 171 & 9.5 & 0.9 & 5.2 \\
mt. maple & 0.22 & 86 & 4.8 & 0.5 & 2.6 \\
red maple & 0.22 & 71 & 4.0 & 0.5 & 2.2 \\
mt. holly & 0.11 & 43 & 2.4 & 0.2 & 1.3 \\
sugar maple & 0.02 & 29 & 1.6 & 0.0 & 0.8 \\
e. hemlock & 0.10 & 14 & 0.8 & 0.2 & 0.5 \\
\hline \multicolumn{1}{c}{ SUM } & 43.36 & 1800 & 100 & 100 & 100 \\
\hline
\end{tabular}

The diameter distribution for all species and diameter classes at the Cranberry site revealed a reverse J-shaped curve (Figure 10). Trees in the small diameter classes ( $\leq 8 \mathrm{~cm}$ class) had a density of 1414 stems/ha. These stems comprised $78.6 \%$ of the trees tallied at the Cranberry study site. Red spruce (714 trees/ha) dominated the small diameter class and accounted for 50.5\% of the total small stems (Figure 11). Yellow birch (200 trees/ha) accounted for $14.1 \%$ of small stems while striped maple (171 trees/ha) accounted for $12.1 \%$ of small stems. These were the only other species that individually accounted for greater than $10 \%$ of the small diameter class stems. American beech and mountain maple were noteworthy contributing 7.1\% and $6.1 \%$ of the small diameter stems respectively. The remaining species (red maple, mountain holly, sugar maple, and eastern hemlock) were collectively responsible for $10.0 \%$ of the stems with a density of 143 stems/ha.

Trees representing the larger diameter classes $(>8 \mathrm{~cm})$ account for $21.4 \%$ of the total stems tallied at the Cranberry study area. Yellow birch (271 trees/ha) dominated the large diameter stems accounting for $70.4 \%$ of the large stems at the Cranberry site (Figure 11). Red spruce (71 trees/ha) is the second most abundant species. It is responsible for $18.5 \%$ of the large tree stems tallied. Yellow birch and red spruce collectively account for $88.9 \%$ of the large stems. American beech (29 trees/ha) and red maple (14 trees/ha) contribute the remaining $11.1 \%$ of the large stems with 7.4\% and 3.7\% respectively. Yellow birch, red spruce, American beech, and red maple are the only species represented as large trees. Eastern hemlock, mountain holly, 
mountain maple, striped maple, and sugar maple occurred as small stems but were not present as large stems.

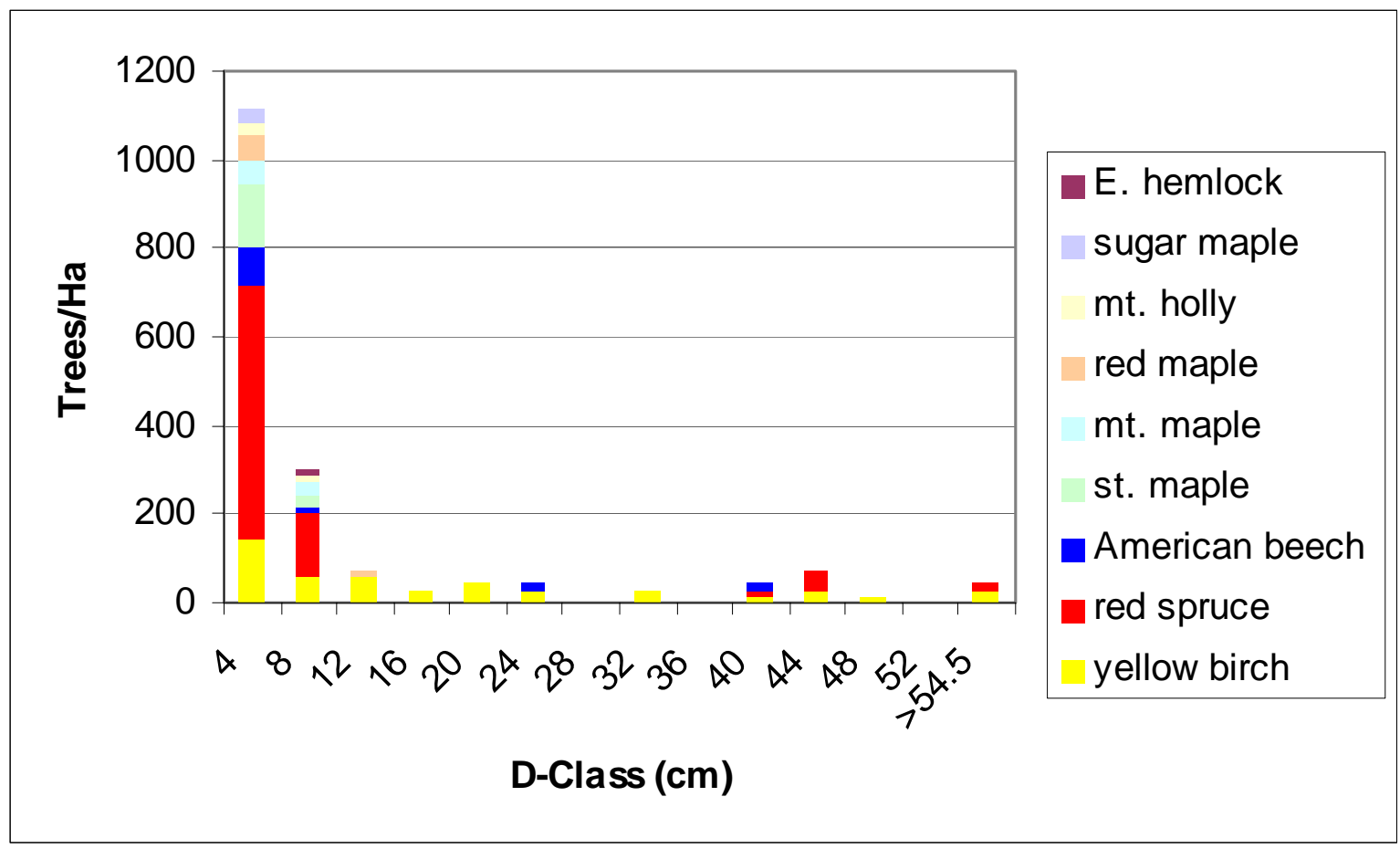

Figure 10. Diameter distribution graph for all species and dbh classes at Cranberry 2004.
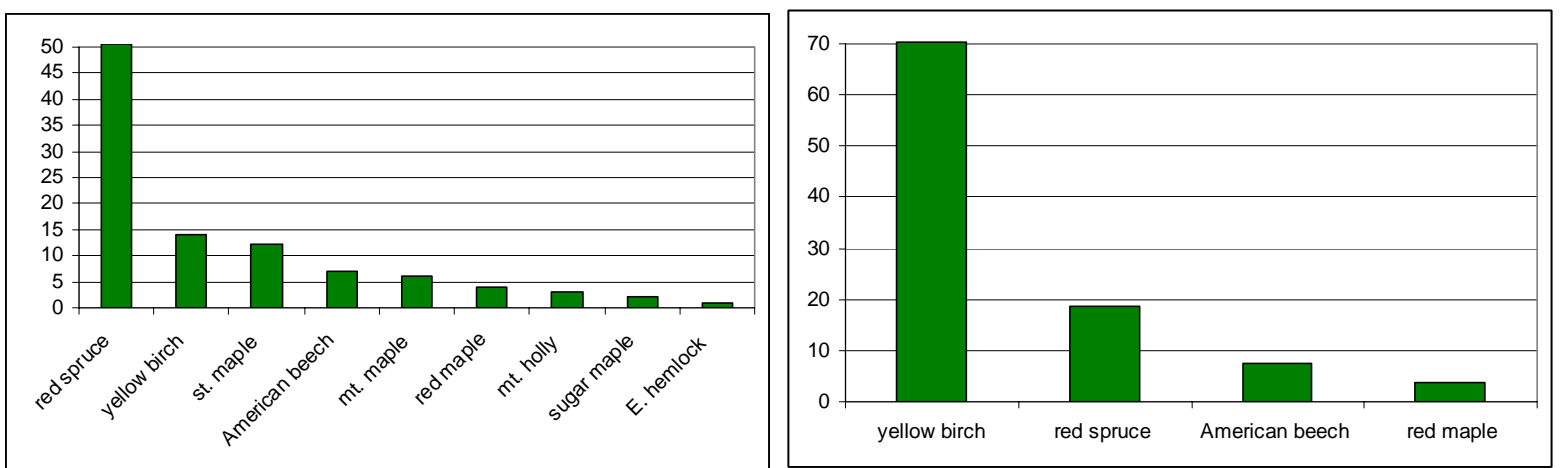

Figure 11 . The percent contribution by species to the small diameter classes ( $\leq 8 \mathrm{~cm}$ class) left, and the large diameter classes (> 8 cm class); right, Cranberry site 2004. 
The sapling stratum at Turkey Run was less diverse than the tree stratum and was dominated by red spruce with a density of 1750 stems per hectare (Table 6). Fifty percent of the species from the tree stratum were represented as saplings. Red spruce accounted for $78 \%$ of the total stems in the sapling class followed by American beech, which comprised 14\% of the sapling stems with a density of 310 stems per hectare. Saplings and trees followed the same trend of decreasing densities from red spruce, American beech, striped maple, and yellow birch. The sapling stratum was composed of shade tolerant species with the exception of yellow birch whose shade tolerance is rated as intermediate.

Table 6. Sapling stratum by species at Turkey Run, 2003.

\begin{tabular}{lcc}
\multicolumn{1}{c}{ Species } & \multicolumn{2}{c}{ Density } \\
stems/ha & IV \\
\hline red spruce & 1750 & 78.5 \\
American beech & 310 & 13.9 \\
striped maple & 120 & 5.4 \\
yellow birch & 30 & 1.3 \\
e. hemlock & 20 & 0.9 \\
\hline \multicolumn{1}{c}{ Total } & 2230 & 100 \\
\hline
\end{tabular}

Only two species, representing 33.3\% of the tree stratum species, were present in the sapling stratum at McGowan Mountain, and was overwhelmingly dominated by red spruce. Red spruce accounted for $98.5 \%$ of the saplings present at the site (Table 7) with a density of 943 stems per hectare. Mountain holly or mountain winterberry (Ilex montana) was the only other sapling species present and it only composed $1.5 \%$ of the stems with a density of 14 stems per hectare.

Table 7. Sapling stratum by species at McGowan Mountain, 2004.

\section{Density}

\begin{tabular}{lcc}
\multicolumn{1}{c}{ Species } & stems/ha & IV \\
\hline mt. holly & 14 & 1.5 \\
red spruce & 943 & 98.5 \\
\hline \multicolumn{1}{c}{ Total } & 957 & 100 \\
\hline
\end{tabular}


The sapling stratum at the Cranberry site consisted of seven species representing $77.8 \%$ of the species from the tree stratum. Red spruce was the dominant sapling accounting for $70.1 \%$ of the saplings (Table 8 ) and yellow birch accounted for $13.6 \%$ of the saplings. The remaining species individually accounted for less than ten percent of the sapling stratum. The sapling stratum was dominated by shade tolerant species.

Table 8. Sapling stratum by species at Cranberry, 2004.

\begin{tabular}{lcc}
\hline \multicolumn{1}{c}{ Species } & Density \\
stems/ha & IV \\
\hline red spruce & 1771 & 70.1 \\
yellow birch & 343 & 13.6 \\
striped maple & 171 & 6.8 \\
American beech & 143 & 5.6 \\
mt. holly & 43 & 1.7 \\
mt. maple & 43 & 1.7 \\
red maple & 14 & 0.6 \\
\hline \multicolumn{1}{c}{ Total } & 2529 & 100 \\
\hline
\end{tabular}

The shrub stratum at the sites was relatively non-diverse. Collectively the shrub stratum at all three study areas contained only two species, predominantly Rhododendron maximum at two of the sites (Table 9). The extent of the shrub stratum varied between sites. McGowan Mountain had the most dense shrub stratum with a density of Rhododendron maximum of 8457 stems per hectare. The shrub stratum at Turkey Run was much less dense with a Rhododendron density of 800 stems per hectare. Rhododendron was absent from the shrub stratum at Cranberry and the only species present was hobblebush (Viburnum alnifolium) at 1200 stems per hectare.

Table 9. Summary of shrub stratum.

\begin{tabular}{llcc}
\hline \multicolumn{1}{c}{ Site } & \multicolumn{1}{c}{ Species } & $\begin{array}{c}\text { Density } \\
\text { stems/ha }\end{array}$ & IV \\
\hline Turkey & Great Rhododendron & 800 & 100 \\
McGowan & Great Rhododendron & 8457 & 100 \\
Cranberry & Hobblebush & 1200 & 100 \\
\hline
\end{tabular}


The seedling stratum differed between sites (Table 10). Red spruce was the only species represented in the seedling stratum at Turkey Run, where it obtained a density of 6000 stems per hectare. Red spruce, red maple and black cherry were the only three species represented in the seedling stratum at McGowan Mountain with red maple seedlings being the most abundant at 15714 stems per hectare. Red spruce followed with 12857 stems per hectare and black cherry was the only other seedling species present with 1429 stems per hectare. The Cranberry study area harbored the most diverse seedling stratum. Seven species were present at the Cranberry study area. Red spruce was the most abundant seedling accounting for $43.8 \%$ of the seedlings with a density of 10000 stems per hectare. Mountain maple was the second most abundant comprising $18.8 \%$ of the total seedlings, followed by American beech contributing an additional $12.5 \%$. The remaining species individually accounted for $6.3 \%$ of the seedlings. The total density of red spruce seedlings and the importance values of red spruce seedlings were investigated with the ANOVA procedure. Although the sites differed widely, both quantitatively and qualitatively, the analysis of variance failed to detect any significant difference between sites for the variables tested.

Table 10. 2003, 2004 Seedling densities, stems per hectare; (importance values) by site. Site Species Turkey McGowan Cranberry

\begin{tabular}{lrrr} 
red spruce & $6000(100) 12857(42.9)$ & $10000(43.8)$ \\
red maple & $15714(52.4)$ & $1429(6.3)$ \\
mt. maple & $4286(18.8)$ \\
American beech & & $4285(12.5)$ \\
striped maple & & $2857(6.3)$ \\
sugar maple & $1429(6.3)$ \\
yellow birch & & $1429(6.3)$ \\
black cherry & \multicolumn{1}{c}{$1429(6.3)$} \\
\hline \multicolumn{1}{c}{ sum } & $6000(100) 30000(100)$ & $22857(100)$ \\
\hline
\end{tabular}

The ground cover was highly variable between sites. Coarse woody debris, bryophytes, and Dryopteris spp. were the only types of cover that were common among all three study areas (Table 11). Coarse woody debris was the most prevalent type of cover at both Turkey Run and 
McGowan Mountain. Bryophytes were the second most prevalent type of cover followed by Dryopteris spp. at both Turkey Run and McGowan Mountain. These three types of cover were also dominant at the Cranberry site however with slightly different rankings when compared to Turkey Run and McGowan Mountain. Bryophytes asserted the most dominance as a cover type at the Cranberry site. Dryopteris spp. and coarse woody debris followed in decreasing percentage of cover.

Table 11. 2003, 2004 Percent ground cover by site.

Type Site Turkey McGowan Cranberry

\begin{tabular}{lccc}
\hline Course woody debris & 17.7 & 14.5 & 20.4 \\
Bryophytes & 8.9 & 7.0 & 29.8 \\
Dryopteris spp. & 7.5 & 1.4 & 25.2 \\
Oxalis montana & 0.6 & & 2.0 \\
Mitchella repens & 0.1 & & 0.2 \\
Rocks & 2.1 & & \\
Dennstaedtia spp. & 5.8 & & \\
Aster accuminatus & & & 0.2 \\
Canada Lilly & & 0.4 & \\
\hline
\end{tabular}




\section{$\underline{\text { Temporal Patterns Across Sites and Transects }}$}

The Turkey Run, McGowan Mountain, and Cranberry sites represent three distinct ecological situations differing by the frequency and extent of disturbance experienced. The following results illustrate the general patterns occurring for red spruce forest zones at each transect. These results incorporate unpublished data collected by Adams and Stephenson (1994) supplemented by data collected in 2003 and 2004. The temporal patterns illustrated for Turkey Run and McGowan Mountain cover a period of time spanning eleven years, while the patterns for the Cranberry site span a period of ten years.

When data from all forest zones were combined the density of red spruce trees showed an increasing trend at all sites over time (Figure 12). McGowan Mountain realized the greatest increase in red spruce density followed by Turkey Run with the addition of 729 and 660 trees per hectare, respectively. The increase of red spruce density at Turkey Run from 650 to 1310 (Figure. 12) trees per hectare was the only increase found to be statistically significant $(\mathrm{P}=$ 0.0479). The Cranberry site experienced the lowest magnitude of red spruce increase with an increase of 200 trees per hectare. By contrast, the density of hardwood stems showed an overall decrease for the McGowan Mountain and Turkey Run sites (Figure 13). McGowan Mountain lost 157 hardwood trees per hectare and hardwoods decreased at Turkey Run by 140 trees per hectare. Hardwood densities at the Cranberry site remained fairly constant showing a slight increase in density of 29 trees per hectare. But in this case the increase of red spruce trees was much greater than the addition of hardwood species. 


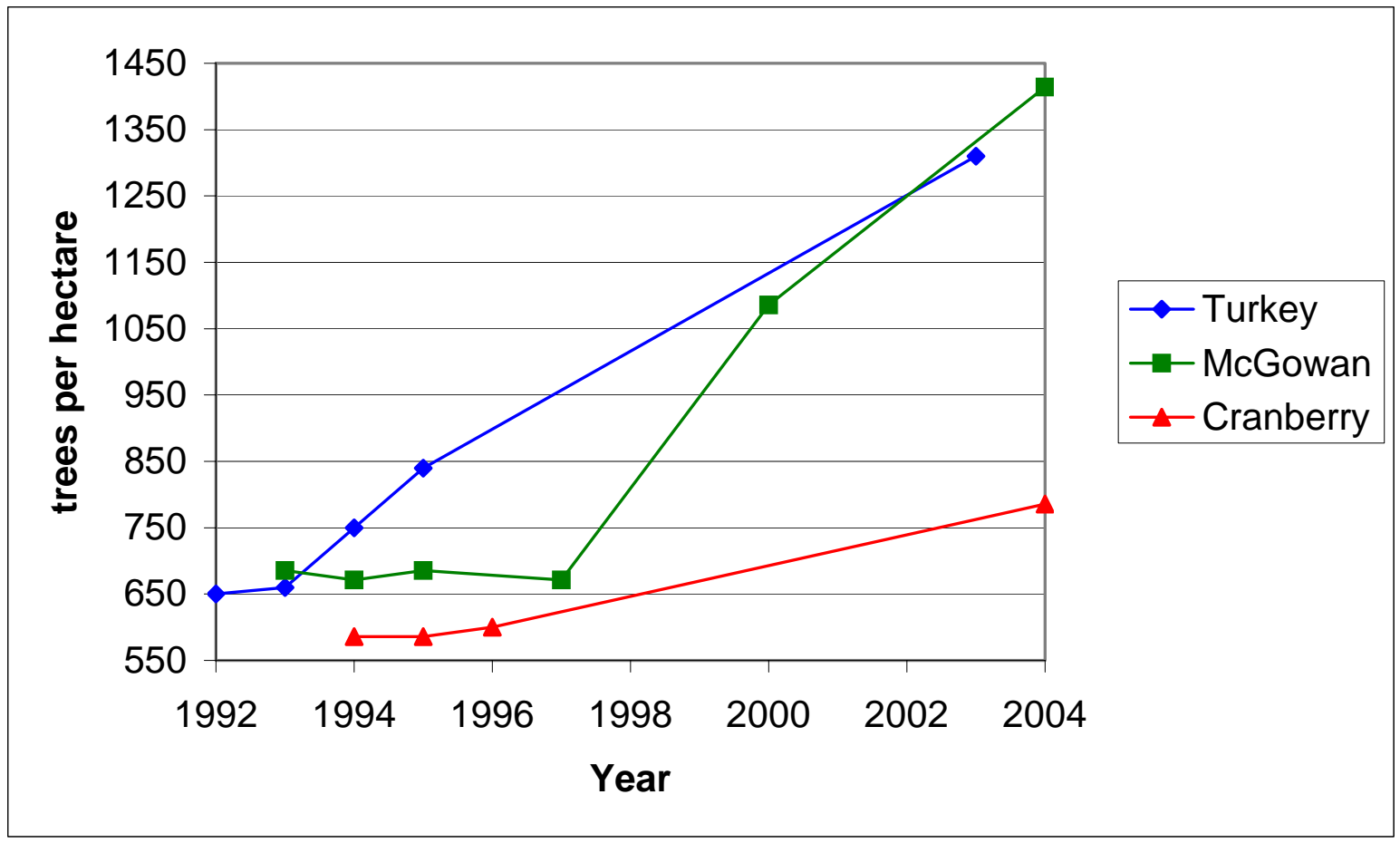

Figure 12. The temporal pattern of red spruce tree density for all zones pooled (trees $\geq 2.5 \mathrm{~cm}$ ).

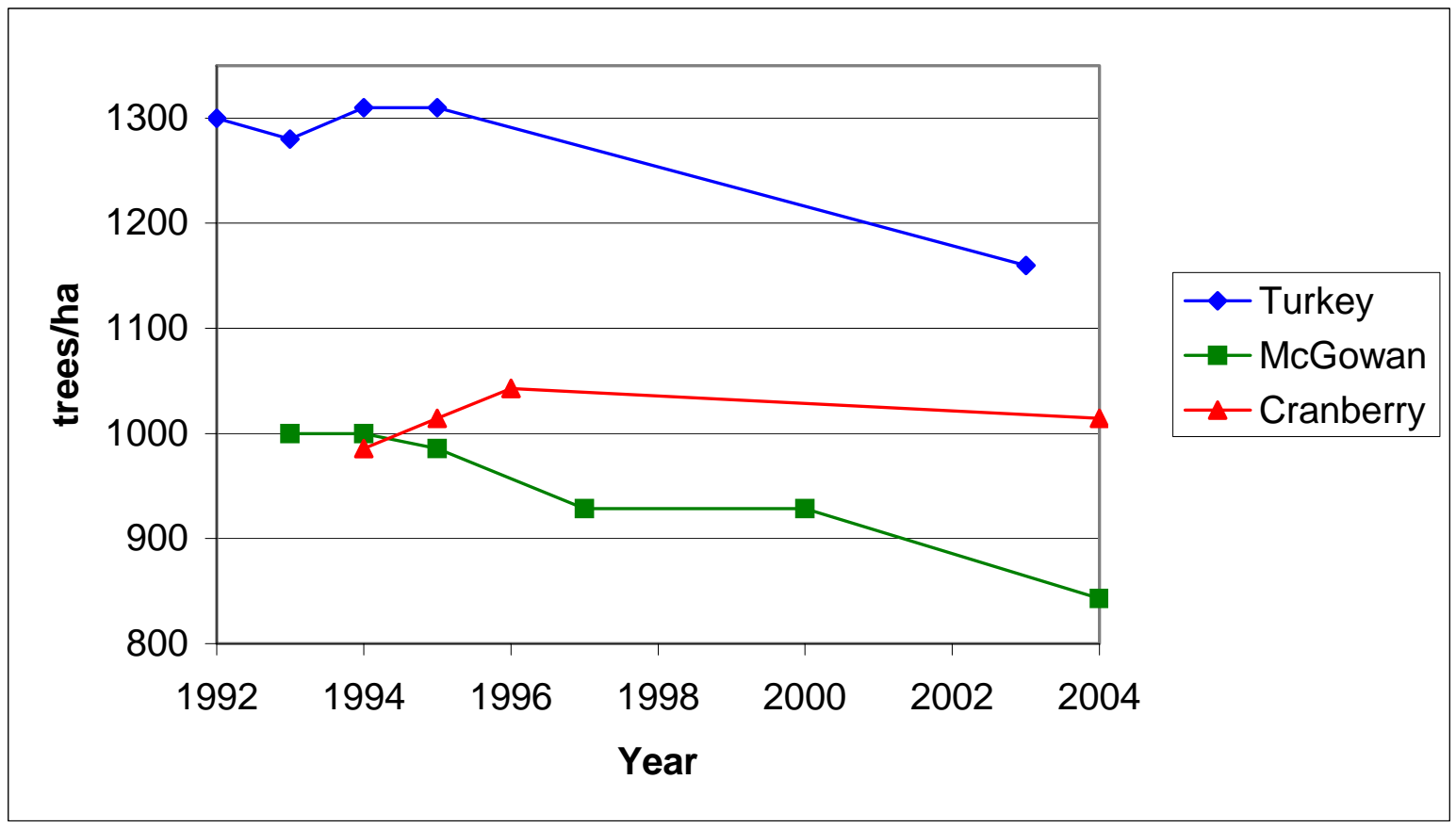

Figure 13. The temporal pattern of hardwood tree density for all zones pooled (trees $\geq 2.5 \mathrm{~cm}$ ). 
The temporal trends for the relative density, relative basal area and importance values for spruce and hardwood trees are presented for each site in Figures 19 - 24. Although, apparent trends were present these variables were not found to be statistically significant. The relative density of red spruce trees revealed an increasing trend at each site (Figure 14). The McGowan Mountain and Turkey Run sites experienced the most pronounced change. The relative density of red spruce at McGowan Mountain showed a 22\% increase followed by Turkey Run with a $20 \%$ increase and Cranberry with an increase of $6 \%$. In turn, the relative density of hardwood stems experienced a decreasing pattern at all three sites (Figure 15).

The relative basal area of red spruce has experienced an increasing trend of 7\% at Turkey Run and 3\% at McGowan Mountain while Cranberry showed a 9\% decrease (Figure 16). As shown in Figure 17, the relative basal area of hardwoods decreased at Turkey Run and McGowan Mountain, while experiencing a small increase at the Cranberry site.

The importance values for red spruce increased at two sites (Turkey Run and McGowan Mountain) and remained almost constant at the Cranberry site (Figure 18). The importance values for red spruce increased by 13 for Turkey Run and 12 for McGowan Mountain and had a $1 \%$ decrease at Cranberry. In turn, hardwoods experienced a decrease at Turkey Run and McGowan Mountain, while displaying a 1\% increase at the Cranberry site (Figure 19). 


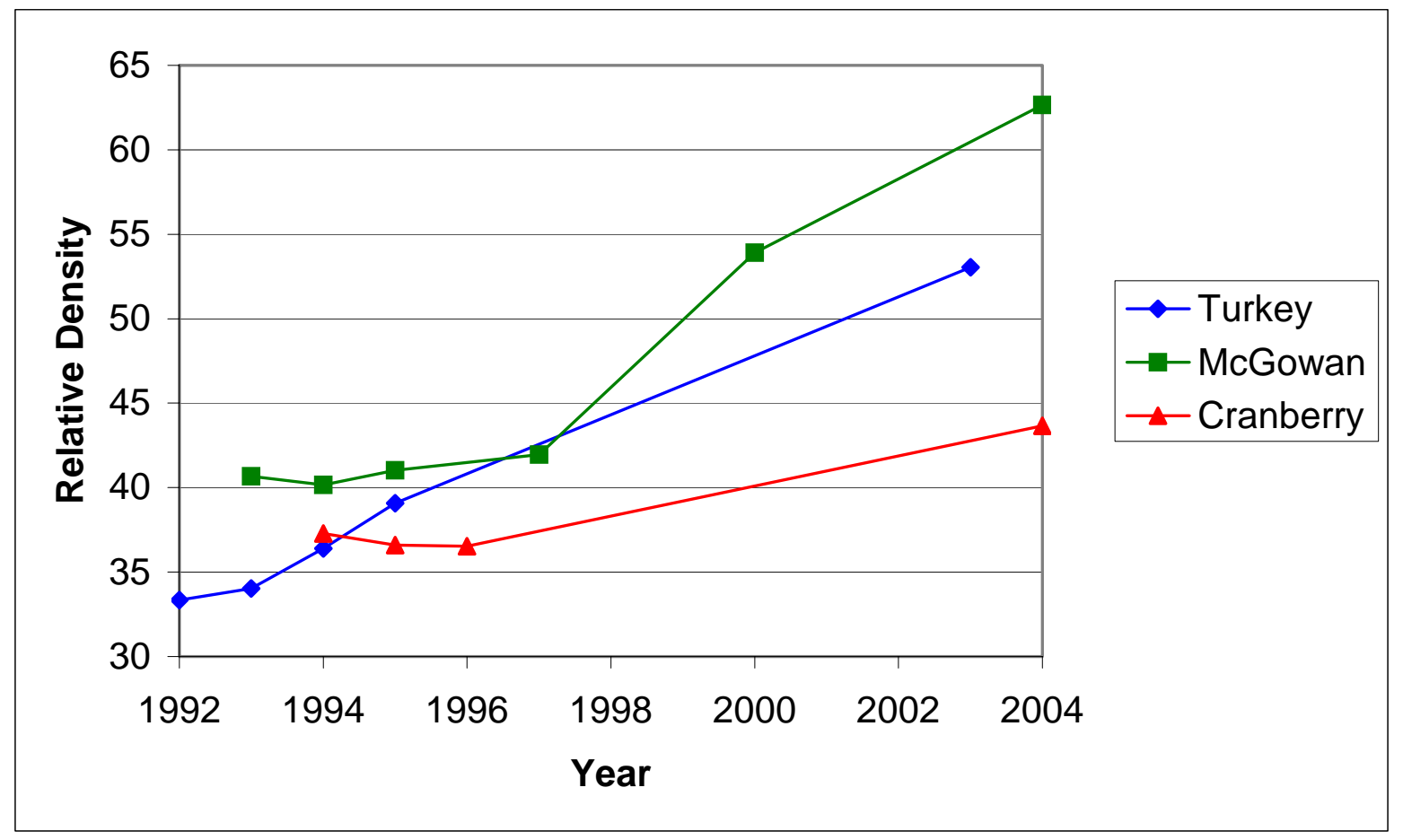

Figure 14. The temporal pattern of red spruce tree relative density for all zones pooled (trees $\geq$ $2.5 \mathrm{~cm}$ ).

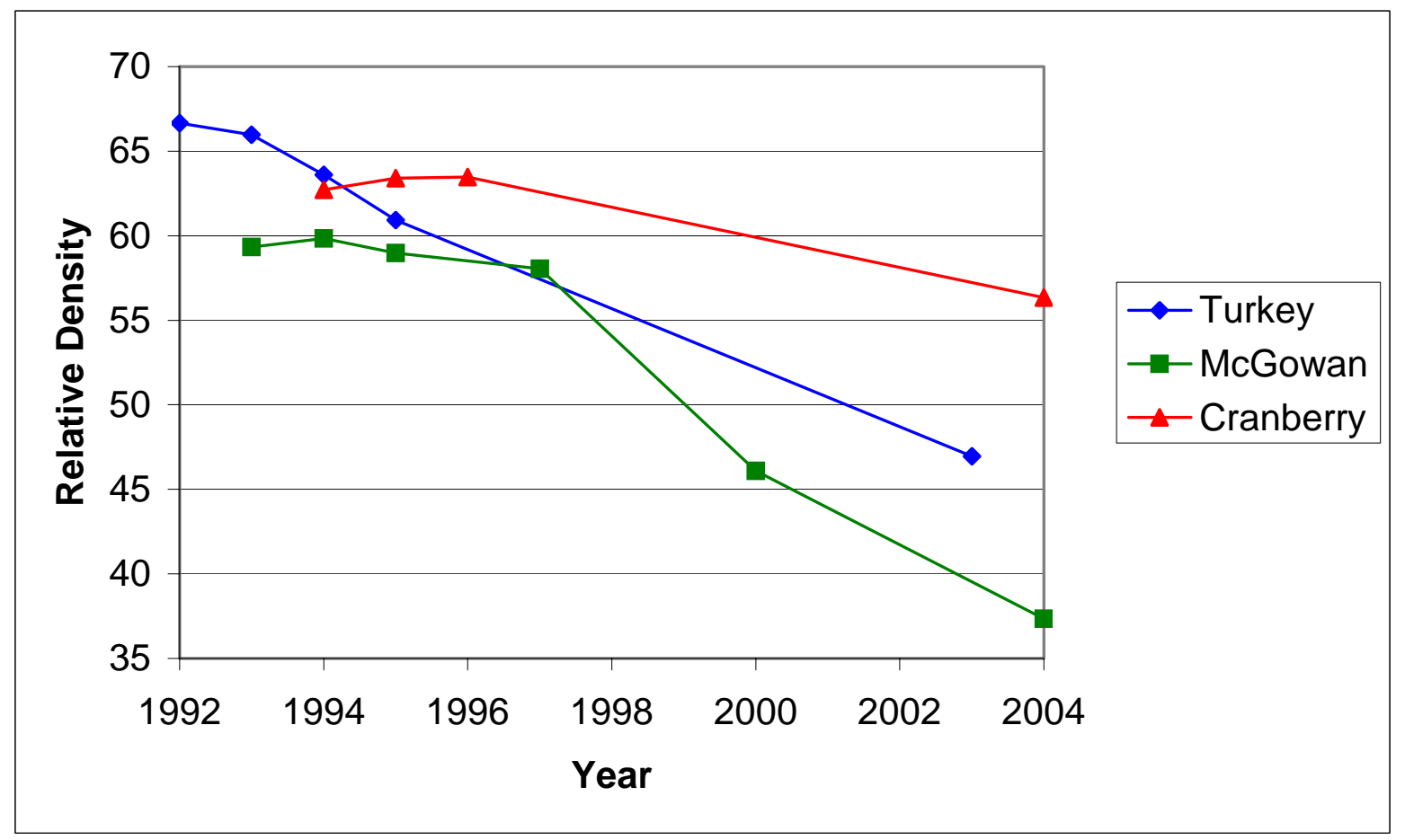

Figure 15. The temporal pattern of hardwood tree relative density for all zones pooled (trees $\geq$ $2.5 \mathrm{~cm}$ ). 


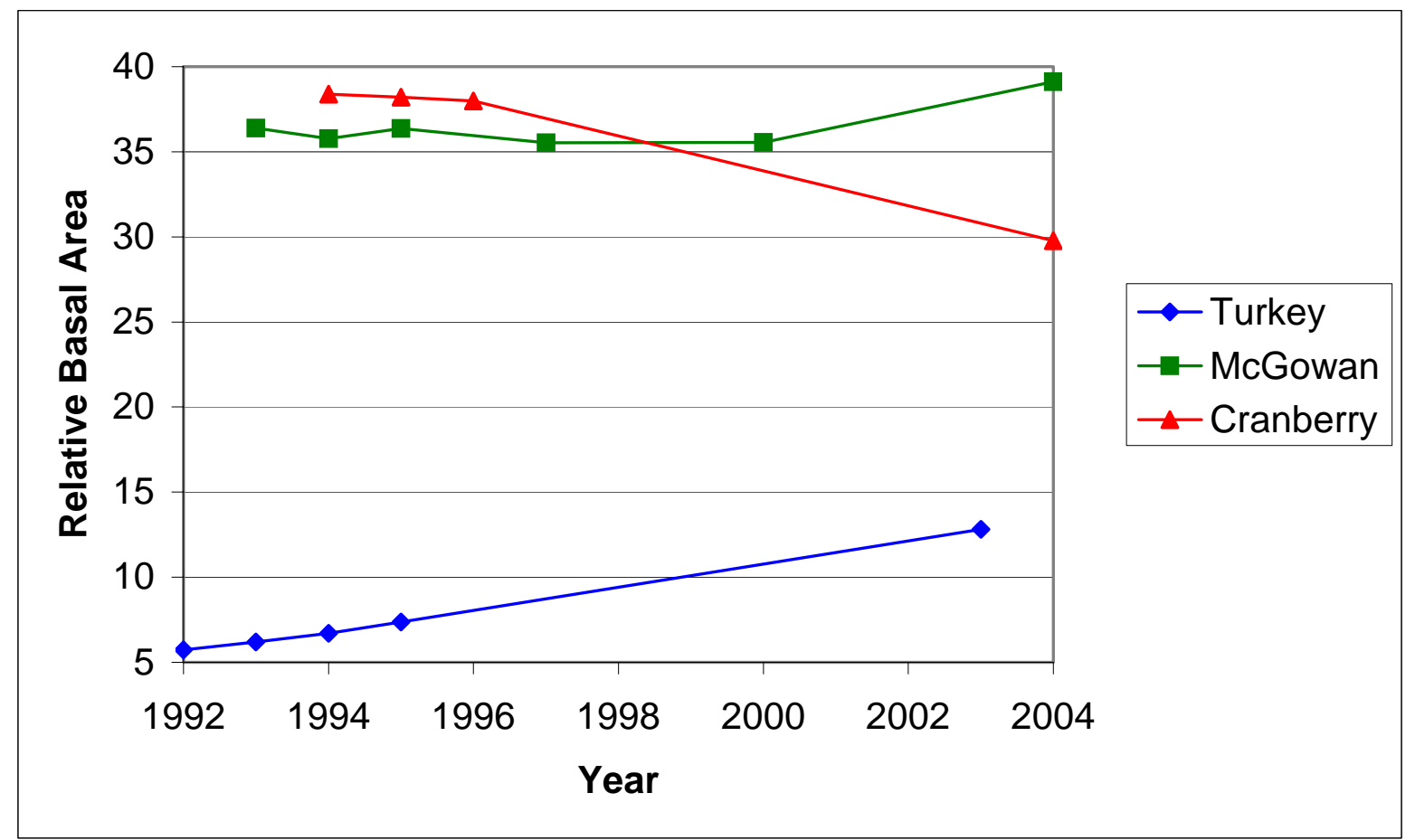

Figure 16. The temporal pattern of red spruce tree relative basal area for all zones pooled (trees $\geq 2.5 \mathrm{~cm}$ ).

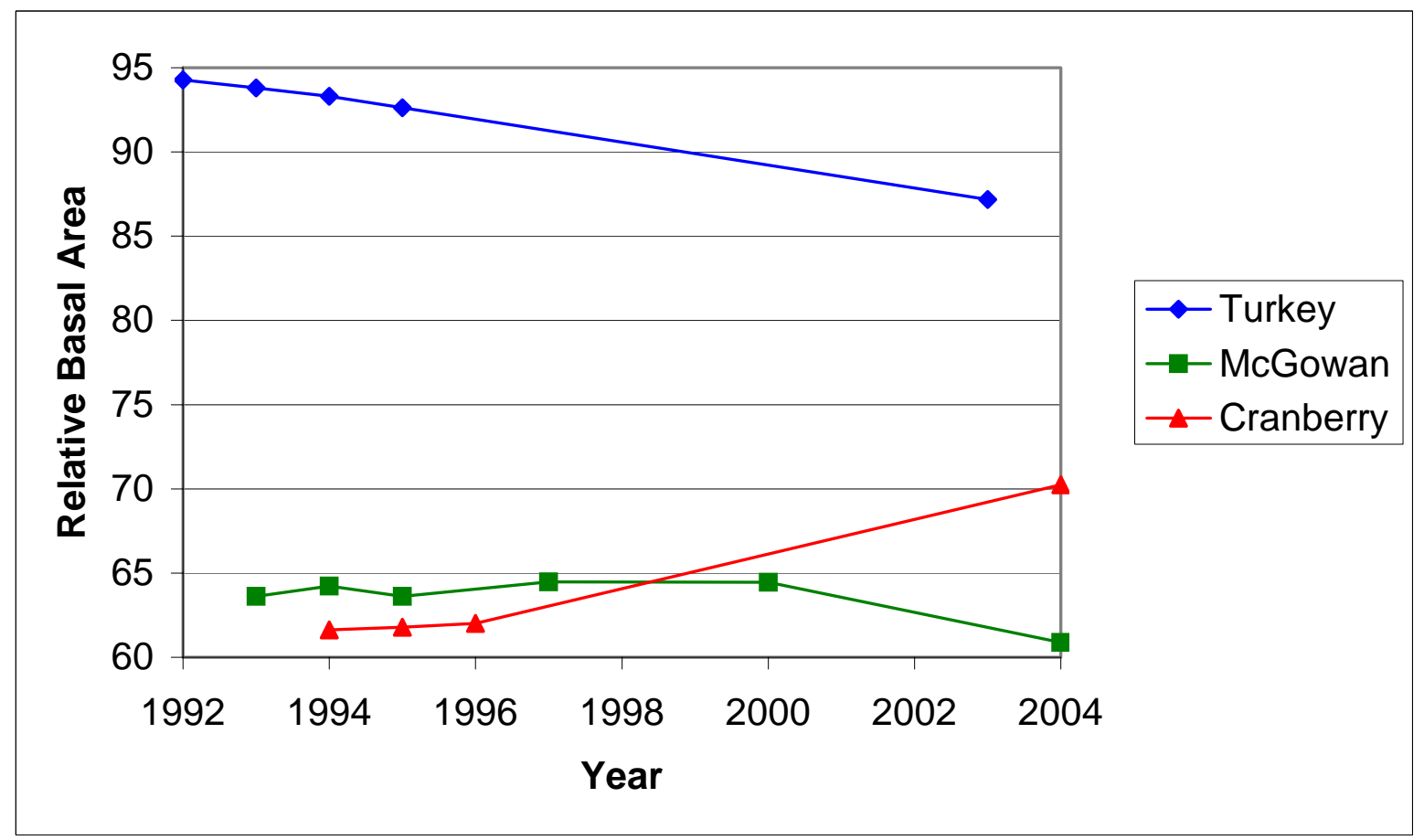

Figure 17. The temporal pattern of hardwood tree relative basal area for all zones pooled (trees $\geq$ $2.5 \mathrm{~cm}$ ). 


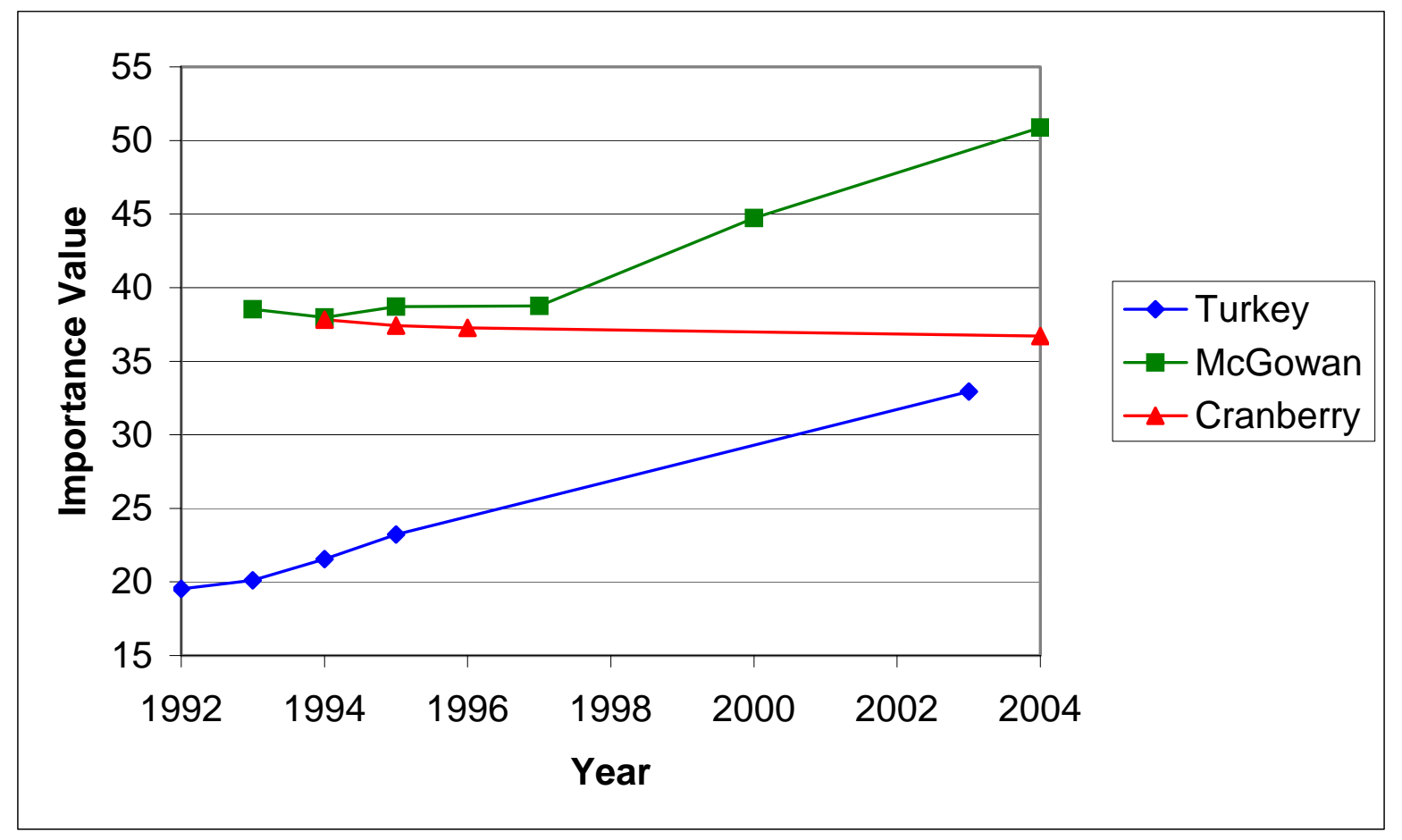

Figure 18. The temporal pattern of red spruce tree importance values for all zones pooled (trees $\geq 2.5 \mathrm{~cm}$ ).

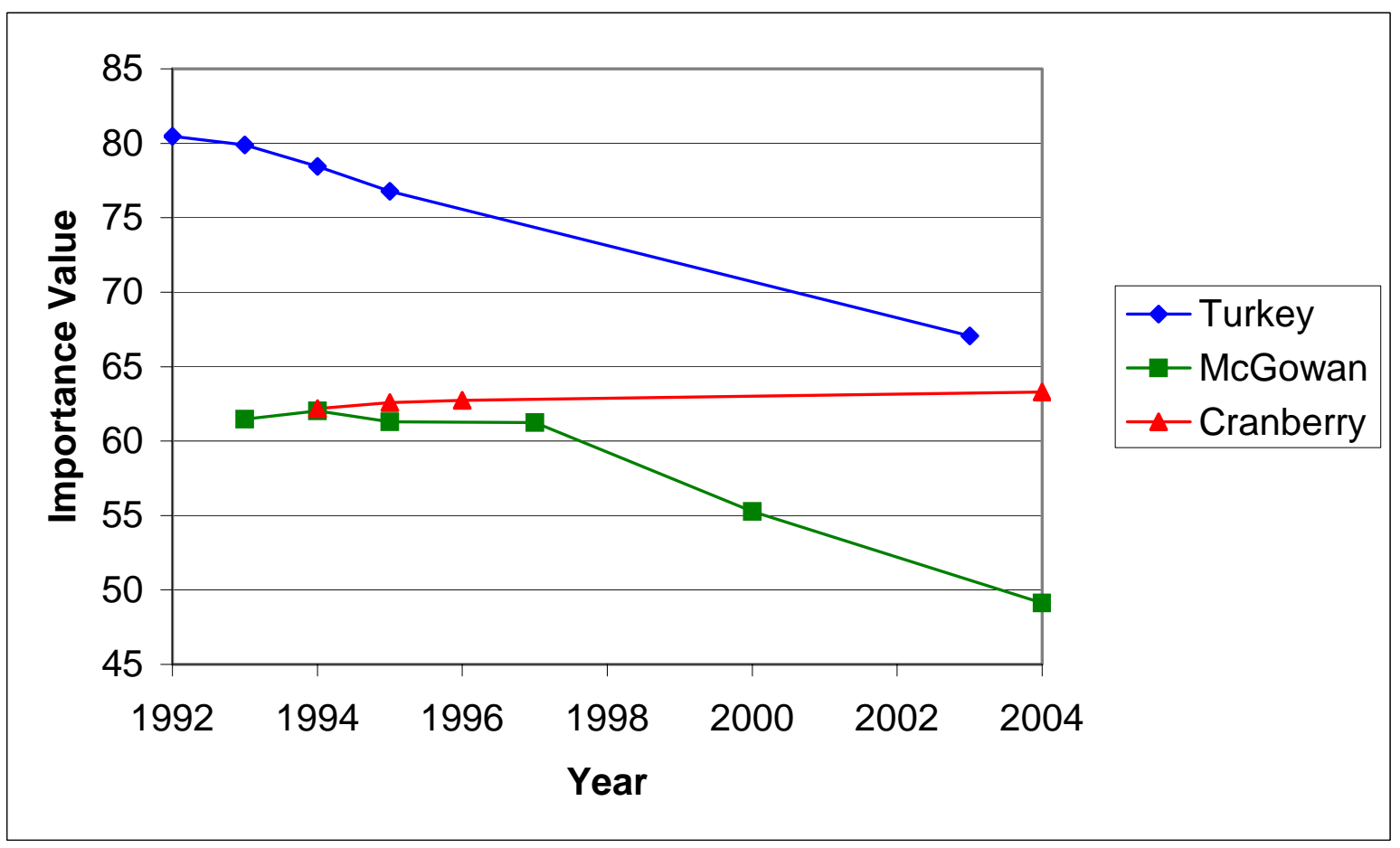

Figure 19. The temporal pattern of hardwood tree importance values for all zones pooled (trees $\geq 2.5 \mathrm{~cm})$. 
The variables for saplings of red spruce stems per hectare, red spruce importance values, hardwood stems per hectare, and hardwood importance values were tested using the ANOVA procedure and were not found to be statistically significant. However, there are trends are apparent at the sites. The McGowan Mountain and Turkey Run sites both experienced a net decline of red spruce saplings over the ten-year period, while the Cranberry stand revealed a net increase of red spruce sapling densities over nine years (Figure 20). Red spruce densities decreased by 300 stems per hectare at McGowan Mountain and by 60 stems per hectare at Turkey Run. Red spruce sapling densities increased by 143 stems per hectare at the Cranberry study site. The temporal trends of red spruce trees during the same time periods for these sites revealed substantial increasing densities (Figure 12).

The densities for all saplings of hardwood species revealed a decreasing pattern over time (Figure 21) at all three sites. The Cranberry study site experienced the largest decrease of 386 stems per hectare. Turkey Run followed with a decline of 210 stems per hectare and McGowan Mountain with a decrease of 43 stems per hectare. Figure 13 also revealed a declining density of hardwood tree stems over time at Turkey Run and McGowan Mountain. The net increase of red spruce was 200 trees per hectare while the net increase of hardwoods was 29 trees per hectare (Figures 12 and 13). 


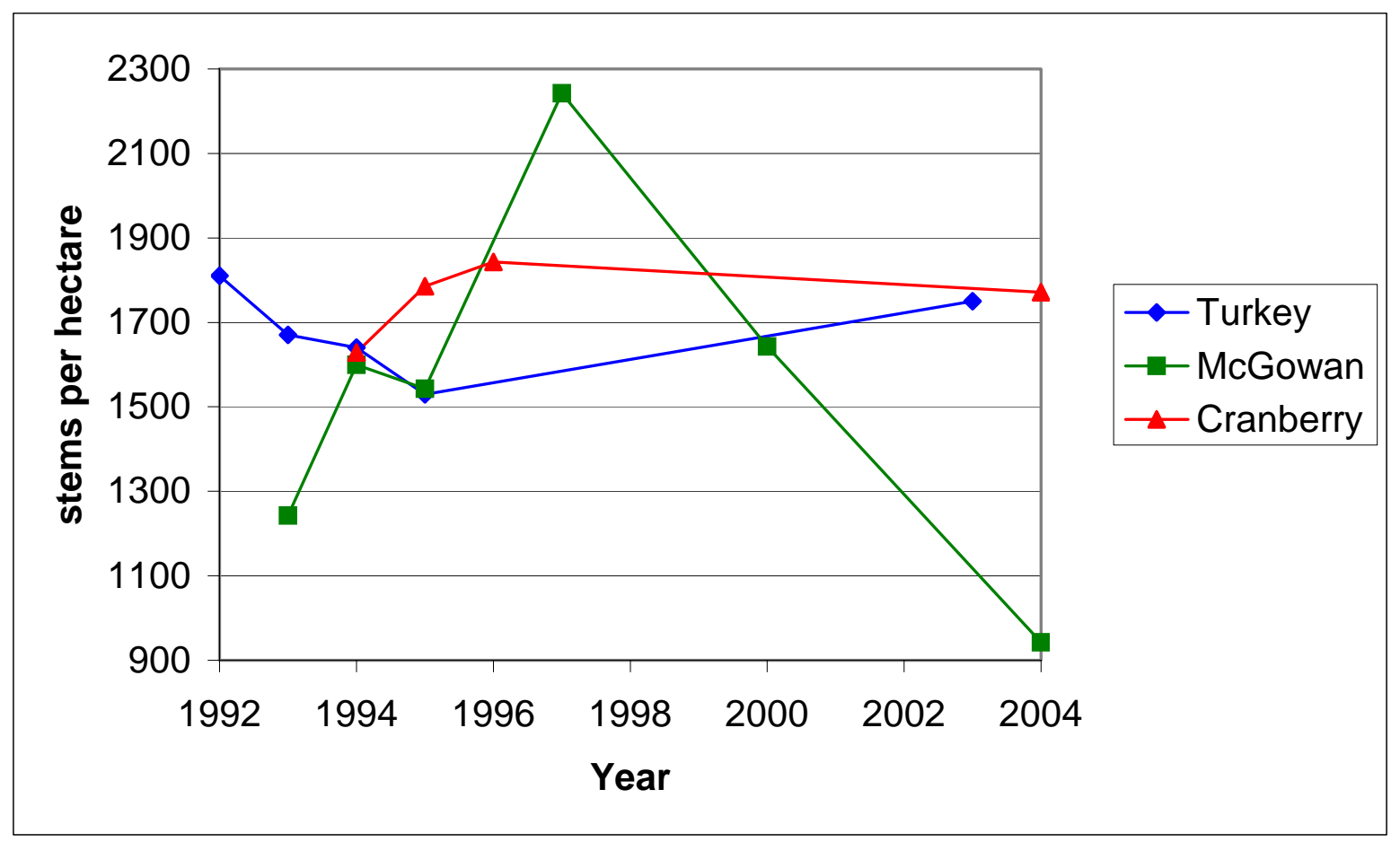

Figure 20. The temporal pattern of red spruce sapling densities for all zones pooled.

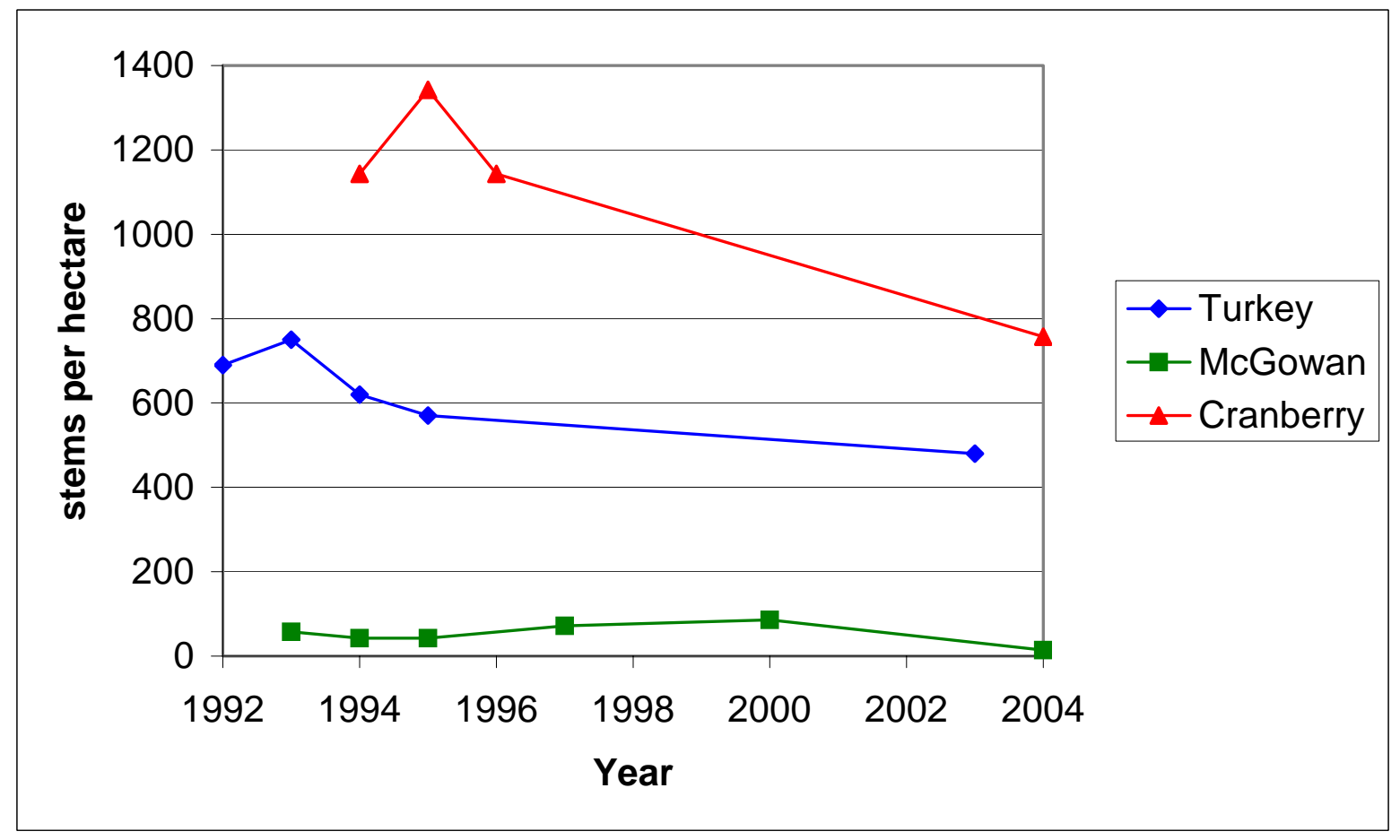

Figure 21. The temporal pattern of hardwood sapling densities for all zones pooled. 
The calculated importance values for red spruce saplings had an increasing trend at all three sites (Figure 22). The Cranberry study site experienced the greatest increase in importance for red spruce saplings. The importance value for red spruce saplings at Cranberry increased by 11, followed by an increase of 6 at Turkey Run, while McGowan experienced an increase of 3. 


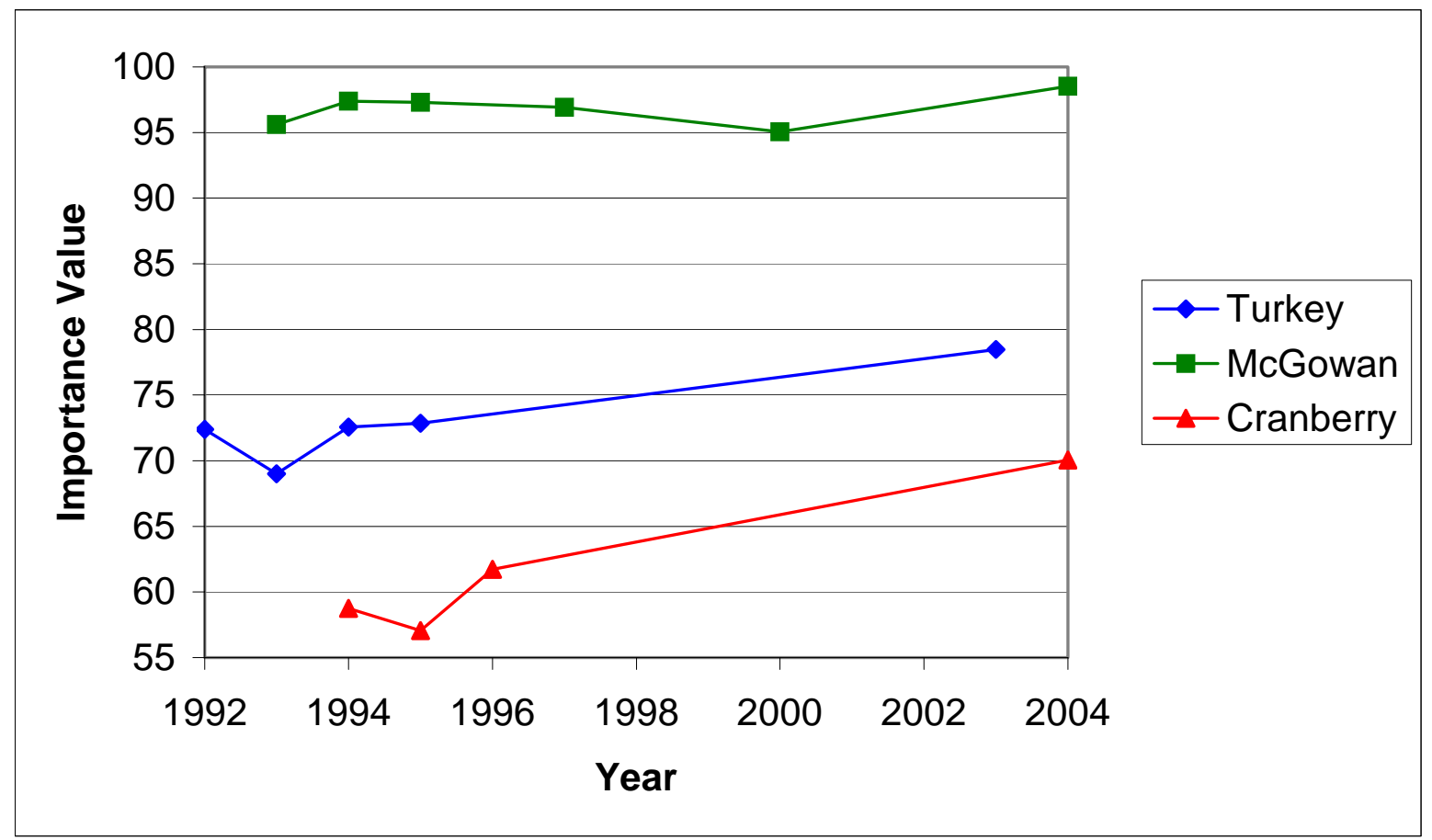

Figure 22. The temporal pattern of importance values for red spruce saplings for all zones pooled.

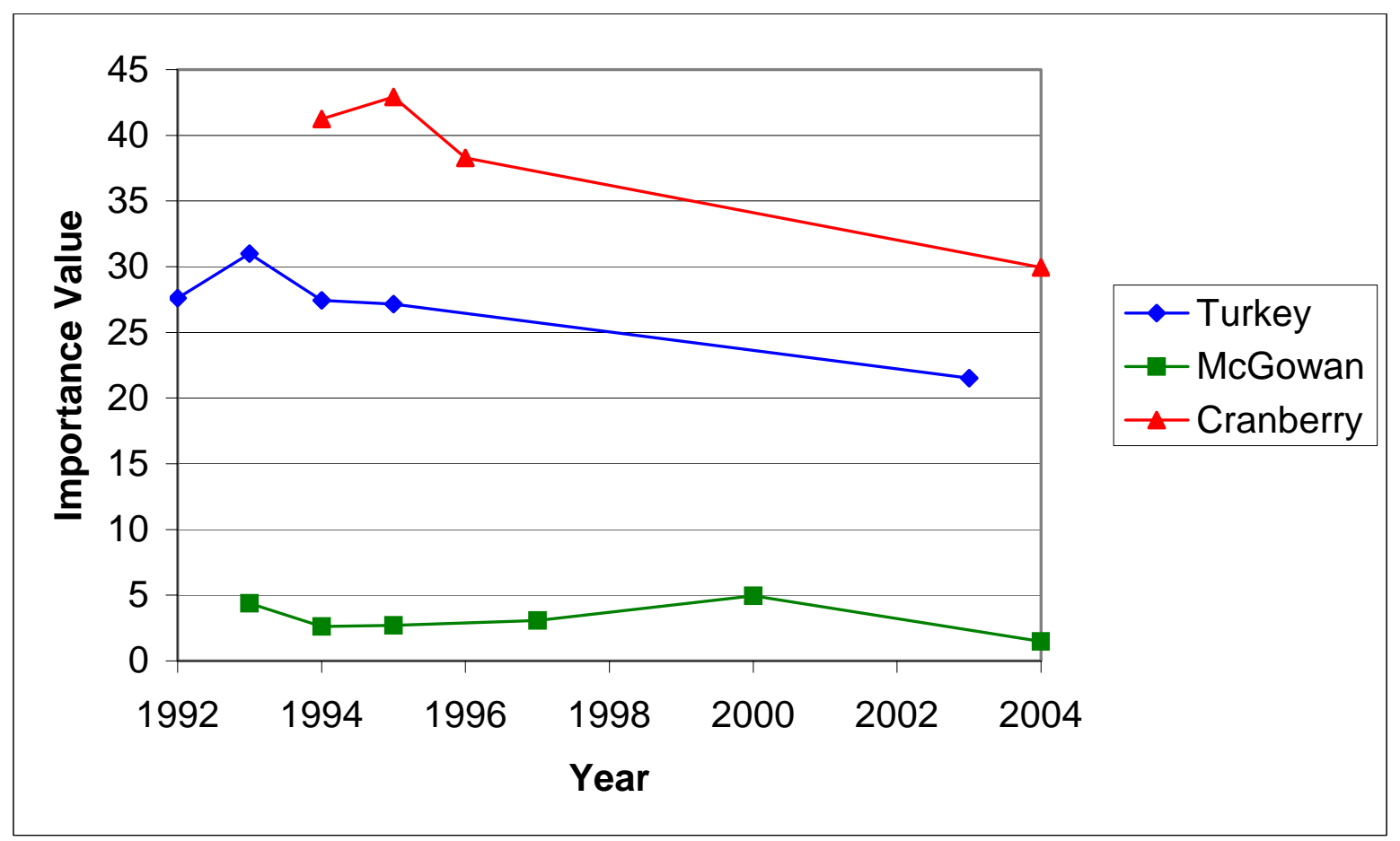

Figure 23. The temporal pattern of importance values of hardwood saplings for all zones pooled. 
The overall density of red spruce seedlings for all size classes combined among the three study sites generally displayed an increasing trend in density (Figure 24). The McGowan Mountain site experienced a net increase of 5714 stems per hectare, followed by the Cranberry and Turkey Run sites, with increasing densities of 2143 and 2000 stems per hectare respectively. The total stems per hectare and the importance value for red spruce seedlings (all size classes combined) were tested using ANOVA, however the changes were not found to be significant.

By contrast, the densities of hardwood seedlings showed a general decrease at each site over time (Figure 25). Turkey Run realized the greatest reduction of 16500 stems per hectare, which was found to be statistically significant at the 0.05 level $(\mathrm{P}=0.0083)$, followed by the McGowan Mountain site decreasing by 6429 stems per hectare and the Cranberry site decreasing by 2857 stems per hectare.

The decreasing hardwood seedling densities and increasing red spruce seedling density resulted in an increasing importance of red spruce seedlings. The calculated importance value for red spruce seedlings increased at all sites with time (Figure 26). The importance value for red spruce seedlings increased by 94 at the Turkey Run site representing the most dramatic increase of any site sampled. The red spruce seedling importance value experienced an increase of 38 at McGowan Mountain and an increase of 20 at the Cranberry site. Conversely, the importance of hardwood seedlings experienced decreasing trends at all sites (Figure 27). The decrease of importance values for hardwood stems dropped by 94, which tested significant with the ANOVA procedure $(\mathrm{P}<0.0001)$. 


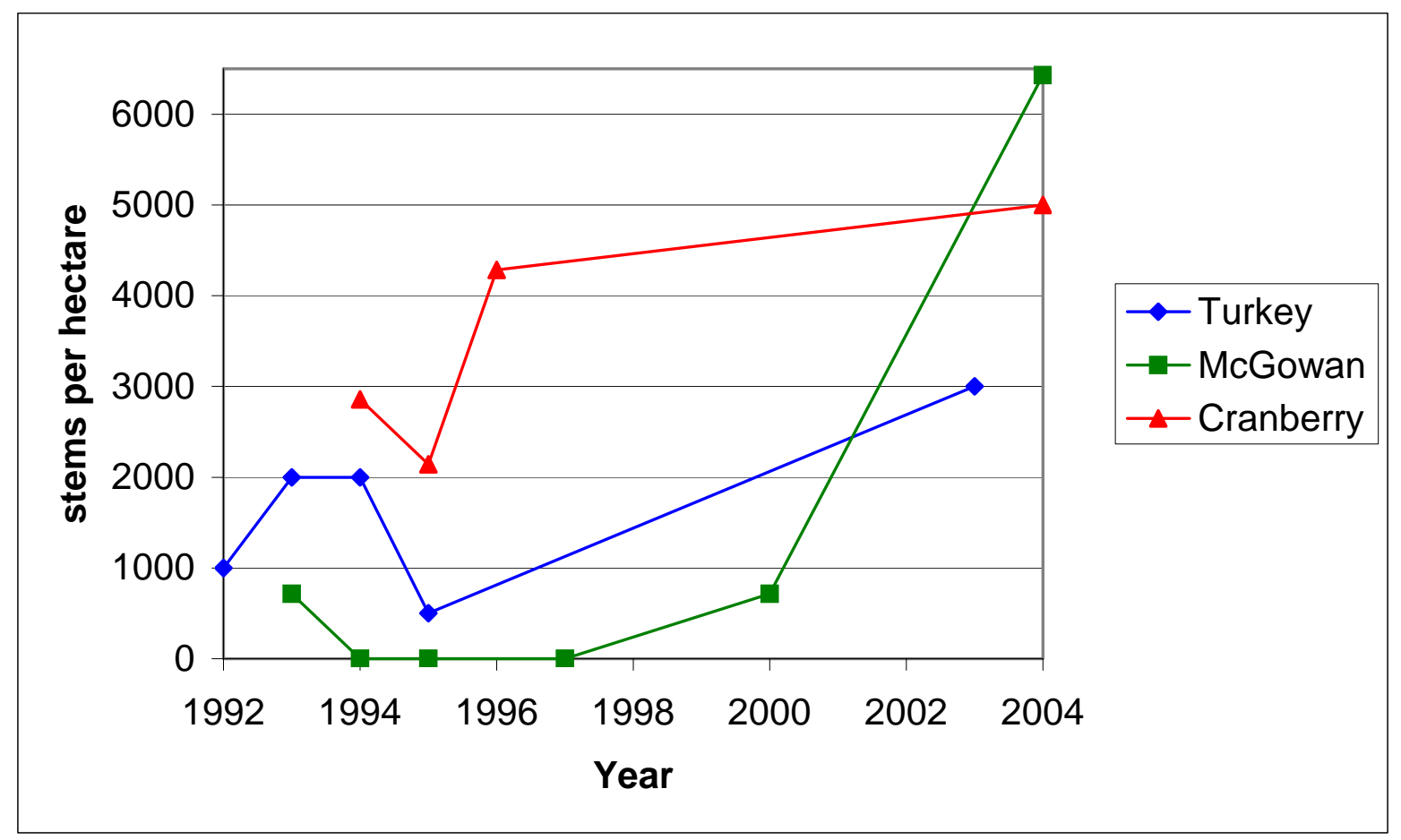

Figure 24. The temporal pattern of red spruce seedling densities for all size classes and forest zones combined.

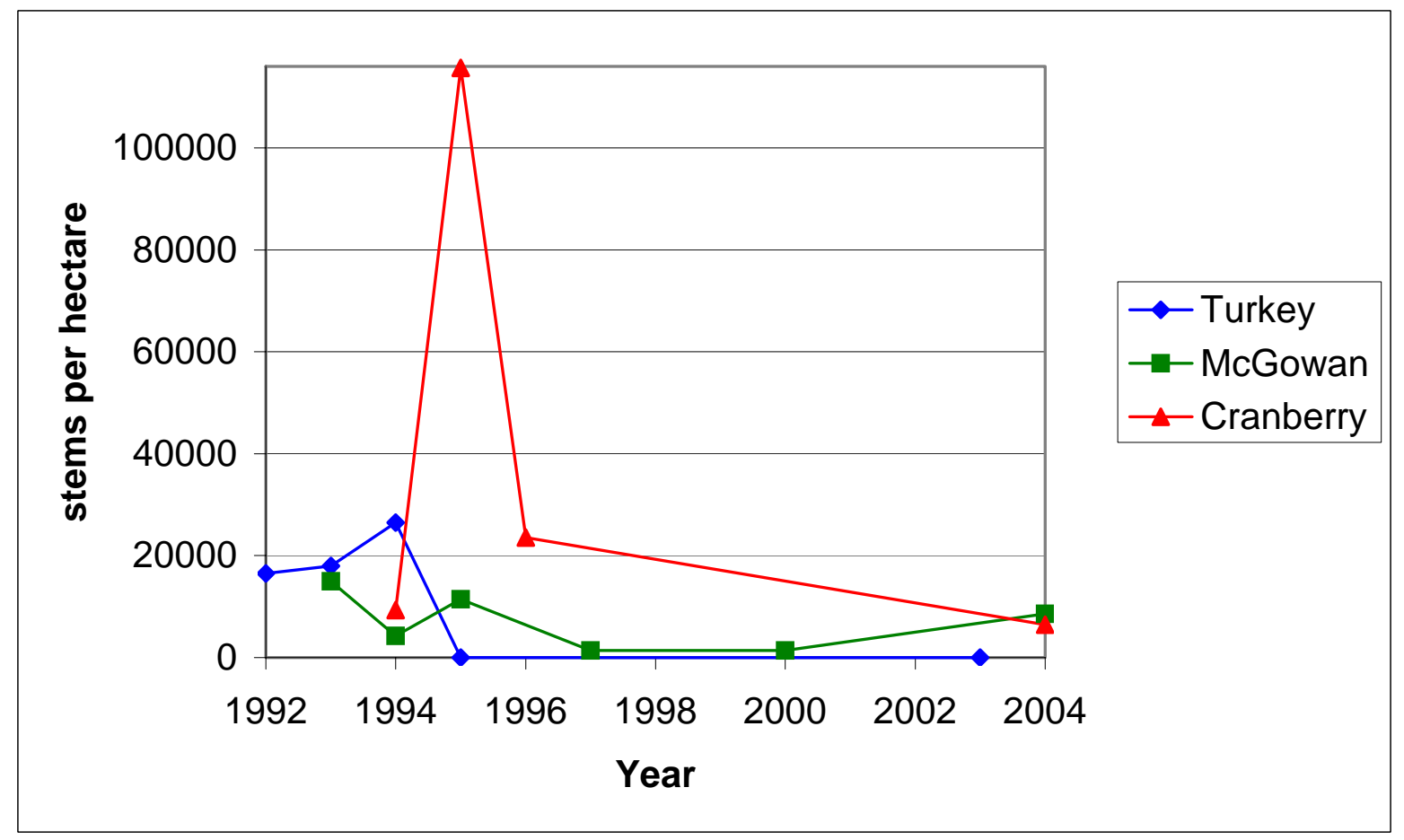

Figure 25. The temporal pattern of hardwood seedling densities for all size classes and forest zones combined. 


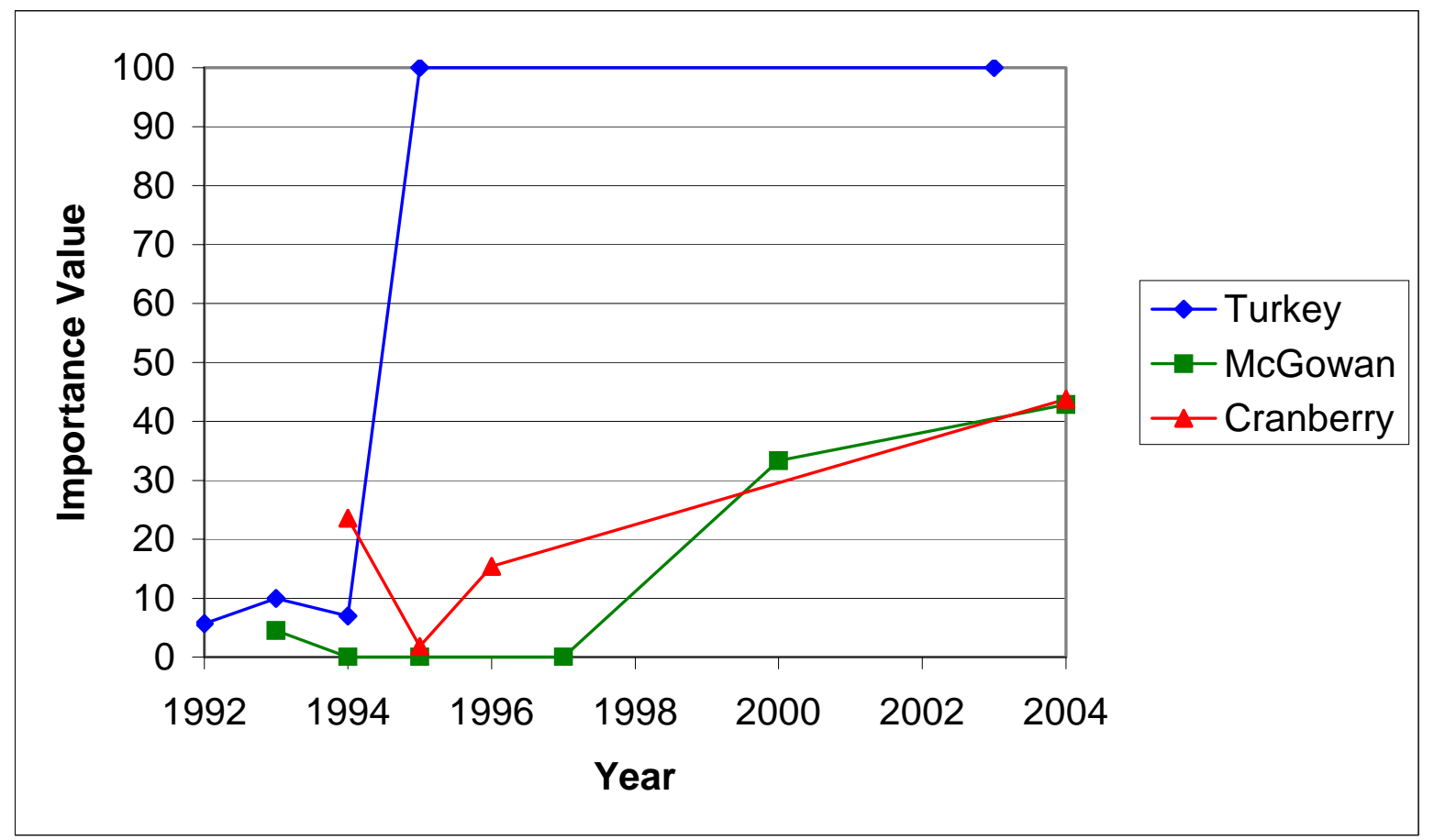

Figure 26. The temporal pattern of importance values for red spruce seedlings for all size classes and forest zones combined.

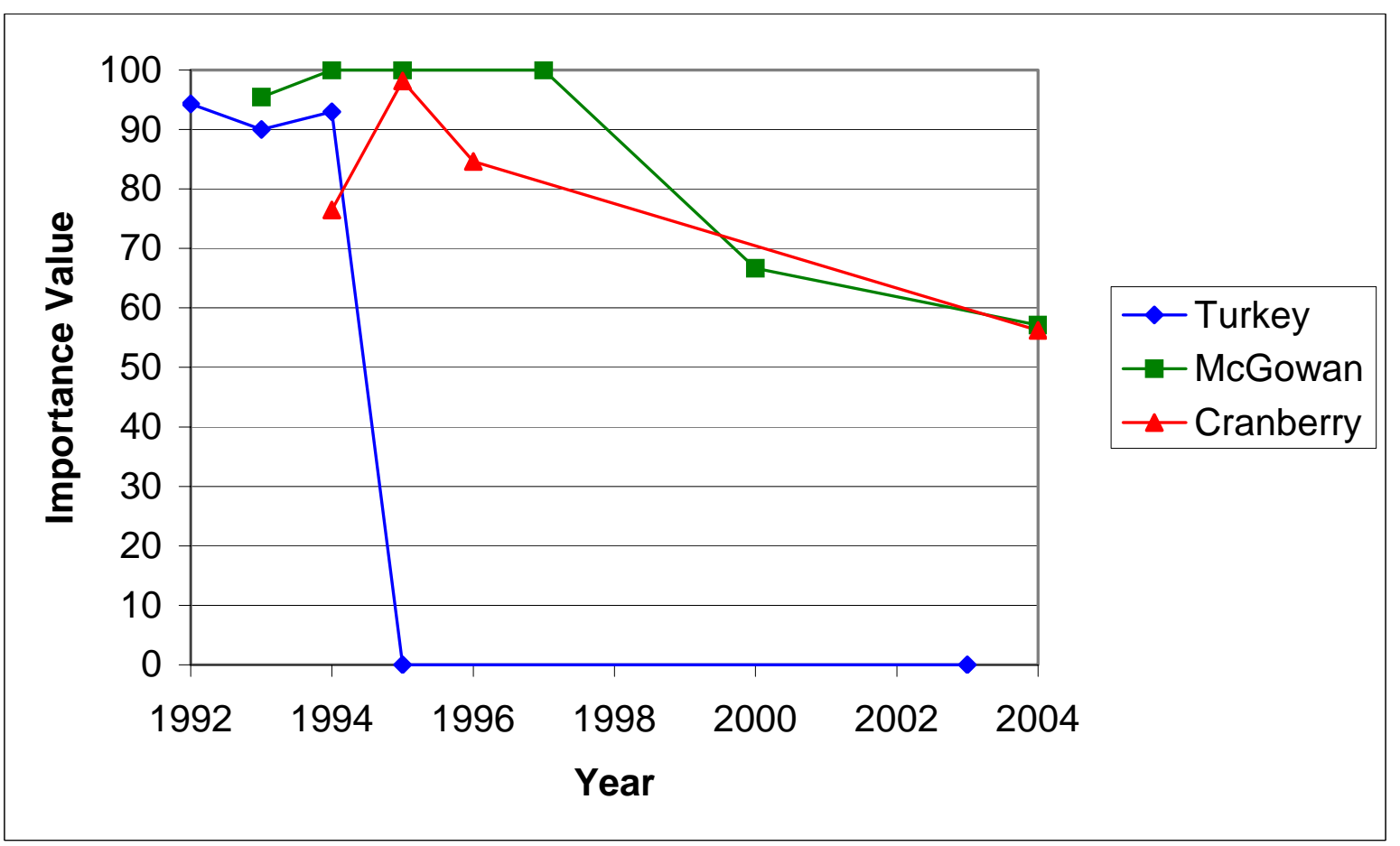

Figure 27. The temporal pattern of importance values for hardwood seedlings for all size classes and forest zones combined. 


\section{Trends by Forest Zone.}

\section{Present condition of forest zones}

All variables for the red spruce component of the tree stratum revealed significant differences between the zones (Table 12a). Red spruce values were lowest for each variable in the hardwood zone, and were highest in the red spruce zone. Red spruce trees per hectare were significantly greater for the red spruce zone compared to the hardwood zone $(\mathrm{P}=0.0131)$. The ecotone was not significantly separated from the red spruce zone with respect to red spruce trees per hectare.

Red spruce basal area per hectare showed significant differences between the ecotone and red spruce zones $(\mathrm{P}=0.0002)$, and the hardwood and red spruce zones $(\mathrm{P}<0.0001)$. The relative density of red spruce trees revealed significant differences between the ecotone and red spruce zones $(\mathrm{P}=0.0031)$, and the hardwood and red spruce covertypes $(\mathrm{P}=0.0002)$. The relative basal area of red spruce showed significant differences between the ecotone and red spruce zones $(\mathrm{P}=0.0013)$, and the hardwood and red spruce zones $(\mathrm{P}=0.0001)$. The importance value of red spruce was significantly different between all three zones, the ecotone and hardwood zones $(\mathrm{P}=0.0065)$, the ecotone and red spruce zones $(\mathrm{P}=0.0011)$, and the hardwood and ecotone zones $(\mathrm{P}<0.0001)$. The variables for hardwood tree species were lowest in the red spruce zone and the highest in the hardwood zone (Table. 12b). 
Table 12a. Red spruce tree stratum variable means for the ANOVA by forest zone. Means with different letters indicate statistical significance.

\begin{tabular}{|c|c|c|c|c|c|c|c|c|}
\hline \multicolumn{9}{|c|}{ SITE } \\
\hline Zone & \multicolumn{2}{|c|}{ Cranberry } & \multicolumn{2}{|c|}{ McGowan } & \multicolumn{2}{|c|}{ Turkey } & \multicolumn{2}{|c|}{ All Sites } \\
\hline \multicolumn{9}{|c|}{ Basal area $\mathrm{m}^{2} / \mathrm{ha}$} \\
\hline RS & 34.5 & $\mathrm{a}$ & 36.8 & $\mathrm{a}$ & 11.3 & & 25.2 & a \\
\hline Eco & 6.8 & $\mathrm{~b}$ & 15.2 & $b$ & 4.3 & & 8.3 & $b$ \\
\hline HW & 0.5 & $b$ & 1.8 & $b$ & 1.3 & & 1.2 & $b$ \\
\hline \multicolumn{9}{|c|}{ Trees / hectare } \\
\hline RS & 1000 & & 1250 & & 2567 & $\mathrm{a}$ & 1743 & a \\
\hline Eco & 1067 & & 1833 & & 1000 & $\mathrm{~b}$ & 1270 & a \\
\hline HW & 150 & & 950 & & 467 & $\mathrm{~b}$ & 514 & $b$ \\
\hline \multicolumn{9}{|c|}{ Relative Density } \\
\hline RS & 58 & $a$ & 50 & & 80 & $\mathrm{a}$ & 65 & $a$ \\
\hline Eco & 45 & $\mathrm{a}$ & 66 & & 40 & $\mathrm{~b}$ & 49 & $b$ \\
\hline HW & 9 & $\mathrm{~b}$ & 53 & & 19 & b & 25 & $c$ \\
\hline \multicolumn{9}{|c|}{ Relative Basal Area } \\
\hline RS & 75 & $a$ & 61 & a & 37 & $\mathrm{a}$ & 55 & $a$ \\
\hline Eco & 14 & $\mathrm{~b}$ & 32 & $a b$ & 12 & $a b$ & 18 & $b$ \\
\hline HW & 1 & $b$ & 7 & b & 1 & b & 3 & $b$ \\
\hline \multicolumn{9}{|c|}{ Importance Value } \\
\hline RS & 66 & $\mathrm{a}$ & 55 & & 59 & $\mathrm{a}$ & 60 & $a$ \\
\hline Eco & 29 & $\mathrm{~b}$ & 49 & & 26 & $b$ & 34 & $b$ \\
\hline HW & 5 & $\mathrm{C}$ & 30 & & 10 & $\mathrm{~b}$ & 14 & $c$ \\
\hline
\end{tabular}


Table 12b. Hardwood species tree stratum variable means for the ANOVA by forest zone. Means with different letters indicate statistical significance.

\begin{tabular}{|c|c|c|c|c|c|c|c|c|}
\hline \multicolumn{9}{|c|}{ SITE } \\
\hline Zone & \multicolumn{2}{|c|}{ Cranberry } & \multicolumn{2}{|c|}{ McGowan } & \multicolumn{2}{|c|}{ Turkey } & \multicolumn{2}{|c|}{ All Sites } \\
\hline \multicolumn{9}{|c|}{ Basal area $\mathrm{m}^{2} / \mathrm{ha}$} \\
\hline RS & 12.3 & & 23.5 & & 25.1 & & 21.0 & \\
\hline Eco & 37.9 & & 31.8 & & 33.7 & & 34.4 & \\
\hline HW & 37.4 & & 24.4 & & 54.8 & & 41.2 & \\
\hline \multicolumn{9}{|c|}{ Trees / hectare } \\
\hline RS & 750 & & 1150 & & 667 & $\mathrm{a}$ & 829 & \\
\hline Eco & 1167 & & 667 & & 1325 & $\mathrm{~b}$ & 1080 & \\
\hline $\mathrm{HW}$ & 1050 & & 800 & & 1433 & $\mathrm{~b}$ & 1143 & \\
\hline \multicolumn{9}{|c|}{ Relative Density } \\
\hline RS & 42 & $\mathrm{a}$ & 50 & & 20 & $\mathrm{a}$ & 7 & $a$ \\
\hline Eco & 55 & $\mathrm{a}$ & 34 & & 60 & $\mathrm{~b}$ & 51 & $b$ \\
\hline HW & 91 & $b$ & 47 & & 81 & $\mathrm{~b}$ & 75 & c \\
\hline \multicolumn{9}{|c|}{ Relative Basal Area } \\
\hline RS & 25 & $\mathrm{a}$ & 39 & $\mathrm{a}$ & 63 & $a$ & 45 & a \\
\hline Eco & 86 & $b$ & 68 & $a b$ & 88 & $a b$ & 82 & $b$ \\
\hline HW & 99 & $b$ & 93 & $\mathrm{~b}$ & 99 & $\mathrm{~b}$ & 97 & $b$ \\
\hline \multicolumn{9}{|c|}{ Importance Value } \\
\hline RS & 34 & $a$ & 45 & & 41 & $a$ & 40 & $a$ \\
\hline Eco & 71 & $b$ & 51 & & 74 & $b$ & 66 & $b$ \\
\hline HW & 95 & c & 70 & & 90 & b & 86 & C \\
\hline
\end{tabular}


The sapling stratum variables of density (stems/ha) and importance value for both red spruce and hardwood stems varied by forest zone (Table. 13). The density of red spruce saplings ranged from 1830 stems per hectare in the ecotone to 957 stems per hectare in the hardwood zone, however this difference was not significant. The calculated importance value for red spruce was highest in the ecotone and lowest in the red spruce covertype. The ecotone had a significantly higher red spruce importance value than the red spruce zone $(\mathrm{P}=0.0338)$. The density of hardwood saplings was generally highest in the hardwood covertype (714 stems per hectare), and lowest in the ecotone (430 stems per hectare), however no statistical significance was detected.

Table 13. Sapling variables for ANOVA by forest zone (all sites combined) showing mean values. Means with different letters indicate statistical significance..

\begin{tabular}{|c|c|c|c|c|c|c|}
\hline \multicolumn{7}{|c|}{ SITE } \\
\hline \multirow[t]{2}{*}{ Zone } & \multirow[t]{2}{*}{ Cranberry } & \multicolumn{2}{|c|}{ McGowan } & \multirow[t]{2}{*}{ Turkey } & \multicolumn{2}{|c|}{ All Sites } \\
\hline & & uce ste & sl & & & \\
\hline RS & 1900 & 0 & & 1600 & 1229 & \\
\hline Eco & 2033 & 1400 & & 2000 & 1830 & \\
\hline \multirow[t]{2}{*}{ HW } & 1250 & 1200 & & 600 & 957 & \\
\hline & \multicolumn{4}{|c|}{ Red spruce Importance Value } & & \\
\hline RS & 96 & 0 & $\mathrm{a}$ & 59 & 53 & a \\
\hline Eco & 72 & 83 & $\mathrm{~b}$ & 84 & 80 & $b$ \\
\hline \multirow[t]{2}{*}{ HW } & 49 & 100 & $\mathrm{~b}$ & 46 & 62 & $a b$ \\
\hline & \multicolumn{4}{|c|}{ Hardwoods stems / hectare } & & \\
\hline RS & 50 & 0 & & 1233 & 543 & \\
\hline Eco & 900 & 33 & & 375 & 430 & \\
\hline \multirow[t]{2}{*}{ HW } & 1250 & 0 & & 833 & 714 & \\
\hline & \multicolumn{4}{|c|}{ Hardwoods Importance Value } & & \\
\hline RS & 4 & 100 & $a$ & 41 & 47 & $a$ \\
\hline Eco & 28 & 17 & $\mathrm{~b}$ & 16 & 20 & $b$ \\
\hline HW & 51 & 0 & $\mathrm{~b}$ & 54 & 38 & $a b$ \\
\hline
\end{tabular}


Red spruce seedlings had the highest density in the ecotone (Table. 14) although this difference was not statistically significant. Red spruce seedling importance value was significantly greater in the ecotone compared to the red spruce forest zone $(P=0.0235)$.

Table 14. Seedling variable means (all size classes combined) for the ANOVA by forest zone. Means with different letters indicate statistical significance.

\begin{tabular}{|c|c|c|c|c|c|c|}
\hline \multicolumn{7}{|c|}{ SITE } \\
\hline Zone & Cranbe & & McGowan & Turkey & \multicolumn{2}{|c|}{ All Sites } \\
\hline \multicolumn{7}{|c|}{ Red spruce stems / hectare } \\
\hline RS & 10000 & & 7500 & 0 & 500 & \\
\hline Eco & 5000 & & 8333 & 7500 & 7000 & \\
\hline HW & 0 & & 2500 & 0 & 714 & \\
\hline \multicolumn{7}{|c|}{ Red spruce Importance Value } \\
\hline RS & 100 & $\mathrm{a}$ & 50 & 0 & 43 & a \\
\hline Eco & 83 & a & 21 & 50 & 51 & a \\
\hline HW & 0 & $b$ & 17 & 0 & 5 & $b$ \\
\hline \multicolumn{7}{|c|}{ Hardwoods stems / hectare } \\
\hline RS & 0 & a & 5000 & 0 & 1429 & \\
\hline Eco & 1667 & a & 10000 & 0 & 3500 & \\
\hline HW & 20000 & $b$ & 10000 & 0 & 8571 & \\
\hline \multicolumn{7}{|c|}{ Hardwoods Importance Value } \\
\hline RS & 0 & & 0 & 0 & 14 & \\
\hline Eco & 17 & & 79 & 0 & 29 & \\
\hline HW & 50 & & 50 & 0 & 38 & \\
\hline
\end{tabular}




\section{Temporal Patterns: Red Spruce Zone}

Tables 15a and 15b report the change in the mean value between the first and last surveys for the variables of basal area, trees per hectare, relative density, relative basal area, and importance value for red spruce and hardwood species in the tree stratum. The change for these variables with respect to time was not found to be significant in the red spruce zone except for red spruce trees per hectare at Turkey Run $(\mathrm{P}=0.0022)$. Although not significant, red spruce density, relative density, relative basal area and importance values all exhibited an increasing trend with time for all sites combined. Conversely, the density, relative density, relative basal area, and importance value for hardwood species all experienced a decreasing trend (not significant) over time.

Table 15a. Red spruce tree stratum variable means for the ANOVA for the red spruce zone, first survey to last survey. Means with different letters indicate statistical significance.

\begin{tabular}{|c|c|c|c|c|c|}
\hline \multicolumn{6}{|c|}{ SITE } \\
\hline Time & Cranberry & McGowan & Turke & & All Sites \\
\hline \multicolumn{6}{|c|}{ Basal area $\mathrm{m}^{2} / \mathrm{ha}$} \\
\hline First & 46.5 & 33.7 & 5.3 & & 25.2 \\
\hline Last & 34.5 & 36.8 & 11.3 & & 25.3 \\
\hline \multicolumn{6}{|c|}{ Trees / hectare } \\
\hline First & 700 & 1550 & 1167 & a & 1143 \\
\hline Last & 1000 & 1250 & 2567 & $\mathrm{~b}$ & 1743 \\
\hline \multicolumn{6}{|c|}{ Relative Density } \\
\hline First & 53 & 55 & 60 & & 56 \\
\hline Last & 58 & 50 & 80 & & 65 \\
\hline \multicolumn{6}{|c|}{ Relative Basal Area } \\
\hline First & 82 & 64 & 13 & & 47 \\
\hline Last & 75 & 60 & 37 & & 55 \\
\hline \multicolumn{6}{|c|}{ Importance Value } \\
\hline First & 67 & 60 & 36 & & 52 \\
\hline Last & 66 & 55 & 59 & & 60 \\
\hline
\end{tabular}


Table 15b. Hardwood species tree stratum variable means for the ANOVA for the red spruce zone, first survey to last survey. Means with different letters indicate statistical significance.

\begin{tabular}{|c|c|c|c|c|}
\hline \multicolumn{5}{|c|}{ SITE } \\
\hline Time & Cranberry & McGowan & Turkey & All Sites \\
\hline \multicolumn{5}{|c|}{ Basal area $\mathrm{m}^{2} / \mathrm{ha}$} \\
\hline First & 8.9 & 18.5 & 26.3 & 19.1 \\
\hline Last & 12.3 & 23.5 & 25.1 & 21.0 \\
\hline \multicolumn{5}{|c|}{ Trees I hectare } \\
\hline First & 650 & 1300 & 767 & 886 \\
\hline Last & 750 & 1150 & 667 & 828 \\
\hline \multicolumn{5}{|c|}{ Relative Density } \\
\hline First & 48 & 45 & 40 & 44 \\
\hline Last & 42 & 50 & 20 & 35 \\
\hline \multicolumn{5}{|c|}{ Relative Basal Area } \\
\hline First & 18 & 36 & 87 & 53 \\
\hline Last & 25 & 39 & 63 & 45 \\
\hline \multicolumn{5}{|c|}{ Importance Value } \\
\hline First & 33 & 40 & 64 & 48 \\
\hline Last & 34 & 44 & 41 & 40 \\
\hline
\end{tabular}

The density of red spruce saplings (all sites combined) experienced a non-significant decrease of 643 stems per hectare, while the importance value dropped from 65 to 53 between the first and last measurement period (Table. 16). By contrast, hardwood species experienced an overall increase of 314 stems per hectare, while the importance value rose from 21 to 48 . These increases were not statistically significant. The rise in hardwood sapling importance value at the McGowan Mountain site was found to be statistically significant $(P=0.0375)$. In addition, the density of hardwood saplings at the Turkey Run site increased significantly $(\mathrm{P}=0.0386)$ by 1066 stems per hectare.

Red spruce seedlings showed a general trend of increasing density with respect to time (Table. 17). Likewise, the importance value of red spruce seedlings increased, although the increases were not statistically significant. Conversely, the density and importance value for hardwood seedlings showed a non-significant decrease over time. The decrease of hardwood 
seedling importance value at the Turkey Run site was statistically significant $(\mathrm{P}=0.0045)$.

When seedling data were further broken down by the four size classes, for both red spruce and hardwood species, no significant differences with respect to time were detected.

Table 16. Sapling variable means for the ANOVA for the red spruce zone, first survey to last survey. Means with different letters indicate statistical significance.

\begin{tabular}{|c|c|c|c|c|c|c|}
\hline \multicolumn{7}{|c|}{ SITE } \\
\hline Time & Cranberry & McGov & Ian & Turke & & All Sites \\
\hline \multicolumn{7}{|c|}{ Red Spruce Stems / hectare } \\
\hline First & 2300 & 0 & & 2833 & & 1871 \\
\hline Last & 1900 & 0 & & 1600 & & 1228 \\
\hline \multicolumn{7}{|c|}{ Red Spruce Importance Value } \\
\hline First & 86 & 0 & & 95 & & 65 \\
\hline Last & 96 & 0 & & 59 & & 53 \\
\hline \multicolumn{7}{|c|}{ Hardwoods Stems / hectare } \\
\hline First & 500 & 50 & & 167 & a & 229 \\
\hline Last & 50 & 0 & & 1233 & $\mathrm{~b}$ & 543 \\
\hline \multicolumn{7}{|c|}{ Hardwoods Importance Value } \\
\hline First & 14 & 50 & $\mathrm{a}$ & 5 & & 21 \\
\hline Last & 4 & 100 & $\mathrm{~b}$ & 41 & & 48 \\
\hline
\end{tabular}


Table 17. Seedling variable means (size classes pooled) for the ANOVA for the red spruce zone, first survey to last survey. Means with different letters indicate statistical significance.

\begin{tabular}{|c|c|c|c|c|c|}
\hline \multicolumn{6}{|c|}{ SITE } \\
\hline Time & Cranberry & McGowan & Turkey & & All Sites \\
\hline \multicolumn{6}{|c|}{ Red Spruce Stems / hectare } \\
\hline First & 7500 & 0 & 0 & & 2143 \\
\hline Last & 10000 & 7500 & 0 & & 5000 \\
\hline \multicolumn{6}{|c|}{ Red Spruce Importance Value } \\
\hline First & 50 & 0 & 0 & & 14 \\
\hline Last & 100 & 50 & 0 & & 43 \\
\hline \multicolumn{6}{|c|}{ Hardwoods Stems / hectare } \\
\hline First & 0 & 0 & 20000 & & 8571 \\
\hline Last & 0 & 5000 & 0 & & 1429 \\
\hline \multicolumn{6}{|c|}{ Hardwoods Importance Value } \\
\hline First & 0 & 0 & 100 & $\mathrm{a}$ & 43 \\
\hline Last & 0 & 50 & 0 & $\mathrm{~b}$ & 14 \\
\hline
\end{tabular}




\section{Temporal Patterns: Ecotone Zone}

All variables tested for red spruce experienced an increase with respect to time in the ecotone zone (Table. 18a). The density of red spruce trees experienced a statistically significant increase of 590 trees per hectare $(\mathrm{P}=0.0294)$. The relative density of red spruce increased from 32 to 49 which also proved to be significant at the $\alpha=0.05$ level $(P=0.0186)$. The increase in red spruce density $(\mathrm{P}=0.0041)$ and relative density $(\mathrm{P}=0.0126)$ at the McGowan Mountain site were found to be statistically significant. The hardwood species in the ecotone showed decreasing values for all variables tested with respect to time (Table. 18b). The relative density of hardwoods decreased from 68 to 51, which proved to be statistically significant $(\mathrm{P}=0.0186)$, and the relative density of hardwoods at the McGowan Mountain site decreased significantly (P $=0.0126$ ) from 65 to 34 .

Table 18a. Red spruce tree stratum variable means for the ANOVA for the ecotone zone, first survey to last survey. Means with different letters indicate statistical significance.

\begin{tabular}{|c|c|c|c|c|c|c|}
\hline \multicolumn{7}{|c|}{ SITE } \\
\hline Time & Cranberry & McGov & & Turkey & \multicolumn{2}{|c|}{ All Sites } \\
\hline \multicolumn{7}{|c|}{ Basal area $\mathrm{m}^{2} / \mathrm{ha}$} \\
\hline First & 5.0 & 13.1 & & 1.8 & 6.1 & \\
\hline Last & 6.8 & 15.2 & & 4.3 & 8.3 & \\
\hline \multicolumn{7}{|c|}{ Trees / hectare } \\
\hline First & 833 & 533 & a & 675 & 680 & a \\
\hline Last & 1067 & 1833 & b & 1000 & 1270 & $b$ \\
\hline \multicolumn{7}{|c|}{ Relative Density } \\
\hline First & 36 & 35 & a & 25 & 32 & $a$ \\
\hline Last & 45 & 66 & $b$ & 40 & 49 & $b$ \\
\hline \multicolumn{7}{|c|}{ Relative Basal Area } \\
\hline First & 11 & 29 & & 5 & 14 & \\
\hline Last & 14 & 32 & & 12 & 18 & \\
\hline \multicolumn{7}{|c|}{ Importance Value } \\
\hline First & 24 & 32 & & 15 & 23 & \\
\hline Last & 29 & 49 & & 26 & 34 & \\
\hline
\end{tabular}


Table 18b. Hardwood species tree stratum variable means for the ANOVA for the ecotone zone, first survey to last survey. Means with different letters indicate statistical significance.

\begin{tabular}{|c|c|c|c|c|c|}
\hline \multicolumn{6}{|c|}{ SITE } \\
\hline Time & Cranberry & McGowan & Turkey & \multicolumn{2}{|l|}{ All Sites } \\
\hline \multicolumn{6}{|c|}{ Basal area $\mathrm{m}^{2} / \mathrm{ha}$} \\
\hline First & 34.1 & 31.6 & 37.8 & 34.8 & \\
\hline Last & 37.9 & 31.8 & 33.7 & 34.4 & \\
\hline \multicolumn{6}{|c|}{ Trees / hectare } \\
\hline First & 1200 & 800 & 1500 & 1200 & \\
\hline Last & 1167 & 667 & 1325 & 1080 & \\
\hline \multicolumn{6}{|c|}{ Relative Density } \\
\hline First & 64 & 65 & 75 & 68 & a \\
\hline Last & 55 & 34 & 60 & 51 & $b$ \\
\hline \multicolumn{6}{|c|}{ Relative Basal Area } \\
\hline First & 89 & 71 & 95 & 86 & \\
\hline Last & 86 & 68 & 88 & 82 & \\
\hline \multicolumn{6}{|c|}{ Importance Value } \\
\hline First & 89 & 68 & 85 & 77 & \\
\hline Last & 86 & 51 & 74 & 66 & \\
\hline
\end{tabular}

The density of red spruce saplings in the ecotone zone remained fairly constant over time (Table. 19). The density and the importance value of hardwood species in the ecotone zone decreased with time, although none of the differences were found to be statistically significant. The density and importance value for red spruce in the seedling stratum in the ecotone zone (all sites pooled) experienced a general increase (Table. 20). The increased density of red spruce from 1500 to 7000 stems per hectare was found to be statistically significant $(P=0.0325)$. The Cranberry study site experienced a significant $(\mathrm{P}=0.0085)$ increase in the importance value of red spruce. In contrast, the density and importance value for hardwood seedlings (all sites pooled) decreased with respect to time. These trends however were not statistically significant. The ecotone at Turkey Run saw a significant $(\mathrm{P}=0.0248)$ decrease in the importance value of hardwood seedlings from 67 to 0 . As was the case in the red spruce zone, analysis of seedlings by size class failed to reveal any significant differences with respect to time in the ecotone zone. 
Table 19. Sapling variable means for the ANOVA for the ecotone zone, first survey to last survey. Means with different letters indicate statistical significance.

\begin{tabular}{|c|c|c|c|c|}
\hline \multicolumn{5}{|c|}{ SITE } \\
\hline Time & Cranberry & McGowan & Turkey & All Sites \\
\hline \multicolumn{5}{|c|}{ Red Spruce Stems / hectare } \\
\hline First & 1900 & 1700 & 1900 & 1840 \\
\hline Last & 2033 & 1400 & 2000 & 1830 \\
\hline \multicolumn{5}{|c|}{ Red Spruce Importance Value } \\
\hline First & 67 & 64 & 69 & 67 \\
\hline Last & 72 & 83 & 84 & 80 \\
\hline \multicolumn{5}{|c|}{ Hardwoods Stems / hectare } \\
\hline First & 1133 & 67 & 975 & 750 \\
\hline Last & 900 & 33 & 375 & 430 \\
\hline \multicolumn{5}{|c|}{ Hardwoods Importance Value } \\
\hline First & 33 & 3 & 15 & 18 \\
\hline Last & 28 & 17 & 4 & 16 \\
\hline
\end{tabular}

Table 20. Seedling variable means (size classes pooled) for the ANOVA for the ecotone zone, first survey to last survey. Means with different letters indicate statistical significance.

\begin{tabular}{|c|c|c|c|c|c|c|c|}
\hline \multicolumn{8}{|c|}{ SITE } \\
\hline \multirow[t]{2}{*}{ Time } & \multicolumn{2}{|c|}{ Cranberry } & McGowan & \multicolumn{2}{|c|}{ Turkey } & \multicolumn{2}{|c|}{ All Sites } \\
\hline & \multicolumn{5}{|c|}{ Red Spruce Stems / hectare } & & \\
\hline First & 0 & & 1667 & 2500 & & 1500 & a \\
\hline \multirow{2}{*}{ Last } & 5000 & & 8333 & 7500 & & 7000 & $b$ \\
\hline & \multicolumn{5}{|c|}{ Red Spruce Importance Value } & & \\
\hline First & 0 & a & 33 & 33 & & 23 & \\
\hline \multirow[t]{2}{*}{ Last } & 83 & $\mathrm{~b}$ & 21 & 50 & & 51 & \\
\hline & \multicolumn{5}{|c|}{ Hardwoods Stems / hectare } & & \\
\hline First & 11667 & & 15000 & 7500 & & 11000 & \\
\hline \multirow[t]{2}{*}{ Last } & 1667 & & 10000 & 0 & & 3500 & \\
\hline & \multicolumn{5}{|c|}{ Hardwoods Importance Value } & & \\
\hline First & 67 & & 67 & 67 & $\mathrm{a}$ & 67 & \\
\hline Last & 17 & & 79 & 0 & $b$ & 29 & \\
\hline
\end{tabular}


Temporal Patterns: Hardwood Zone

Red spruce in the tree stratum of the hardwoods zone (all sites pooled) experienced an increase over time for all the variables considered (Table. 21a). The density of red spruce trees increased by 428 stems per hectare, however this change was not statistically significant. However, the increase in the relative density of red spruce from 5 to 25 was found significant (P $=0.0225$ ) at the $\alpha=0.05$ level. The relative density of red spruce at the McGowan Mountain site increased from 5 to 53, which was also found to be significant $(\mathrm{P}=0.0022)$.

Basal area was the only variable that increased for hardwood species in the hardwood zone (all sites pooled) (Table. 21b). The density, relative basal area, and importance value of hardwood species all decreased with respect to time within the hardwood zone, although these decreases were not statistically significant. However, the relative basal area of hardwood species decreased significantly $(\mathrm{P}=0.0225$ ) from 95 to 74 . The decrease in the relative density of hardwood species at the McGowan Mountain site also proved to be statistically significant $(\mathrm{P}=$ 0.0022). 
Table 21a. Red spruce tree stratum variable means for the ANOVA for the hardwood zone, first survey to last survey. Means with different letters indicate statistical significance.

\begin{tabular}{|c|c|c|c|c|c|}
\hline \multicolumn{6}{|c|}{ SITE } \\
\hline Time & Cranberry & McGowan & Turkey & All $\mathrm{S}$ & \\
\hline \multicolumn{6}{|c|}{ Basal area $\mathrm{m}^{2} / \mathrm{ha}$} \\
\hline First & 0.2 & 0.3 & 0.3 & 0.3 & \\
\hline Last & 0.5 & 1.8 & 1.3 & 1.2 & \\
\hline \multicolumn{6}{|c|}{ Trees I hectare } \\
\hline First & 100 & 50 & 100 & 86 & \\
\hline Last & 150 & 950 & 467 & 514 & \\
\hline \multicolumn{6}{|c|}{ Relative Density } \\
\hline First & 6 & $5 \quad a$ & 4 & 5 & $a$ \\
\hline Last & 9 & 53 & 19 & 25 & $b$ \\
\hline \multicolumn{6}{|c|}{ Relative Basal Area } \\
\hline First & 1 & 1 & 0 & 1 & \\
\hline Last & 1 & 7 & 1 & 3 & \\
\hline \multicolumn{6}{|c|}{ Importance Value } \\
\hline First & 3 & 3 & 2 & 3 & \\
\hline Last & 5 & 30 & 10 & 14 & \\
\hline
\end{tabular}


Table 21b. Hardwood tree stratum variable means for the ANOVA for the hardwood zone, first survey to last survey. Means with different letters indicate statistical significance.

\begin{tabular}{|c|c|c|c|c|c|}
\hline \multicolumn{6}{|c|}{ SITE } \\
\hline Time & Cranberry & McGowan & Turkey & \multicolumn{2}{|l|}{ All Sites } \\
\hline \multicolumn{6}{|c|}{ Basal area $\mathrm{m}^{2} / \mathrm{ha}$} \\
\hline First & 26.9 & 27.7 & 55.7 & 39.5 & \\
\hline Last & 37.4 & 24.4 & 54.8 & 41.2 & \\
\hline \multicolumn{6}{|c|}{ Trees / hectare } \\
\hline First & 1000 & 1000 & 1567 & 1243 & \\
\hline Last & 1050 & 800 & 1433 & 1143 & \\
\hline \multicolumn{6}{|c|}{ Relative Density } \\
\hline First & 94 & 95 & 96 & 95 & a \\
\hline Last & 91 & 47 & 81 & 74 & $b$ \\
\hline \multicolumn{6}{|c|}{ Relative Basal Area } \\
\hline First & 99 & 99 & 100 & 99 & \\
\hline Last & 99 & 93 & 99 & 97 & \\
\hline \multicolumn{6}{|c|}{ Importance Value } \\
\hline First & 97 & 97 & 98 & 97 & \\
\hline Last & 95 & 70 & 90 & 86 & \\
\hline
\end{tabular}

The density of red spruce saplings in the hardwood zone (all sites pooled) remained static (Table. 22). However the importance value for red spruce in the sapling stratum increased, although not significantly. The density of hardwood species showed a general decreasing trend with respect to time and the importance value for hardwoods also declined. Neither of these were found to be statistically significant. The changes over time for red spruce and hardwood saplings did not show any significant changes within individual study sites.

The total density of red spruce seedlings (all sites pooled) remained static in the hardwood zone with respect to time (Table. 23). The density of hardwood seedlings decreased significantly ( $\mathrm{P}=$ $0.0340)$ by 15000 stems per hectare. The density $(\mathrm{P}=0.0264)$ and importance value $(\mathrm{P}=$ 0.0495) of hardwood seedlings at the Turkey Run site experienced significant reductions with respect to time. 
Table 22. Sapling variable means for the ANOVA for the hardwood zone, first survey to last survey. Means with different letters indicate statistical significance.

\begin{tabular}{|c|c|c|c|c|}
\hline \multicolumn{5}{|c|}{ SITE } \\
\hline Time & Cranberry & McGowan & Turkey & All Sites \\
\hline \multicolumn{5}{|c|}{ Red Spruce Stems / hectare } \\
\hline First & 550 & 1800 & 667 & 957 \\
\hline Last & 1250 & 1200 & 600 & 957 \\
\hline \multicolumn{5}{|c|}{ Red Spruce Importance Value } \\
\hline First & 23 & 98 & 43 & 53 \\
\hline Last & 49 & 100 & 46 & 62 \\
\hline \multicolumn{5}{|c|}{ Hardwoods Stems / hectare } \\
\hline First & 1800 & 50 & 833 & 886 \\
\hline Last & 1250 & 0 & 833 & 714 \\
\hline \multicolumn{5}{|c|}{ Hardwoods Importance Value } \\
\hline First & 77 & 2 & 57 & 47 \\
\hline Last & 51 & 0 & 54 & 38 \\
\hline
\end{tabular}

Table 23. Seedling variable means (size classes pooled) for the ANOVA for the hardwood zone, first survey to last survey. Means with different letters indicate statistical significance.

\begin{tabular}{|c|c|c|c|c|c|c|}
\hline \multicolumn{7}{|c|}{ SITE } \\
\hline Time & Cranberry & McGowan & Turke & & All Site & \\
\hline \multicolumn{6}{|c|}{ Red Spruce Stems / hectare } & \\
\hline First & 2500 & 0 & 0 & & 714 & \\
\hline Last & 0 & 2500 & 0 & & 714 & \\
\hline \multicolumn{7}{|c|}{ Red Spruce Importance Value } \\
\hline First & 25 & 0 & 0 & & 7 & \\
\hline Last & 0 & 17 & 0 & & 5 & \\
\hline \multicolumn{7}{|c|}{ Hardwoods Stems / hectare } \\
\hline First & 15000 & 30000 & 25000 & a & 23571 & a \\
\hline Last & 20000 & 10000 & 0 & $\mathrm{~b}$ & 8571 & $b$ \\
\hline \multicolumn{7}{|c|}{ Hardwoods Importance Value } \\
\hline First & 75 & 50 & 67 & $\mathrm{a}$ & 64 & \\
\hline Last & 50 & 83 & 0 & b & 38 & \\
\hline
\end{tabular}


Eighteen types of ground cover were encountered between the three sites. The percent cover for bryophytes, Dryopteris spp., and coarse woody debris were the only ground covertypes found to be significantly correlated with the density of red spruce seedlings. The trend of increasing densities of red spruce seedlings with increasing percent of ground cover for bryophytes and coarse woody debris was found. Decreasing densities of red spruce seedlings were found with respect to an increase of percent cover for Dryopteris spp.
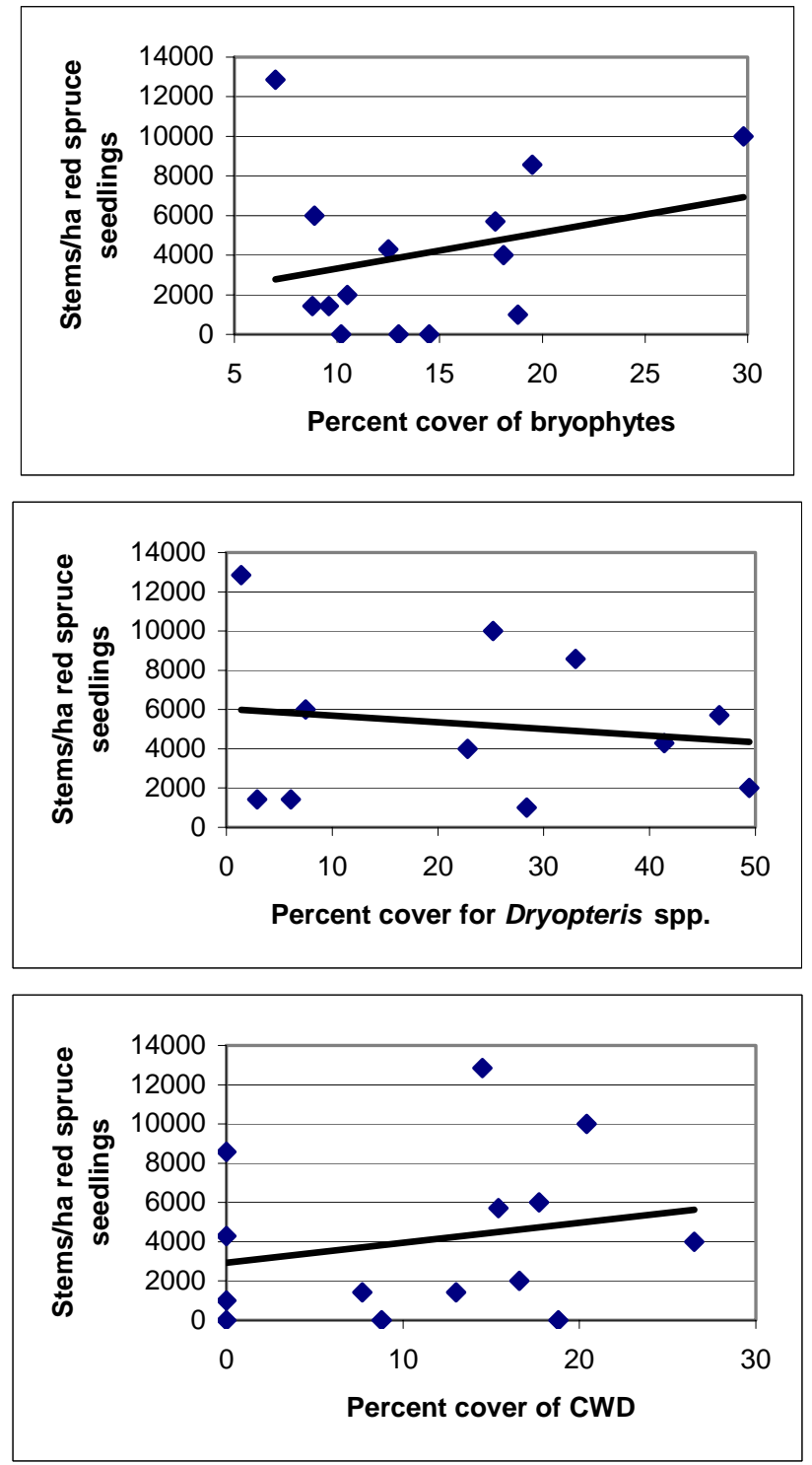

Figure 28. Relationship of percent ground cover to red spruce seedling density. 


\section{Chapter 6. Discussion}

\section{$\underline{\text { Current Site Conditions }}$}

Turkey Run, McGowan Mountain, and the Cranberry site represent three distinct ecological situations: 1. a disturbed spruce stand thirteen years following the disturbance event; 2. a second-growth stand approximately 70 years after a major disturbance event; and 3. a mature stand which appears to have experienced an insignificant amount of disturbance. The Turkey Run stand was subjected to a major windthrow event (the remnants of Hurricane Hugo in 1989 resulted in a major disturbance). The majority of the large red spruce were either uprooted or snapped, leaving a very sparse canopy. The oldest remaining red spruce at the site was determined to be 193 years of age using annual ring count. By contrast, the red spruce at McGowan Mountain appeared to be a second-growth stand that had regenerated following a severe disturbance. The oldest red spruce in this stand was determined to 67 years of age. The Cranberry study site is a mature stand, which appears to have experienced a minimal amount of disturbance. The oldest red spruce at this site was determined to be 204 years of age. The differences between these sites provide an interesting opportunity to compare the dynamics of red spruce within the context of three distinctive ecological situations.

Despite these different ecological circumstances, certain characteristics were comparable between sites. The total basal area per hectare for all species was fairly similar between sites and ranged from $42.99 \mathrm{~m}^{2} /$ ha at Turkey Run to $44.85 \mathrm{~m}^{2} /$ ha at McGowan Mountain (Table 24). The density of all tree species among sites ranged from 1800 trees per hectare at the Cranberry site to 2470 trees per hectare at Turkey Run (Table 24). These basal areas and densities agree with other surveys of central Appalachian stands (Pauley 1989, Stephenson and Clovis 1983). The higher tree densities at Turkey Run and McGowan Mountain were consistent with expectations given the extent and frequency of disturbances at these sites when compared to the Cranberry site (even though these differences were not statistically significant). 
Table 24. Site summaries for all species and for red spruce from the 2003 - 2004 samples.

\begin{tabular}{lccccccc}
\hline \multicolumn{1}{c}{ Site } & $\begin{array}{c}\text { Basal Area } \\
\mathbf{m}^{2} / \text { ha }\end{array}$ & $\begin{array}{c}\text { Density } \\
\text { trees/ha }\end{array}$ & $\begin{array}{c}\text { Relative } \\
\text { Density }\end{array}$ & $\begin{array}{c}\text { Relative } \\
\text { Basal Area }\end{array}$ & IV & H' & E \\
\hline \multicolumn{7}{c}{ All Tree Species } \\
Turkey & $42.99 \pm 2.5$ & $2470 \pm 873$ & - & - & - & 1.9 & 0.8 \\
McGowan & $44.85 \pm 2.2$ & $2257 \pm 629.4$ & - & - & - & 1 & 0.6 \\
Cranberry & $43.36 \pm 1.4$ & $1800 \pm 804$ & - & - & - & 1.4 & 0.6 \\
\multicolumn{70}{c}{ Red Spruce Trees } \\
Turkey & $5.51 \pm 5.9$ & $1310 \pm 1013$ & 53 & 12.8 & 33 & - & - \\
McGowan & $17.54 \pm 18.0$ & $1414 \pm 636$ & 62.7 & 39.1 & 51 & - & - \\
Cranberry & $12.91 \pm 15.6$ & $786 \pm 620$ & 43.7 & 29.8 & 37 & - & - \\
\hline
\end{tabular}

Current red spruce basal area ranged from $5.51 \mathrm{~m}^{2} /$ ha at Turkey Run to $17.54 \mathrm{~m}^{2} / \mathrm{ha}$ at the McGowan Mountain stand. The density of red spruce trees ranged from 786 trees per hectare at the Cranberry stand to 1414 trees per hectare at McGowan Mountain. Although this was a twofold difference ANOVA failed to detect a significant difference between stands for density at the 0.05 level. The relative density of red spruce ranged from $43.7 \%$ at the Cranberry site to $62.7 \%$ at McGowan Mountain. The relative basal area of red spruce ranged from $12.8 \%$ to $39.1 \%$, again there was no detectable difference at the $\alpha=0.05$ level. Importance values for red spruce were not significantly different between sites at the $\alpha=0.05$ level. The importance values ranged from 32.9 to 50.9 .

Thirteen tree species were encountered in the survey of the three sites. Five species, representing 38.5\% of the total species, were present at all three sites (Table 25). Seven species, accounting for $53.8 \%$ of the total species, occurred in at least two sites. The Cranberry and McGowan Mountain stands were the most similar based on the presence/absence of tree species. Together they contained nine species and $66.7 \%$ of these species were present at both sites. All of the species present at the Cranberry and McGowan stands were shade tolerant, with the exception of yellow birch whose shade tolerance is rated as intermediate. The Turkey Run site was set apart from the other by the occurrence four species that were unique to that site. These species included black cherry (shade intolerant), cucumber magnolia, and red oak (both intermediate shade tolerance), and serviceberry (shade tolerant). The occurrence of these unique species at Turkey Run were attributed to the severity and relatively short time since disturbance 
which created growing space that could be captured by a variety of species possessing a wide range of ecological attributes. Despite the greater diversity of tree species at Turkey Run, all the trees encountered in this survey are common associates in red spruce forest communities of the central Appalachians (Schuler et al 2002, Mayfield 1997, Bailey and Ware 1990, Adams and Stephenson 1989, Pauley 1989, Stephenson and Clovis 1983, Clovis 1979).

Table 25. Presence (1) - Absence (0) of tree species at the three sites.

\begin{tabular}{lcccc}
\hline \multicolumn{1}{c}{ Species } & Cranberry & McGowan & Turkey \# of Sites \\
\hline American beech & 1 & 1 & 1 & 3 \\
e. hemlock & 1 & 1 & 1 & 3 \\
red maple & 1 & 1 & 1 & 3 \\
red spruce & 1 & 1 & 1 & 3 \\
yellow birch & 1 & 1 & 1 & 3 \\
mt. holly & 1 & 1 & 0 & 2 \\
striped maple & 1 & 0 & 1 & 2 \\
mt. maple & 1 & 0 & 0 & 1 \\
sugar maple & 1 & 0 & 0 & 1 \\
black cherry & 0 & 0 & 1 & 1 \\
cuc. magnolia & 0 & 0 & 1 & 1 \\
red oak & 0 & 0 & 1 & 1 \\
serviceberry & 0 & 0 & 1 & 1 \\
\hline \multicolumn{1}{c}{ Sum } & 9 & 6 & 10 & \\
\hline \multicolumn{5}{c}{}
\end{tabular}

The diameter distributions for each site when prepared for all species and all size classes ( $\geq 2.5 \mathrm{~cm}$ ) exhibited reverse J-shaped distributions (Figure 29). Pauley (1989) and Mayfield (1997) also found this pattern in their surveys of central Appalachian spruce stands. This pattern is indicative of multicohort stands or single-cohort, multispecies, stratified stands. Mixed stands subjected to severe erratic disturbances may develop into complex species mixtures, fragments of stratified mixtures, age classes or cohorts (Fajvan and Seymour, 1993). These situations could result in several, if not all, of the stages of stand development occurring concurrently within an individual stand (Smith et al., 1997). This seems to be the case at the Turkey Run study site. 


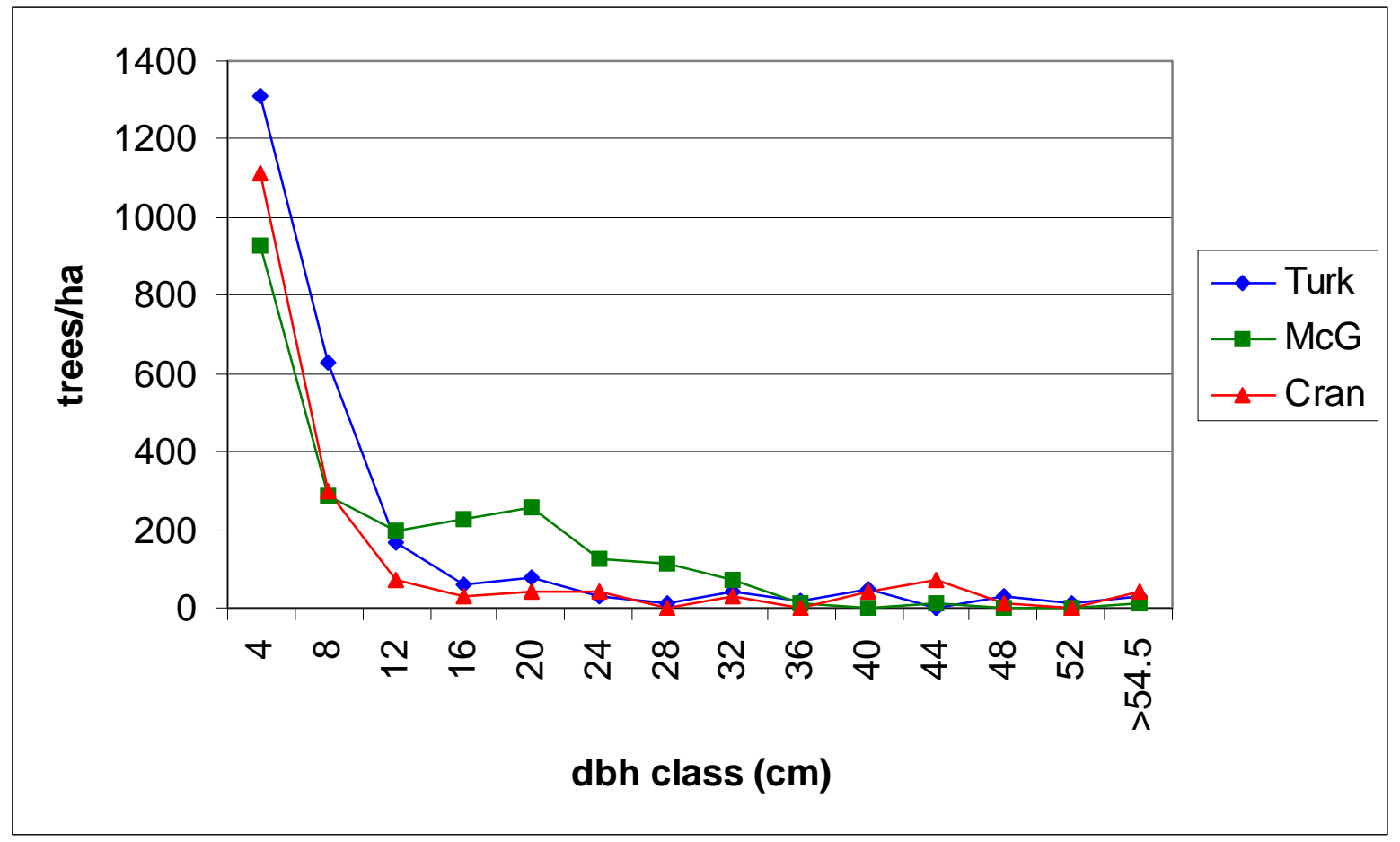

Figure 29. Diameter Distributions for all Species by Site. Turk = Turkey Run, McG = McGowan Mountain; Cran = Cranberry Site.

Turkey Run was the most diverse site. The calculated Shannon-Wiener Diversity Index $\left(\mathrm{H}^{\prime}\right)$ was 1.85 (Table 7). This was not surprising as a result of the early stages of stand development represented within the site. Large canopy gaps created by hurricane Hugo made growing space available. Several species of hardwoods and red spruce have established within these gaps. The McGowan mountain site had the lowest diversity $\left(\mathrm{H}^{\prime}=1.03\right)$. This stand is at a stage of development intermediate between the other stands. The lower diversity may be explained by red spruce successfully out-competing hardwood species as stem exclusion occurs. The Cranberry stand maintains a diversity intermediate between Turkey Run and McGowan Mountain. This may be attributed to a history of small canopy gaps created by damaged crowns or individual tree mortality. These openings would have allowed a few individuals to become established within these gaps.

The diversity of the sapling stratum varied among sites. The Cranberry site was the most diverse containing seven species, followed by Turkey Run with five species while McGowan Mountain had only two sapling species. The sapling strata at all the sites were composed almost 
exclusively of shade tolerant species. The proportions of sapling species at Turkey Run and Cranberry were similar to the proportions of their tree stratum counterparts. Red spruce was clearly the dominant species represented in the sapling strata. ANOVA was performed for red spruce sapling density, red spruce importance values, and hardwood sapling densities between sites, however no significance between sites was detected for these variables.

The shrub stratum was varied by site. Great rhododendron was common at McGowan Mountain and Turkey Run, which were both sites in early stages of stand development.

Rhododendron was absent from the more mature stand at Cranberry.

The ground cover consisted of three unifying types, bryophytes, ferns, and coarse woody debris. White wood sorrel (Oxalis montana) and partridge berry (Mitchella repens) were present at both the Turkey Run and Cranberry sites both with a greater degree of cover at the Cranberry site. Although they represent a small fraction of cover they are noteworthy due to the fact that they were common to the two sites. These two sites represent more mature red spruce stands in two distinctly different ecological situations with respect to the frequency and extent of disturbance events. These herbaceous species may rely on microenvironmental conditions created in mature spruce stands. Thus the less disturbed Cranberry site may be more suitable to these species. The recent disturbance at the Turkey Run site may have altered the site so that it is no longer optimal for these species. Their exclusion from the McGowan Mountain site may be related to the relatively young condition of that stand. 


\section{Temporal Patterns in Red Spruce Across Sites and Transects}

In spite of the fact that the successional stages of the sites varied widely, the general trend for the tree stratum at all sites over time was that of increasing importance of red spruce, while hardwood species experienced a decline. The degree of decline in relative density for hardwoods seemed to mirror the increase of red spruce relative density. This increasing pattern of red spruce relative density suggests that recruitment of red spruce has been successful and spruce ingrowth is competing with hardwoods when growing space was made available. The lower degree of increase at the Cranberry site is explained by the absence of appreciable disturbance to create new growing space.

The relative basal area of red spruce has increased at all sites. This further supports the notion that red spruce is gaining dominance at all the sites. The Turkey Run site is much more disturbed, notably with mortality of hardwoods, allowing significantly more light and growing area to support a greater rate of basal area increase of the residual red spruce. By contrast, the overall decrease in basal area at Cranberry is due to single tree mortality of dominant canopy red spruces.

The changes in the sapling stratum did not show a consistent pattern although, the density of red spruce saplings showed a slight decrease over time. The decreasing densities experienced at Turkey Run and McGowan Mountain do not necessarily indicate mortality. The temporal gains in red spruce trees during the same time periods for these sites suggests that decreasing red spruce sapling densities at these sites can be attributed to ascension from the sapling class into the tree class.

The densities for hardwood saplings experienced a decline at all sites over time. But these data suggest that mortality of hardwood saplings is occurring since additional hardwoods do not appear to be growing into the tree size class at two of the sites. By contrast, the Cranberry site, which saw the largest net decrease in sapling stems over time, realized a slight increase in hardwood tree stems (Figure 13). This suggests that some hardwood stems are surviving into tree size at this site, however at a much lower rate compared to spruce.

Data from this study show a general increase in red spruce seedlings at all sites in the largest size class. The transitional sapling class does not show a clear pattern over time, probably reflecting movements of individuals in and out of this class. The general increases in 
density, basal area, and importance of spruce in the tree class imply that spruce seedlings are progressing through the sapling class to become trees. In turn, the gains in spruce are mirrored by losses in hardwoods.

\section{$\underline{\text { Trends by Forest Zones }}$}

The greatest contrasts were found between the comparison of the red spruce and hardwood zones (Table 17) at all sites. This is not surprising since the ecotone represents an area where the two forest zones blend together. The Cranberry site showed significant differences more frequently between all zones. On the basis of red spruce and hardwood importance values in the tree stratum, all three forest zones were found to be statistically different at the Cranberry site. The forest zones were not as well differentiated at the McGowan mountain site compared to the other sites. When the data for the forest zones were pooled across sites the variables of red spruce and hardwood relative density and importance value resulted in statistically significant differences between the three forest zones.

The density of red spruce saplings was greater (not significantly) in the ecotone zone, however red spruce sapling importance values were significantly higher in the ecotone compared to the other zones. In contrast, Mayfield (1997) found that red spruce sapling densities were lowest in the hardwood zone (957 stems/ha) and greatest in the red spruce zone (19432 stems/ha). Hardwood importance values showed a significant decrease in the ecotone zone. Similarly red spruce seedlings obtained the greatest densities and importance values in the ecotone. The seedling densities recorded by Mayfield (1997) were similar in magnitude to this study with respect to the hardwood zone (Mayfield =667/ha; this study $=714 / \mathrm{ha}$ ) and the ecotone zone (Mayfield $=6351 /$ ha; this study $=7000 /$ ha). However, Mayfield found the red spruce zone to harbor 19000 more red spruce seedlings per hectare than this present study.

\section{Temporal Patterns by Forest Zone}

Mielke et al. (1986) determined that 33\% of the red spruce volume in West Virginia was dead or declining. However, the red spruce forest zone was the most stable in this survey. The 
basal area for red spruce did not change dramatically. Some mortality of individual trees, has occurred in the spruce zones however the density and in-growth of red spruce trees has offset these losses. All variables for red spruce in the tree stratum of the red spruce zone showed increasing values over time. This trend is mirrored by the loss of density from the hardwood stratum. Red spruce in the sapling stratum experienced a slight decline in density. This appears to be due ascension from the sapling class into the tree class. Red spruce seedlings have also shown increasing densities and importance in the red spruce zone.

The ecotone in this study is the transitional zone between the hardwood and red spruce forest types. Ecotones commonly exhibit a higher biodiversity than the two adjacent communities (Risser, 1993) due to the gradual transition and blending of species from one forest type to the other. Ecotones have been proposed to be a good area to study the dynamics of contrasting forest types (Noble, 1993). The density and relative density of red spruce trees increased significantly in the ecotone zone, while the relative density of hardwood trees decreased significantly. This pattern of decreasing hardwoods and increasing red spruce suggests that red spruce is expanding its range by moving into the ecotone. Red spruce saplings are remaining fairly static over time, while red spruce seedlings are increasing. This suggests that red spruce seedlings are consistently surviving into the sapling strata and furthermore growing into the tree stratum at a rate that is facilitating the spread of the red spruce zone into the ecotone.

The hardwood zone in this study has experienced an increase in the density of red spruce trees. The relative density of red spruce trees in the hardwood zone has increased significantly, while the relative density of hardwood species has decreased significantly. The hardwood zone has seen little change in the density of red spruce saplings and seedlings. The data suggest that red spruce seedlings are progressing into saplings and that some of these individuals are surviving into the tree class.

Temporal studies of the spruce forest type divided by forest zone were not found. However, temporal studies of the spruce forest type in generally sparse. As elucidated above the overall temporal trends in the present study has revealed increasing red spruce density and to a smaller extent red spruce dominance. This study did not reveal the mortality documented in other studies. Siccama et al (1982) found 50\% decrease in red spruce density and basal area over 15 years, while Scott et al (1984) found red spruce basal area reductions of $60 \%$ to $70 \%$ from the 
early 1960’s to 1982. Silver et al (1991) reported a significant increase in the number of dead red spruce trees from $26.1 \%$ to 36.7 \% over a five-year period. This phenomenon of high mortality rates was not apparent in this study.

The relative density of red spruce has increased across all of the forest zones (Figure. 30). My data suggest that the red spruce community is advancing throughout the forest zones. This trend of increasing density of red spruce should eventually lead to an increase in red spruce dominance (basal area) over time, within each of the forest zones.

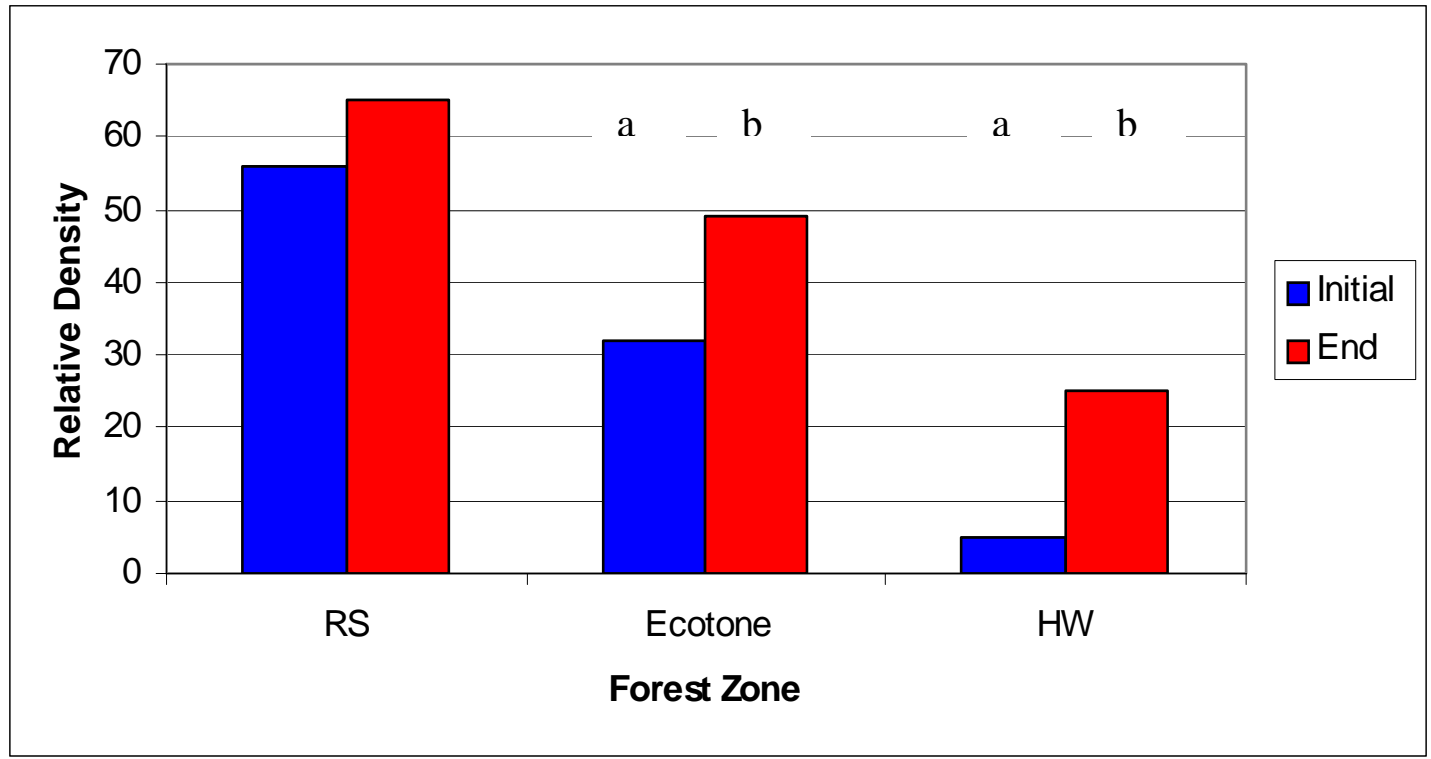

Figure 30. The change in the relative density of red spruce over time by forest zone. Bars with different letters indicate the change was statistically significant.

\section{$\underline{\text { Conclusions }}$}

The red spruce communities in this study are experiencing an increasing density of red spruce over time. This increase is occurring across all forest zones. Red spruce is becoming successfully established and expanding into the ecotone and the hardwood canopy of the hardwood forest zone. The sites in this study represented three distinct ecological situations. The greatest increase of red spruce was seen in the more disturbed and earlier successional sites (Turkey Run and McGowan Mountain). The less disturbed red spruce community at Cranberry experienced the least change. Instead of declining, red spruce populations in this study are 
actually thriving and increasing in density of seedlings, advanced regeneration and trees across the spruce-hardwood ecotone as well as under the surrounding hardwood canopy. Red spruce seedling densities are greater with increased cover of bryophytes and coarse woody debris, while densities are reduced with increasing cover of Dryopteris spp. 


\section{Literature Cited}

Adams, H.S., and S.L. Stephenson 1994. An ecological analysis of the red spruce/northern hardwood ecotone in the Allegheny mountains of West Virgina. Proceedings of the West Virginia Academy of Sciences 65: 4-5.

Adams, H.S., and S.L. Stephenson, 1989. Old-growth red spruce communities in the mid-Appalachians. Vegetatio 85; 45-56.

Adams, H.S., S.L. Stephenson, T.J. Blasing, and D.N. Duvick, 1985. Growth-trend declines of spruce and fir in mid-Appalachian subalpine forests. Environmental and Experimental Botany 25(4): 315-325.

Allard, H.A., and E. C. Leonard, 1952. The Canaan and the Stony river valleys of West Virginia, Their former magnificent spruce forests, their vegetation and floristics today. Castanea 17(1); 1.

Baldwin, H.I., 1933. The density of spruce and fir reproduction related to the direction of exposure. Ecology 14(2); 152-156.

Bailey, C.M., and S. Ware. 1990. Red spruce forests of Highland County, Virginia: biogeographical considerations. Castanea 55(4); 245-258.

Burns, R.M., and B.H. Honkala, 1990. Silvics of North American: 1. Conifers. Agriculture Handbook 654. US Dept. of Agriculture, Forest Service, Washington D.C., Vol. 2, 899 p.

Clarkson, R.B. 1964. Tumult on the mountains: lumbering in West Virginia: 1770-1920. McClain Printing, Parsons, WV. 410 p.

Clovis, J.F. 1979. Tree importance values in West Virginia red spruce forests inhabitated by the Cheat Mountain Salamander. Proc W Va Acad. Sci. 51; 58-64.

Darlington, H.C., 1943. Vegetation and Substrate of Cranberry Glades, West Virginia. Botanical Gazette 104:371-393.

Dibble, A.C., J.C. Brissette, and M.L. Hunter Jr. 1999. Putting community data to work: some understory plants indicate red spruce regeneration habitat. Forest Ecology and Management 114: 257-291.

Eagar, C., and M.B. Adams, editors 1992. Ecology and decline of red spruce in the Eastern United States. Springer-Verlag. New York, N.Y. 
Fajvan, M.A., and R.S. Seymour 1993. Canopy stratification, age structure, and development of multicohort stands of eastern white pine, eastern hemlock, and red spruce. Canadian Journal of Forest Research 23: 1799-1809.

Frank, R.M., and J.C. Bjorkbom, 1973. A silvicultural guide for spruce-fir in the northeast. FS GTE NE-6, 15pp.

Fulling, E. H. 1936. Abies intermedia, the Blue Ridge fir, a new species. Journal of the Southern Appalachian Botanical Club 1:91-94.

Geballe, G.T., W.H. Smith, and P.M. Wargo 1990. Red spruce seedling health: an assessment of acid fog deposition and heavy metal soil contamination as interactive stress factors. Can. J. For. Res. 20: 1680-1683.

Greenwood, M., and D. McConville 2002. Factors affecting the regeneration of red spruce and balsam fir. Cooperative Forestry Research Unit Annual Report 2001-2002 37-40.

Griffith, D.M., and R.H. Widmann, 2003. Forest Statistics for West Virginia: 1989 and 2000. USDA Forest Service Resource Bulletin NE-157, Newtown Square, PA.

Hadley, J.L., and R.G. Amundson 1992. Effects of radiational heating at low air temperature on water balance, cold tolerance, and visible injury of red spruce foliage. Tree Physiology 11(1): 1-17.

Hamburg, S.P., and C.V. Cogbill 1988. Historical decline of red spruce populations and climatic warming. Nature 331: 428-431.

Harrington, T.C. 1986. Growth decline of wind-exposed red spruce and balsam fir in the White Mountains. Can. J. For. Res. 16: 232-238.

Hicks, R.R. Jr. and D.A. Mudrick, 1994. 1993 forest health: a status report for West Virginia. West Virginia Department of Agriculture, Charleston, WV. 68 p.

Hornbeck, J.W., and R.B. Smith, 1985. Documentation of red spruce growth decline. Canadian Journal of Forest Research 15; 1199-1201.

Hughes, J.W., and D.A. Bechtel, 1997. Effect of distance from forest edge on regeneration of red spruce and balsam fir in clearcuts. Canadian Journal of Forest Research 27: 20882096.

Jacobson, G. L., Jr., T. Webb, III, and E. C. Grimm, 1987. Patterns and rates of vegetation change during the deglaciation of eastern North America, in Ruddiman, W.F., and H. E. Wright eds, North America and adjacent oceans during the last deglaciation. Boulder, CO, Geological Society of America. The Geology of North America, v. K-3. 
Johnson, A.H., E.R. Cook, and T.G. Siccama 1988. Climate and red spruce growth and decline in the northern Appalachians. Proceedings of the National Academy of Sciences of the United States of America 85(15): 5369-5373.

Korstian, C.F. 1937. Perpetuation of spruce on cut-over and burned lands in the higher southern Appalachian mountains. Ecological Monographs 7(1): 126-167.

LeBlanc, D.C. 1990. Red spruce decline on Whiteface Mountain, New York. I. Relationships with elevation, tree age, and competition. Can. J. For. Res. 20: 1408-1414.

LeBlanc, D.C., and D.J. Raynal 1990. Red spruce decline on Whiteface Mountain, New York. II. Relationships between apical and radial growth decline. Can. J. For. Res. 20: 14151421.

Mayfield, A.E. III., 1997. Distribution and abundance of red spruce regeneration across spruce-hardwood ecotones at Gaudineer Knob, West Virginia. MS Thesis, West Virginia University, Morgantown. 112pp.

McIntosh, R. P. and R. T. Hurley, 1964. The spruce-fir forests of the Catskill mountains. Ecology 45(2): 314-326.

McLaughlin, S.B., C.P. Andersen, N.T. Edwards, W.K. Roy, and P.A. Layton 1990. Seasonal patterns of photosynthesis and respiration of red spruce saplings from two elevations in declining southern Appalachian stands. Can. J. For. Res. 20: 485-495.

McLaughlin, S.B., D.J. Downing, T.J. Blassing, E.R. Cook, and H.S. Adams 1987. An analysis of climate and competition as contributors to decline of red spruce in high elevation Appalachian forests of eastern United States. Oecologia 72: 487-501.

Mielke, M.E., D.C. Soctomah, M.A. Marsden, and W.M. Ciesla 1986. Decline and mortality of red spruce in West Virginia. USDA Forest Service Report 86-4.

Missel, N.D., 1999. The characterization of mid-Appalachian spruce-hardwood ecotones and their spatial and temporal dynamics. MS Thesis, Clemson University. 112pp.

Noble, I.R. 1993. A model of the responses of ecotones to climate change. Ecological Applications 3(3): 396-403.

Oliver, C. D., and B. C. Larson, 1996. Forest Stand Dynamics Update Edition. John Wiley \& Sons, Inc. USA, 520pp.

Oosting, H.J., and W.D. Billings 1951. A comparison of virgin spruce-fir forest in the northern and southern Appalachian system. Ecology 32(1): 84-103. 
Pauley, E.F. 1989. Stand composition and structure of a second-growth red spruce forest in West Virginia. Castanea 54(1): 12-18.

Rheinhardt, R.D., and S.A. Ware 1984. The vegetation of the Balsam Mountains of southwest Virginia: a phytosociological study. Bulletin of the Torrey Botanical Club 111(3); 287-300.

Risser, P.G. 1993. Ecotones: ecotones at local to regional scales from around the world. Ecological Applications 3(3): 367-368.

Roth, D.R., and T.J. Fahey, 1998. The effects of acid precipitation and ozone on the ectomycorrhizae of red spruce saplings. Water, Air, and Soil Pollution 103: 263-276.

Schuler, T.M., W.M. Ford, and R.J. Collins 2002. Successional dynamics and restoration implications of a montane coniferous forest in the central Appalachians, USA. Natural Areas Journal 22: 88-98.

Scott, J.T., T.G. Siccama, A.H. Johnson, and A.R. Breisch 1984. Decline of red spruce in the Adirondacks, New York. Bulletin of the Torrey Botanical Club 111(4): 438-444.

Smith, D.M., B.C. Larson, M.J. Kelty, and P.M.S. Ashton, 1997. The practice of silviculture. Applied Forest Ecology $9^{\text {th }}$ edition. John Wiley \& Sons, Inc. USA. 537pp.

Siccama, T.G., M. Bliss, and H.W. Vogelmann 1982. Decline of red spruce in the Green Mountains of Vermont. Bulletin of the Torrey Botanical Club 109(2): 162-168.

Silver, W.L., T.G. Siccama, C. Johnson, and A. H. Johnson 1991. Changes in red spruce populations in montane forests of the Appalachians, 1982-1987. American Midland Naturalist 125: 340-347.

Stephenson, S. L. and H. S. Adams, 1986. An ecological study of balsam fir communities in West Virginia. Bulletin of the Torrey Botanical Club 113(4): 372-381.

Stephenson, S. L. and H. S. Adams, 1984. The spruce-fir forest on the summit of Mount Rogers in southwestern Virginia. Bulletin of the Torrey Botanical Club 111(1): 69-75.

Stephenson, S.L., and J.F. Clovis, 1983. Spruce forests of the Allegheny Mountains in central West Virginia. Castanea 48(1); 1-12.

Strausbaugh, P.D., and E.L. Core, 1977. Flora of West Virginia, second edition. Seneca Books, Inc. Morgantown, West Virginia.

Tritton, L.M., and T.G. Siccama, 1990. What proportion of standing trees in forests of the northeast are dead. Bulletin of the Torrey Botanical Club 117(2); 163-166. 
USDA, NRCS. 2004. The PLANTS Database, Version 3.5 (http://npdc.usda.gov/). National Plant Data Center, Baton Rouge, LA 70874-4490 USA.

U.S. Geological Survey, 1999, Digital representation of "Atlas of United States Trees" by Elbert L. Little, Jr. http://climchange.cr.usgs.gov/data/atlas/little/

Waite, C.E., D.H. DeHayes, J. Rebbeck, G.A. Schier, and A.H. Johnson 1994. The influence of elevated ozone on freezing tolerance of red spruce seedlings. New Phytol. 126: 327-335.

Watts, W.A. 1979. Late Quaternary vegetation of central Appalachia and the New Jersey coastal plain. Ecological Monographs 49(4): 427-469.

Wu, Xinyuan, J.F. McCormick, and R.T. Busing, 1999. Growth pattern of Picea rubens prior to canopy recruitment. Plant Ecology 140: 245-253. 